\title{
Distributed Utility Technology Cost, Performance, and Environmental Characteristics
}

Yih-huei Wan and Steve Adelman

National Renewable Energy Laboratory 1617 Cole Boulevard Golden, Colorado 80401-3393

A national laboratory of the U.S. Department of Energy Managed by Midwest Research Institute under Contract No. DE-AC36-83CH10093

Prepared under Task No. AS819401

June 1995 


\section{NOTICE}

This report was prepared as an account of work sponsored by an agency of the United States government. Neither the United States government nor any agency thereof, nor any of their employees, makes any warranty, express or implied, or assumes any legal liability or responsibility for the accuracy, completeness, or usefulness of any information, apparatus, product, or process disclosed, or represents that its use would not infringe privately owned rights. Reference herein to any specific commercial product, process, or service by trade name, trademark, manufacturer, or othenwise does not necessarily constitute or imply its endorsement, recommendation, or favoring by the United States government or any agency thereof. The views and opinions of authors expressed herein do not necessarily state or reflect those of the United States government or any agency thereof.

Available to DOE and DOE contractors from:

Office of Scientific and Technical Information (OSTI)

P.O. Box 62

Oak Ridge, TN 37831

Prices available by calling (615) 576-8401

Available to the public from:

National Technical Information Service (NTIS)

U.S. Department of Commerce

5285 Port Royal Road

Springfield, VA 22161

(703) $487-4650$ 


\section{Preface}

Distributed Utility (DU) is an emerging concept in which modular generation and storage technologies sited near customer loads in distribution systems and specifically targeted demand-side management programs are used to supplement conventional central station generation plants to meet customer energy service needs. Research has shown that implementation of the DU concept could provide substantial benefits to utilities. This report summarizes the cost, performance, and environmental and siting characteristics of existing and emerging modular generation and storage technologies that are applicable under the DU concept. It is intended to be a practical reference guide for utility planners and engineers seeking information on DU technology options. This work was funded by the Office of Utility Technologies of the U.S. Department of Energy.

Approved for the

NATIONAL RENEWABLE ENERGY LABORATORY

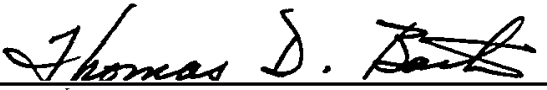

Thomas D. Bath, Director Analytic Studies Division

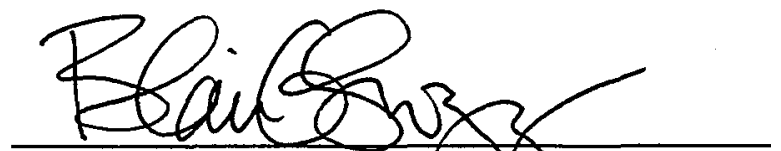

Blair G. Swezey, FWP Tdsk Manjpger Market Analysis Branch 


\section{Executive Summary}

The purpose of this study is to provide pertinent information on selected distributed utility (DU) technologies that planners and engineers need to evaluate DU implementations in electric systems. It is intended to serve as a practical reference guide for utility planners and engineers by having the necessary performance and cost information in one place.

In the DU concept, modular generation and storage technologies sited near customer loads in the distribution systems and specifically targeted demand-side management (DSM) programs are used to supplement the conventional central station generation plants to meet the customers' energy service needs. The distributed generation and storage systems and targeted DSM measures can satisfy some of the needs for new generation sources, as well as regional transmission and local distribution system expansions. In selected locations, implementation of the DU concept could help improve feeder load factor, enhance service reliability, provide local voltage support, delay or eliminate costly distribution upgrades, and lower line losses. The value of such distributed applications could be significantly higher than the energy and capacity credits typically ascribed to these technologies. The DU concept gives utilities more flexibility to adapt to changing local conditions and needs. It could also offer an early market-entry path for cost-effective applications of some emerging technologies.

The Electric Power Research Institute, National Renewable Energy Laboratory, and Pacific Gas \& Electric Company started the Distributed Utility Valuation (DUV) project in 1992. The objectives of this government/industry collaborative effort were to test the hypothesis that the DU concept would be economical and technically feasible, and to develop planning models and valuation methodologies for utilities to incorporate the concept into their planning processes. The DUV project team published a monograph summarizing major issues and basic research needs related to DU implementations. One issue identified in the monograph was the lack of consistent DU technology performance and cost data for planners and engineers to evaluate DU applicabilities in specific utility systems. This report summarizes the results of a DUV project task that examined the cost and performance characteristics of existing and emerging modular generation and storage technologies applicable to DU settings. Environmental characteristics of these modular generation and storage technologies and their siting considerations under current environmental and permitting regulations are discussed. Actual siting experiences of several distributed generation and storage systems are also included to highlight the technology attributes and to show potential obstacles during siting and permitting processes.

The DU technology options included in this report are either already commercially available or have nearterm commercial potential. Supply-side DU technology options covered are engine/generator sets, turbine/generator sets, photovoltaics, solar thermal dish-Stirling systems, wind turbines, fuel cells, and battery storage systems. Many commonly used DSM technologies are included as examples of demandside DU options.

Current technology performance and cost information is provided for utilities to analyze DU options to meet the demands of customers and solve system problems in the near term. Projected or hypothetical cost and performance information is included for use in evaluating the long-term potential of competitive strategies. The latter can be used in DU planning models currently under development under other DUV project tasks or in other utility planning models. The general information provided in this report will not meet the specific data needed for actual siting and installation of a particular technology option. For further information, refer to the reference list included at the end of the report. 
The applicability and cost-effectiveness of any DU technology depend on its value to the utility system. The values or benefits, including energy and capacity credits, capital expenditure deferrals, loss savings, and service reliability and quality enhancements are location- and utility-specific. They are functions of utility planning assumptions and valuation methodologies. Individual analysis must be performed to determine these values. In addition, implementation of DU technologies involves other institutional and regulatory issues, such as how to distribute these benefits in a more competitive utility market. These issues should be investigated in future efforts. They are not addressed here. 


\section{Contents}

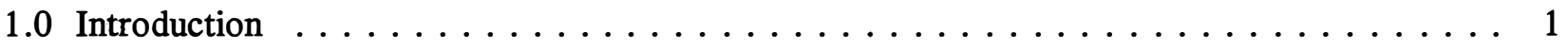

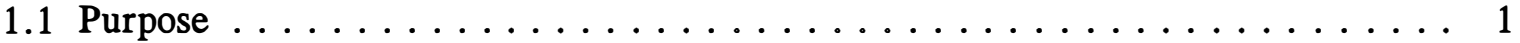

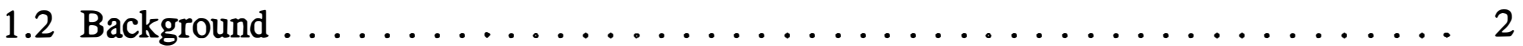

1.3 Distributed Utility Concept $\ldots \ldots \ldots \ldots \ldots \ldots \ldots \ldots \ldots \ldots \ldots$

1.4 Distributed Utility Technologies $\ldots \ldots \ldots \ldots \ldots \ldots \ldots \ldots \ldots \ldots$

2.0 Supply-Side Distributed Utility Technology Options $\ldots \ldots \ldots \ldots \ldots \ldots \ldots$

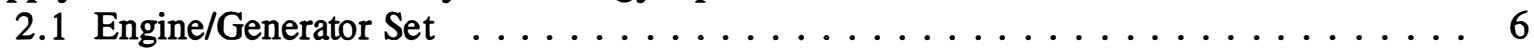

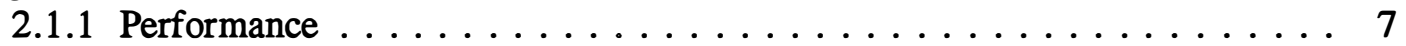

2.1.2 Status of Technology $\ldots \ldots \ldots \ldots \ldots \ldots \ldots \ldots \ldots$

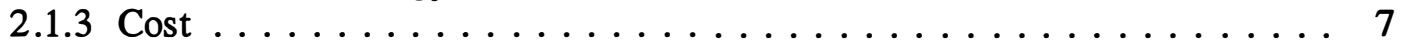

2.2 Gas Turbine/Generator Sets $\ldots \ldots \ldots \ldots \ldots \ldots \ldots \ldots \ldots \ldots$

2.2 .1 Performance $\ldots \ldots \ldots \ldots \ldots \ldots \ldots \ldots \ldots \ldots \ldots$

2.2.2 Status of Technology $\ldots \ldots \ldots \ldots \ldots \ldots \ldots \ldots \ldots$

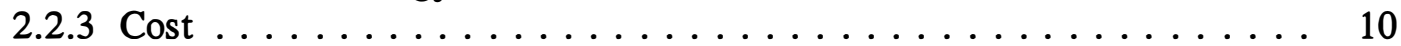

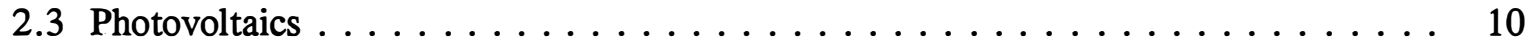

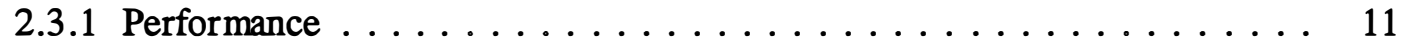

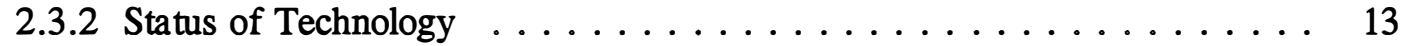

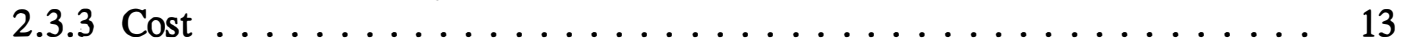

2.4 Wind Energy System $\ldots \ldots \ldots \ldots \ldots \ldots \ldots \ldots \ldots \ldots \ldots \ldots \ldots$

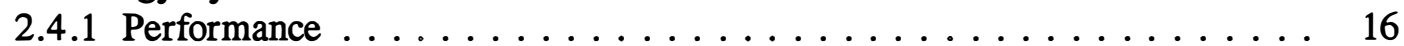

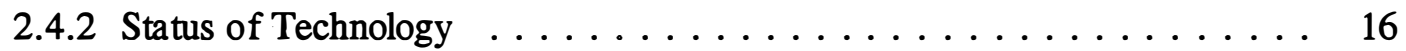

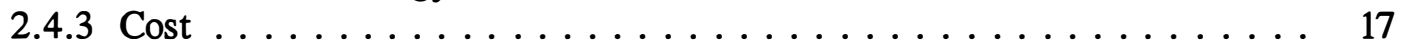

2.5 Battery Storage System $\ldots \ldots \ldots \ldots \ldots \ldots \ldots \ldots \ldots \ldots \ldots \ldots \ldots \ldots$

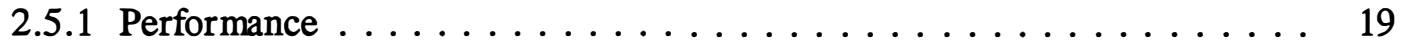

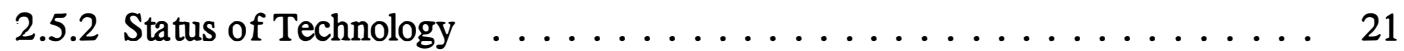

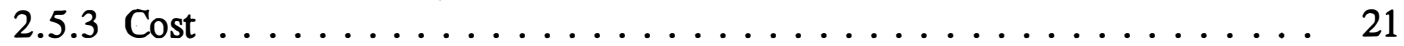

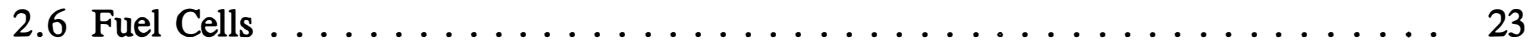

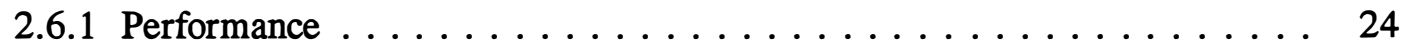

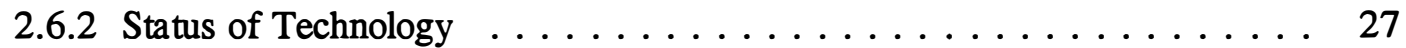

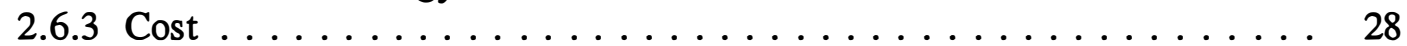

2.7 Parabolic Dish Solar Thermal Generating System . . . . . . . . . . . . . . 29

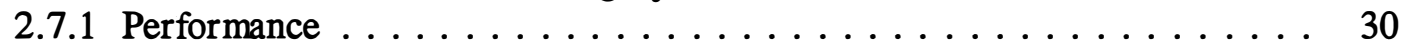

2.7.2 Status of Technology $\ldots \ldots \ldots \ldots \ldots \ldots \ldots \ldots \ldots \ldots \ldots \ldots \ldots$

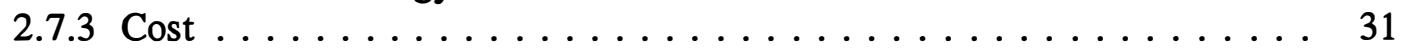

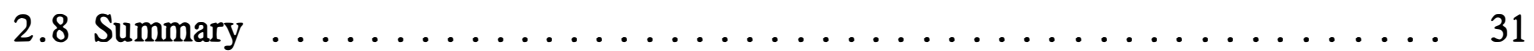

3.0 Demand-Side Distributed Utility Technology Options $\ldots \ldots \ldots \ldots \ldots \ldots \ldots \ldots$

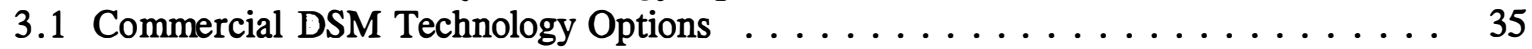

3.1 .1 Efficient HVAC Options $\ldots \ldots \ldots \ldots \ldots \ldots \ldots \ldots \ldots \ldots \ldots$

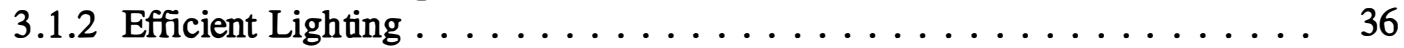

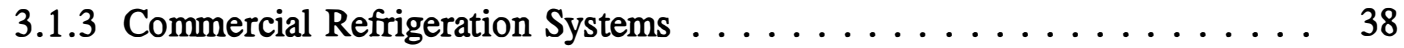

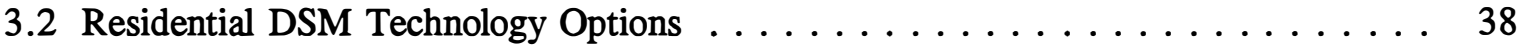

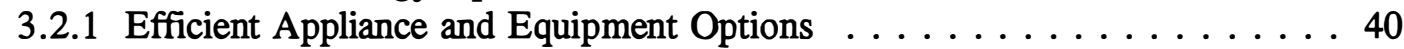

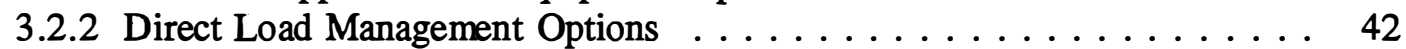

3.3 Industrial DSM Technology Options $\ldots \ldots \ldots \ldots \ldots \ldots \ldots \ldots \ldots \ldots$ 
4.0 Environmental Characteristics and Siting Considerations $\ldots \ldots \ldots \ldots \ldots \ldots$

4.1 Summary of Environmental Regulations Affecting DU Technologies . . . . . . . . 44

4.1 .1 Federal Regulations . . . . . . . . . . . . . . . . . . 44

4.1.2 State Environmental Regulations . . . . . . . . . . . . . . . 46

4.1 .3 Local Environmental Regulations . . . . . . . . . . . . . . . . . 46

4.1 .4 Additional Siting Constraints . . . . . . . . . . . . . . 47

4.2 Brief Environmental Analysis of Selected DU Technologies . . . . . . . . . . 47

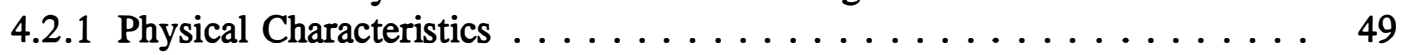

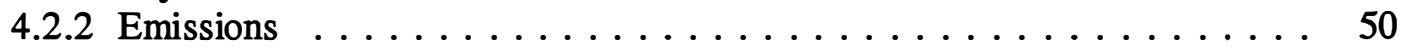

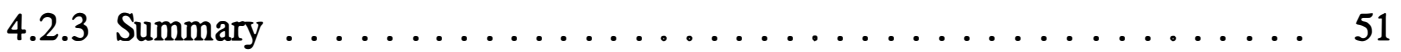

4.3 Siting Examples . . . . . . . . . . . . . . . . . . 52

4.3.1 The Chino Battery Energy Storage Plant . . . . . . . . . . . . 52

4.3.2 Sacramento Municipal Utility District Distributed Generation ONSI Fuel Cell . . . . . . . . . . . . . . . . . . 53

4.3.3 South Coast Air Quality Management District ONSI Fuel Cell . . . . . . 53

4.3.4 PG\&E Company 500-kW Photovoltaic Distributed Generation Plant . . . . 53

4.3.5 Santa Clara Demonstration Group 2-MW Molten Carbonate Fuel Cell . . . 54

4.3.6 EPRI/PG\&E Collaborative DU Internal Combustion Generator Set . . . . 54

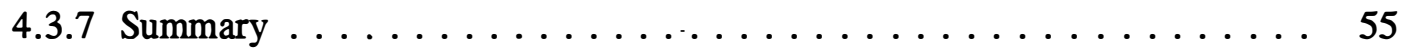

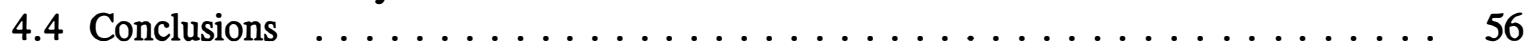

5.0 Planning and Operating Considerations $\ldots \ldots \ldots \ldots \ldots \ldots \ldots \ldots \ldots \ldots \ldots \ldots \ldots \ldots \ldots$

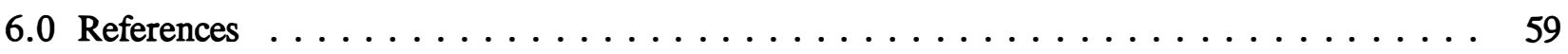

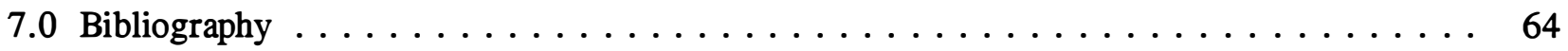

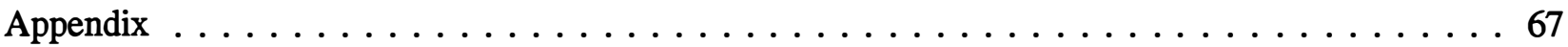




\section{List of Tables}

1-1. Selected Supply-Side DU Technologies $\ldots \ldots \ldots \ldots \ldots \ldots \ldots \ldots \ldots$

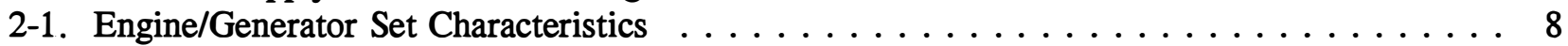

2-2. Turbine/Generator Set Characteristics $\ldots \ldots \ldots \ldots \ldots \ldots \ldots$

2-3. PV Module Costs and Performance Predictions $\ldots \ldots \ldots \ldots \ldots \ldots$

2-4. PV Balance-of-Plant Cost Forecast . . . . . . . . . . . . . . . . . . . 14

2-5. Projections for Cost and Performance of Wind Turbines . . . . . . . . . . . 18

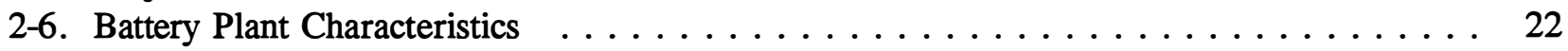

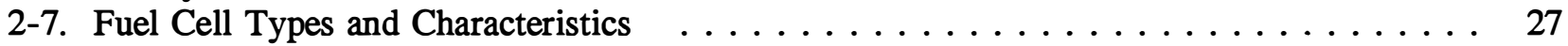

2-8. Attributes of PAFC Power Plant . . . . . . . . . . . . . . . . . . 29

2-9. Parabolic-Dish Stirling System Cost and Performance Projections . . . . . . . . . . 31

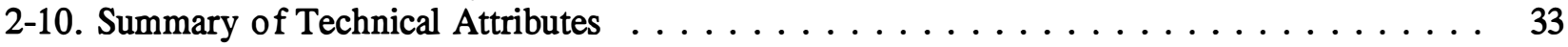

3-1. Lighting Systems . . . . . . . . . . . . . . . . . . . . . . 39

4-1. Summary of Regulatory Impacts on 11 Selected DU Technologies $\ldots \ldots \ldots$. . . . . . . 48

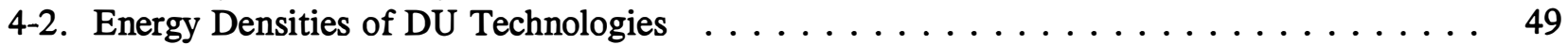

4-3. $\mathrm{NO}_{x}$ Emission Rates for $11 \mathrm{DU}$ Technologies $\ldots \ldots \ldots \ldots \ldots \ldots$

\section{List of Figures}

1. Gas turbine partial-load efficiency $\ldots \ldots \ldots \ldots \ldots \ldots \ldots \ldots \ldots$

2. Typical current-voltage characteristic curve for a $5-\mathrm{kW}$ PV array $\ldots \ldots \ldots \ldots \ldots \ldots$

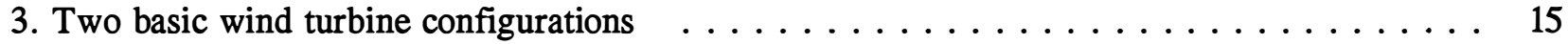

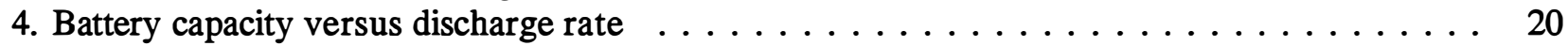

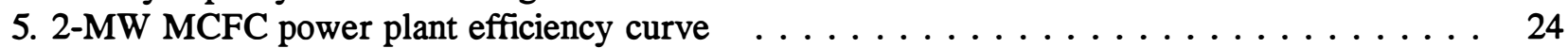

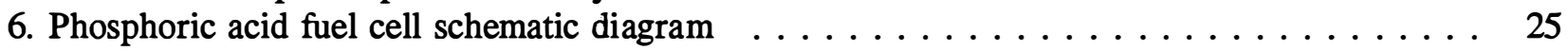

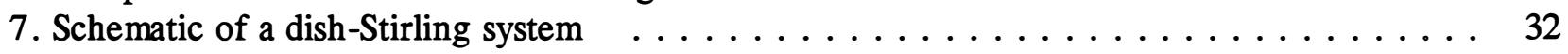




\subsection{Introduction}

\subsection{Purpose}

The purpose of this report is to document the cost, performance, and environmental characteristics-as well as related siting and permitting issues - of distributed utility (DU) technologies for utility planners and designers. It provides answers to the following questions:

(1) What are the supply- and demand-side management (DSM) technologies that are most applicable to the DU concept?

(2) What are the cost, performance and operating characteristics of the applicable DU technologies, and how are they expected to evolve over time?

(3) What are the environmental characteristics of the applicable DU technologies and what kind of siting and permitting issues are pertinent?

The technology options discussed here are either commercially available or have near-term commercial potential. This report is intended to be a practical reference guide for utility planners and engineers seeking pertinent performance and cost information on DU technology options. It provides utilities with the data they need to evaluate the feasibility of implementing DU options in their systems without initiating their own screening and data collecting tasks. The collected cost and performance information can be used in DU planning models-such as the enhanced Delta model developed by the Elecric Power Research Institute- or other utility planning models.

Current cost and performance data of DU technologies are provided for utilities to plan and design a system to meet customer demands and solve system problems in the near-term. Projected cost and performance information is also included in the report for utilities to evaluate the long-term potential of emerging technologies and competitive strategies.

Cost and performance data were taken from existing sources, including manufacturers' specifications, utility case studies, and reports by various research institutes and national laboratories. As might be expected, cost information and projections drawn from different sources are not always consistent. We attempted to reconcile such inconsistencies when feasible. However, technology performance information provided here cannot substitute for the detailed analysis needed to account for specific utility system requirements. In addition, actual siting of facilities will require site-specific information, which are not included here. Readers who need more specific technical data can refer to the reference section for additional sources of information.

The applicability and cost-effectiveness of any DU technology will depend on the benefits, or values, that it offers to the utility system. These include energy and capacity credits, capital expenditure deferrals, loss savings, service reliability and quality enhancements, all of which are functions of utility planning assumptions and valuation methodologies. Individual analysis has to be performed to determine these values. In addition, implementing DU technologies involves other institutional and regulatory issues, such as who will be allowed to capture these benefits and how to distribute these benefits in a more competitive utility market. These issues are not addressed in this report.

Section 2 of this report provides cost and performance information for supply-side DU technologies. Section 3 covers DSM technologies. Environmental and siting characteristics of selected DU technologies 
are provided in Section 4. Planning and operating considerations of DU technologies are briefly discussed in Section 5. References are given in Section 6.

\subsection{Background}

The electric utility industry today is changing in response to new developments in technology, regulatory practices, and economic conditions. Over the last 20 years, the pace of change has been quickened significantly. Some of the changes are profound. The current business environment of the electric utility industry is fundamentally different from that of a decade ago. As utilities continue to respond to the challenges and shifts in the business and economic environments, they may alter the way they conduct their business, including the way they operate, plan, and perhaps even the way they structure themselves.

By the middle 1960s, electric utilities in the United States had evolved into highly vertically integrated structures. These structures developed because, for many years, technology improvements and economies of scale had enabled larger central station generating plants to supply power at lower cost than smaller plants, and because the costs for generation greatly exceeded those for transmission and distribution. It was more economical for utilities to build a few large central station generating plants and then deliver the power through the interconnected transmission and distribution (T\&D) systems to the customers than it was to construct many small generators at the customer load centers. However, this condition began to change in the 1970s. The steady and constant load growth that had sustained the constructions of large power plants in the past slowed and became unstable. Power plant economies of scale, which improved consistently during the first 100 years of utility industry development, leveled out. On the other hand, performance of smaller-scale generating systems has improved significantly. In addition, rising T\&D costs had become an increasingly large portion of utility capital outlays. For example, total utility capital investment for T\&D has exceeded that for generation since 1988 (Edison Electric Institute 1993). This trend is projected to continue. Furthermore, the T\&D assets that account for the major portion of current and forecasted capital investment are not often utilized to their full capacities because T\&D systems are usually designed to meet infrequent but large peak loads.

The business environment of the electric utility industry was further influenced by the sudden increase of fuel prices and the subsequent high inflation during the oil crises of the 1970s, delays and cost overruns of nuclear power plants, and the growth of the environmental movement beginning in the late 1960s. The resulting electricity cost increase (in real dollars), perceived fossil fuel shortage, and environmental concerns caused changes in utility regulatory practices. The Public Utility Regulatory Policies Act of 1978 (PURPA) opened up the utility generation sector by allowing nonutility generators (NUGs) to be interconnected with and sell power to utilities. The Energy Policy Act of 1992 (EPACT) has accelerated the pace of competition. In addition to allowing a new class of exempt wholesale generators, EPACT establishes a federal policy for open access to the nation's transmission systems. Under new Federal Energy Regulatory Commission (FERC) rules designed to implement the EPACT transmission access provisions, utilities can be required to provide wholesale transmission services to third parties. Electric utilities not only face competition in the generation sector, but must also open their transmission systems to facilitate such competition.

All of these factors increase the pressures to electric utilities to reduce costs and to increase the value of their electricity services to customers. At the same time, utilities face increasingly critical regulatory reviews and public opposition to the construction of new power plants and lines. Utilities are beginning to realize that the cost of meeting customer demand through the traditional approaches of building central station power plants, transmission lines, and distribution networks may be not competitive in today's market. Utilities may have to consider other options-such as DSM programs-to meet demands. Furthermore, advancements in power generating and storage technologies may offer utilities and their 
customers potentially low-cost alternatives to traditional methods of providing service. These developments suggest that it may be economically beneficial to place modular generation or storage systems in the distribution system close to selected loads, or to target DSM programs strategically to avoid T\&D upgrades and to reduce the need for additional central station power plants. This idea of central station generation supplemented by distributed generation and storage, along with targeted DSM programs, gives rise to the distributed utility (DU) concept.

\subsection{Distributed Utility Concept}

The DU concept is one of the new ideas proposed for future utility service and structure. Under this concept, electric utilities will use distributed generation, storage, and targeted DSM technologies along with the more traditional central station power plants to provide electric service. This structure can offer significant benefits for utilities and customers alike while lowering financial, technical, environmental, and institutional risks.

In addition to their capacity and energy value benefits, modular generation and storage systems installed in distribution networks can be used to defer or eliminate $T \& D$ additions and upgrades. Being close to the load, distributed generation and storage facilities can also help reduce utility system losses. Furthermore, modular generating technologies give utilities more flexibility in capacity planning. Faced with uncertain load growth, utilities can install modular technologies in small increments to more closely match the capacity with actual demand instead of building generating plants that increase capacity by large amounts at once. The ability to plan for and react quickly to changing load conditions, rather than being locked into a scenario that may not be suitable for future variables, greatly reduces the risk for utilities.

Many case studies have shown that distributed generation, storage, and targeted DSM could provide substantial value to utilities. However, many questions must be answered before the DU concept is broadly accepted by utilities. Utilities will need DU models and planning methodologies to evaluate and quantify the benefits of such a system. Various technical concerns related to specific DU technologies must be resolved before DU can be implemented on a system-wide basis. Long-term performance and cost characteristics of many DU technologies are not well established at this time. Operation and control of DU technologies and the interface of DU technologies with existing power grids must be fully understood, as must siting, environmental impacts, and other regulatory and institutional issues. Several utilities have started DU demonstration projects to gain operating experience.

The Distributed Utility Valuation (DUV) project is a government/industry collaborative effort sponsored by the U.S. Department of Energy through the National Renewable Energy Laboratory, the Electric Power Research Institute, Pacific Gas and Electric Company, and Pacific Northwest Laboratory. Its goal is to assist the utility industry in fully evaluating the costs and benefits of implementing the DU concept. Objectives of this project include (1) development of valuation methodologies and planning models; (2) improved characterization of technical issues and research and development requirements; and (3) analyses of institutional/stakeholder issues and opportunities.

\subsection{Distributed Utility Technologies}

Generating and storage systems that appear feasible for DU applications include both established and emerging technologies. Generating systems can be conventional fossil-fueled technologies or renewable energy technologies. The emerging technologies are those that are expected to become commercially viable in the near future (1995-1998). For example, small diesel engine generators and gas-fired turbine generator sets are established, mature generating technologies that are well suited to the DU concept. Photovoltaic (PV) and wind technologies have proven their value in providing clean electric power for 
utilities in many applications. Fuel cell power plants have also been successfully installed by utilities for dispersed generating and cogenerating applications, and their performance is continually improving. Among emerging technologies, the solar thermal dish-Stirling systems hold promise for near-term commercial applications in DU settings. The battery energy storage system is another established technology suitable for DU applications, although this is not a generating technology. Other emerging energy storage technologies, such as superconducting magnetic energy storage systems and flywheels, are also aimed at the dispersed applications in utility systems. Table 1-1 lists the existing and emerging supply-side DU technologies discussed in this report.

Table 1-1. Selected Supply-Side DU Technologies

\begin{tabular}{ll}
\hline Existing Technologies & Emerging Technologies \\
\hline Engine/Generator Set & Solar Thermal Dish-Stirling System \\
Turbine/Generator Set & \\
PV & \\
Wind Energy System & \\
Fuel Cells & \\
Battery Storage System & \\
\hline
\end{tabular}

Selection of DU technologies in this report is based on the current understanding of the DU concept and benefits to utilities (DUV project monograph 1993). The value of DU comes from the traditional capacity and energy credit associated with a generating (or DSM) resource, as well as distributed benefits such as T\&D upgrade deferral, T\&D system loss reduction, service reliability enhancement, and risk reduction. These distributed benefits are made possible by installing modular generating systems on the distribution systems (or targeting DSM for specific areas) so that they are close to the loads; use of modules also enables utilities to install them in small increments to match specific demands. To provide the traditional and distributed benefits to utility systems, technologies for DU applications should have the following attributes:

(1) Technologies should be scalable to sizes that make them feasible for interconnections with utility distribution systems. The distribution systems of electric utilities are characterized by lower voltage and load carrying capability. The actual sizes of generators that can be interconnected at specific locations in the distribution system depend on factors such as the network configuration and existing load. In some places it may not be practical to connect a 10-MW generator to a distribution feeder. On the other hand, many distribution substations may be able to accommodate a 20-MW generator. There are no definite rules to dictate size. In order to maximize their applicability, we limited discussions to DU technologies that can be scaled up or down to the size of several megawatts. Most distribution feeders should be able to accommodate generators of this size.

(2) Power should be sufficient to alter local demand profiles through peak shaving. To solve T\&D system problems and capture the benefits of system additions and upgrade deferral, DU technologies must closely match output with local peak demands and have the capacity to alter these peaks. This criterion limits energy storage options for DU applications to battery systems. Additional energy storage options may become viable with further development. 
(3) The DU plants should be modular. In this report, modular technologies are loosely defined in terms of self-contained operational units. Unit modularity means that site preparation, field assembly, and installation requirements are greatly reduced, which shortens the lead time required to bring a plant on line. Shorter lead times reduce the financial risk associated with capital intensive projects for utilities. In addition, the costs of modular technologies are usually strongly influenced by the economies of mass production, but are insensitive to the economies of scale-an important factor when determining the costs of a conventional central station power plant. Typical examples of modular technologies include engine/generator sets, PV power plants, and wind energy systems. Per unit costs for modular technologies generally remain the same for a very wide range of sizes. There are no cost penalties for installing modular technologies in small increments to closely match a specific demand. Conventional steam units using fossil fuels or nuclear power do not have this attribute.

(4) The DU technologies have been successfully installed and operated in utility systems. Installing power generation systems at strategic points in utility distribution systems represents a significant departure from normal utility practice. Major concerns regarding power quality, safety and protection, and service reliability will arise. The technologies discussed in the report have all been tested to shown that they can operate individually in utility systems.

Many DSM technology options are available. However, the applicability and cost-effectiveness of DSM technologies are utility- and site-specific. Utilities must usually connect certain goals with DSM technologies and then evaluate end-use patterns of different classes of customers before selecting a particular technology. Because the performance of DSM technologies depends heavily on load characteristics and customer classes, the effectiveness of similar DSM technologies may be different within different utility systems. Similarly, costs for DSM technologies are not as straightforward as those for supply-side technologies. Regulatory processes heavily influence DSM cost allocations and utilities' decisions on DSM. Because providing a comprehensive DSM manual is not the purpose of this report, only a few DSM technologies for typical customer classes are included. 


\subsection{Supply-Side Distributed Utility Technology Options}

This section discusses cost and performance characteristics of the selected DU technologies. See Table 2-10 at the end of this section for a summary of the technical attributes and operating characteristics of these technologies. As discussed in Section 1.3, selection of supply-side DU technologies requires modularity and the ability to meet local peak demand. DU technologies derive significant value from their ability to defer costly distribution system upgrades. Modular technologies enable utilities to gain such benefits by closely matching the generating capacity with local demand without incurring cost penalties. By using modular technologies, utilities can plan adequately for and react quickly to changing local conditions and avoid overcapacity in generation and distribution systems.

Supply-side DU options include several mature and emerging generation technologies and battery energy storage systems. As discussed in Section 1.3, supply-side DU technologies are selected on the basis of their power and energy capacity, ability to be scaled down in size, modularity, and actual operating experience in utility systems. A battery energy storage system is not a generating technology, but can be a viable option in DU applications. The dish-Stirling system is an emerging solar thermal technology with high energy-conversion efficiency. If its technology development and commercialization progress as planned, it will become a valuable addition to the list of potential supply-side DU options.

Energy conversion efficiencies are given in describing the performance of selected supply-side DU technologies. It should be noted that efficiency measures by themselves are not very relevant for comparing different technologies, especially renewable energy technologies that have no fuel costs. For example, a PV panel with a 10 percent efficiency cannot be compared directly to an engine/generator set with a 33 percent efficiency. Efficiency, nevertheless, is a good indicator of a technology's state of the art. Conversion efficiency figures also enable planners and engineers to calculate energy costs with utility-specific financial parameters (for example, cost of money and resource data). Power densities for DU technologies, defined as capacity in $\mathrm{kW}$ per unit area in square meters, are also listed in the report. Power density relates to a technology's physical characteristics and is calculated from the estimated area required for the DU facility, not just the structural footprint of the actual equipment. This figure of merit will give an indication of the relative land requirements for different DU technologies. The cost figures in this report are installed costs and are converted to $\$ / \mathrm{kW}$.

\subsection{Engine/Generator Sets}

Engine/generator sets (also called generator sets) have long been used to provide standby power for critical loads and prime power for on- or off-grid applications. They combine a fossil-fueled engine and an electric generator to produce electric power. Standard three-phase induction or synchronous generators are used in the generator sets. Manufacturers provide control equipment for the generator sets to enable parallel operations with the utility grid, such as voltage regulation, block loading, and power factor control for synchronous generators, and stand-alone operations. The engine/generator sets are fully dispatchable by utilities to meet local and system load conditions. The engines can use diesel or natural gas as fuel.

Generator sets are a mature technology. They are very compact and modular. Packaged engine/generator sets are readily available in prefabricated modules. Major components are factory-built and skid-mounted, and only electrical and fuel connections are made in the field. Engine/generator sets with capacities in the range of $50 \mathrm{~kW}$ to $5 \mathrm{MW}$ are available for DU applications. Operational characteristics and performance of generator sets are well known to utilities. Generator sets have very short start-up times and offer utilities black start capability. The potential for efficiency and performance 
improvement, however, is not as high as that of emerging technologies because the major components of this technology are well developed. Consequently, costs of this technology are not expected to change significantly in the future.

For DU applications, the major concerns of engine/generator sets are fuel availability and local zoning and emission standards. The latter may limit the number of hours an engine/generator set can operate annually. Other issues are remote operation, dispatch of engine/generator sets, and unit maintenance.

\subsubsection{Performance}

A generator set usually employs a four stroke diesel engine to drive a synchronous generator. Diesel engines have a thermal efficiency of about 35 percent. Two fixed-speed operating modes are typical for diesel engines: low-speed (1200 rpm or less) and high-speed (1800 rpm or higher). Engine output increases with engine speed. Low-speed operations are quieter and offer better fuel economy. Highspeed operations provide higher output for the same engine package. Output per unit weight is higher and the cost per kilowatt is lower for high-speed generator sets. However, engine fuel economy will decrease at higher speeds because of increased friction losses. Depending on the size of the unit, the time required from cold start to full power ranges from a few seconds to almost 30 seconds.

With some minor modifications, diesel engines can use natural gas as fuel. Natural gas-fired engine/ generator sets offer cleaner operations than diesel-fired generator sets. Natural gas engines operate at lower pressures (about 40 percent to 50 percent lower than diesel engines), which results in longer engine life and reduced maintenance. For example, a natural gas-fired engine can operate 40,000 hours between overhauls, while a diesel-fired engine can run only 10,000 hours to 12,000 hours before an overhaul.

Heat rates for engine/generator sets operating at full load range from $7500 \mathrm{Btu} / \mathrm{kWh}$ to $9000 \mathrm{Btu} / \mathrm{kWh}$ for diesel operation (lower heat rate for low-speed operations). ${ }^{1}$ For natural gas operation, the heat rate at full load ranges from $9300 \mathrm{Btu} / \mathrm{kWh}$ to $10700 \mathrm{Btu} / \mathrm{kWh}$, based on the lower heating value of the fuel. When operating at half-load, thermal efficiency of both types will decrease by about 10 percent.

\subsubsection{Status of Technology}

Engine/generator sets using diesel fuel have been widely employed to provide prime and stand-by power. Many domestic and international suppliers are competing in the market. Pacific Gas and Electric Company (PG\&E) installed a 1-MW natural gas-fired engine/generator set in 1993 at their Ignacio substation to test the economic and technical viability of the technology in a DU setting.

\subsubsection{Cost}

The cost of diesel-powered generator sets rated up to $2 \mathrm{MW}$ is about $\$ 150 / \mathrm{kW}$. For natural-gas-powered generator sets, the cost is about $\$ 250 / \mathrm{kW}$. The necessary fuel handling, storage facilities, switch gear and controls that enable generator sets to operate in the utility grid will add $\$ 50$ to $\$ 100 / \mathrm{kW}$ to the cost. The operation and maintenance $(\mathrm{O} \& \mathrm{M})$ cost (excluding fuel cost) for a diesel-powered generator set is approximately $\$ 0.01 / \mathrm{kWh}$; half of this amount derives from the fixed $O \& M$ costs.

Table 2-1 summarizes the engine/generator set characteristics that are relevant to DU applications.

${ }^{1}$ Based on diesel fuel lower heating value of $42,700 \mathrm{MJ} / \mathrm{kg}(18,360 \mathrm{Btu} / \mathrm{lb})$. Data from manufacturer's specification sheets. 
Typical Heat Rate:

Diesel

Natural Gas

$\mathrm{NO}_{x}$ Emission (Diesel):

$\mathrm{NO}_{x}$ Emission (Natural Gas):

Utility Grid Interface:

Dispatchability:

DU Application:

Power Density:

Plant Costs:

O\&M Costs (excluding fuel):
7500-9000 Btu/kWh

9300-10700 Btu/kWh

$2.76 \mathrm{lb} / \mathrm{mmBtu}$

$3.1 \mathrm{lb} / \mathrm{mmBtu}$

Conventional

Yes

Peaking Duty

$50 \mathrm{~kW} / \mathrm{m}^{2}$

$\$ 200-\$ 350 / \mathrm{kW}$

$\$ 0.01 / \mathrm{kWh}$

\subsection{Gas Turbine/Generator Sets}

Gas turbine/generator sets use a gas turbine to drive a generator, usually a three-phase synchronous machine. Modern gas turbines can be designed to use a variety of fuels. Dual-fuel capability is common, and it allows switching from natural gas to distillate while the turbine is in full-load operation for additional operating flexibility. Other fuels, such as coal-bed methane or landfill gas, can be used to power the turbine.

Like engine/generator sets, gas turbine/generator sets are compact and modular. Packaged gas turbine/generator sets are readily available in prefabricated modules with major components being factorybuilt and skid-mounted. Only electrical and fuel connections are required in the field. Turbine/generator sets with capacities ranging from $500 \mathrm{~kW}$ to $25 \mathrm{MW}$ are suitable for DU applications.

For DU applications, the major concerns of turbine/generator sets are fuel availability, local zoning restrictions, and emission standards. The latter may limit the number of annual hours an engine/generator set is allowed to operate.

\subsubsection{Performance}

A gas turbine consists of an air compressor, a combustor, and an expansion turbine. Fuels are mixed with air and burned under compression to produce high-temperature gases. The hot gases pass through the expansion turbine, which drives the air compressor and generator. The power output of the gas turbine is sensitive to ambient and operating temperature. Full load thermal efficiencies range from 29 percent to 42 percent, but the efficiency falls off quickly when operating conditions deviate from the optimal load point. Figure 1 shows a typical gas turbine efficiency curve as a function of loading. For small units (rated up to $10 \mathrm{MW}$ ), the efficiency is in the 29 percent to 34 percent range at full load. By recovering heat from the turbine's exhaust, a total system efficiency of 70 percent to 90 percent can be achieved in a cogeneration mode. Typical full load heat rate for a small gas turbine/generator set (1 MW to $10 \mathrm{MW}$ ) is in the range of $11000 \mathrm{Btu} / \mathrm{kWh}$ to $14000 \mathrm{Btu} / \mathrm{kWh}$. 


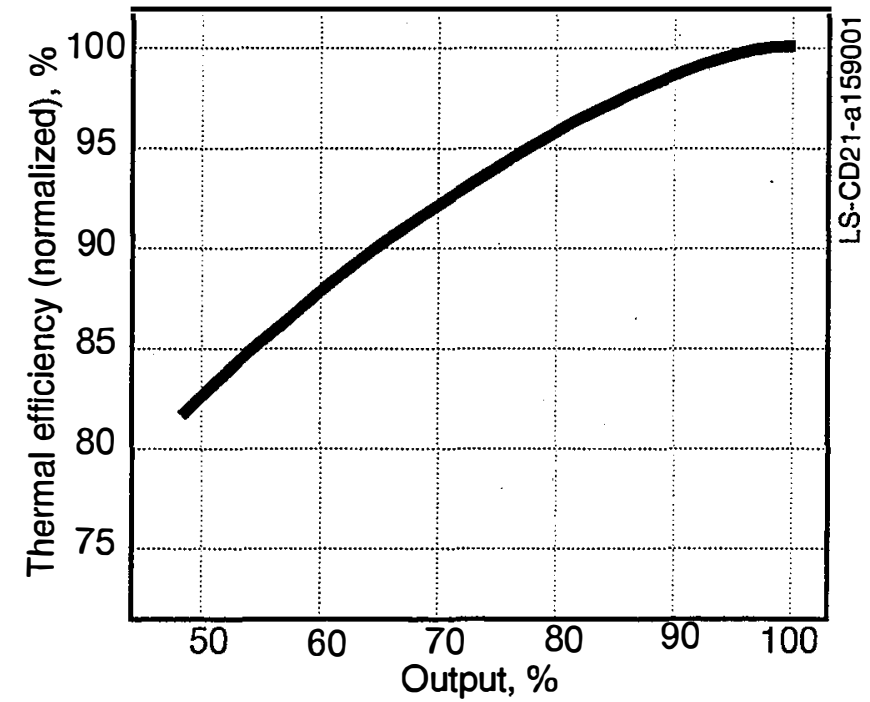

Source: Gas Turbine World, July - August 1993, p. 33

Figure 1. Gas turbine partial-load efficiency

Gas turbines have proven to be reliable generating sources. They have been used by many electric utilities to provide peaking and off-grid power. For small gas turbine generator sets (less than $10 \mathrm{MW}$ ), a cold start-up to full load takes about 40 seconds. With battery backup for the starting motors, gas turbine generator sets are capable of a black start. Gas turbine generator sets are fully dispatchable and can be used to follow the load, but they are usually operated at rated power for optimum efficiency.

Gas turbine generator sets are equipped with governor controls, which have the conventional droop frequency response characteristics. Standard control and protection devices are used. Operation of gas turbine generator sets is similar to other gas-fired power plants. They can be scheduled either as baseload units or as peaking units. A standard interface is used to interconnect the turbine/generator set with the utility grid. Utilities can dispatch the units to meet local and system load conditions.

Nitrogen oxides $\left(\mathrm{NO}_{x}\right)$ represent the only major emissions problem of gas turbines. $\mathrm{NO}_{\mathrm{x}}$ emissions are normally controlled by water or steam injection. Other dry-combustion technologies that operate without the need for fluid injection have also been developed to reduce $\mathrm{NO}_{x}$ emissions, but noise may restrict the operation of turbine/generator sets for some DU applications.

\subsubsection{Status of Technology}

Gas turbine/generator sets are mature technologies and they are available commercially from many suppliers. Increasingly strict $\mathrm{NO}_{\mathrm{x}}$ regulations have spurred the development of low $\mathrm{NO}_{\mathrm{x}}$ systems. Improved efficiency ratings for both large and small power plants are targeted in current research and development efforts. In the United States, the Collaborative Advanced Gas Turbine project, a combined effort of electric and gas utilities, gas turbine vendors, EPRI, and other research organizations and 
government agencies, leads the advancement of aeroderivative technology for utility power generation applications. In a separate project, the DOE's Advanced Turbine Systems program continues industrial/ government collaborative research and development to advance turbine technology. Incremental improvements in the technology are expected to continue.

\subsubsection{Cost}

The cost of small gas turbine generator sets $(1 \mathrm{MW}-10 \mathrm{MW})$ is in the $\$ 400 / \mathrm{kW}$ to $\$ 750 / \mathrm{kW}$ range (Gas Turbine World 1993). Smaller units are more expensive per kilowatt than larger units. Balance-of-plant costs fall in the $\$ 50 / \mathrm{kW}$ to $\$ 120 / \mathrm{kW}$ range.

Energy cost is a factor of the delivered fuel costs at a particular site. Routine maintenance cost of the gas turbine generator set will add about $\$ 0.005 / \mathrm{kWh}-\$ 0.0065 / \mathrm{kWh}$ to the energy cost (Weisert 1994; Lewis 1994).

Table 2-2 summarizes the turbine/generator set characteristics relevant to DU applications.

Table 2-2. Turbine/generator Set Characteristics

\begin{tabular}{lr}
\hline Typical Heat Rate: & $11,000-14,000 \mathrm{Btu} / \mathrm{kWh}$ \\
NO $_{\mathrm{x}}$ Emission (Natural Gas): & $0.61 \mathrm{lb} / \mathrm{mmBtu}$ \\
Utility Grid Interface: & Conventional \\
Dispatchability: & Yes \\
DU Application: & Peaking Duty \\
Power Density: & $59 \mathrm{~kW} / \mathrm{m}^{2}$ \\
Plant Costs: & $\$ 450-\$ 870 / \mathrm{kW}$ \\
O\&M Costs (excluding fuel): & $\$ 0.005-\$ 0.0065 / \mathrm{kWh}$
\end{tabular}

\subsection{Photovoltaics}

Photovoltaic technology converts sunlight directly into electric energy through the use of semiconductor devices. All PV systems use PV cells, which produce DC electricity from sunlight. Different semiconductor materials and techniques are used to fabricate PV cells. Some common types of cells include single-crystalline silicon, semi- or poly-crystalline silicon, thin-film crystalline, and amorphous silicon cells. Other materials that have shown great potential for producing low-cost PV cells are copper indium diselenide (CIS) and cadmium telluride (CdTe). PV cells are arranged into flat solar panels or used in conjunction with concentrator lenses of various sizes. The flat panels or concentrators comprise PV arrays. Tracking devices may be used to enhance the capture of sunlight energy. A static power conditioner is required to invert the $\mathrm{DC}$ electric power into $60 \mathrm{~Hz} \mathrm{AC}$ for utility grid connections. The design of PV systems is highly modular and can be easily sized to match the needs of specific applications. Except for the tracking systems, PV technology has no moving parts.

Compared to other modular generating technologies, such as fuel cells or generator sets, PV systems require relatively large areas to obtain significant amounts of power. The peak intensity of sunlight reaching the surface of the United States is about $1 \mathrm{~kW} / \mathrm{m}^{2}$. Due to limitations of DC conversion efficiency in PV cells and the arrangement of cells on a panel, a typical flat PV panel of about one square meter or less has a generating capacity of $50 \mathrm{~W}$ to $150 \mathrm{~W}$. However, the siting of PV systems can be 
very flexible. The PV panel is relatively light in weight and has no moving parts (unless a tracking system is used). It releases no emissions and does not require water during operation. PV panels can be mounted on the rooftop of buildings. This feature gives PV more siting flexibility and enables the installation of PV systems, even in densely populated areas. For DU applications, capacities of PV systems range from $1 \mathrm{~kW}$ to $1 \mathrm{MW}$.

\subsubsection{Performance}

PV systems are generally rated according to the power they can produce with specified solar radiation and ambient temperature. Efficiencies of PV cells range from 6 percent for amorphous silicon cells to as high as 32 percent for multi-junction concentrator cells (Green and Emery 1994). The efficiency of the static power converter is around 90 percent to 95 percent. Depending on the location and other design parameters (fixed-angle tilt or tracking), annual capacity factors of PV systems are in the 11 percent to 40 percent range.

Fixed-angle tilt PV systems face south and are slanted from the horizontal at an angle equal to the site's latitude. Tracking PV systems use motors and gear drives to point the PV arrays at the sun throughout the day. Single-axis tracking systems rotate the PV arrays about a fixed north-south axis only. Two-axis tracking systems rotate the PV arrays along both north-south and west-east axes so that they face the sun year-round. Depending on location, PV systems with two-axis tracking arrays receive 25 percent to 40 percent more global solar radiation annually than the fixed-angle tilt PV systems and therefore provide more power for longer periods.

The output of a PV system is a function of the amount of sunlight and cell temperature. Conversion efficiency decreases slightly as the cell temperature increases, as shown in Figure 2. Operating characteristics are determined mainly by the design of the static power converter that links the PV array to the utility power grid. Standard test procedure has been established by Photovoltaics for Utility Scale Applications (PVUSA) to test and predict the performance of PV systems (PVUSA 1992).

Electronic inverters are built with solid state electronic devices. These devices are configured to convert DC power to AC power. Earlier designs of line-commutated inverters used the $60-\mathrm{Hz}$ line voltage waveform to trigger switching. The resulting $\mathrm{AC}$ wave has a very high harmonic content. Because the inverter has to wait for the change in polarity of the $\mathrm{AC}$ line voltage to trigger the switching, its output always has a lagging power factor that requires external power correction. Removal of the voltage and current harmonics introduced by the switching action of the converter also requires significant filtering.

Newer inverter designs use the self-commutating technique for switching. The units contain an internal oscillator and have switching frequencies that are independent of the power line frequency. These inverters can closely approximate the sinusoidal waveform through high-frequency pulse modulation. The resulting AC output has much less harmonic content. The inverters easily meet industry standards for harmonics (IEEE 1992). Since they no longer depend on line frequency for switching, they can maintain unity or even leading power factors over their entire output range. This feature greatly enhances the operating flexibility of these later model inverters. 


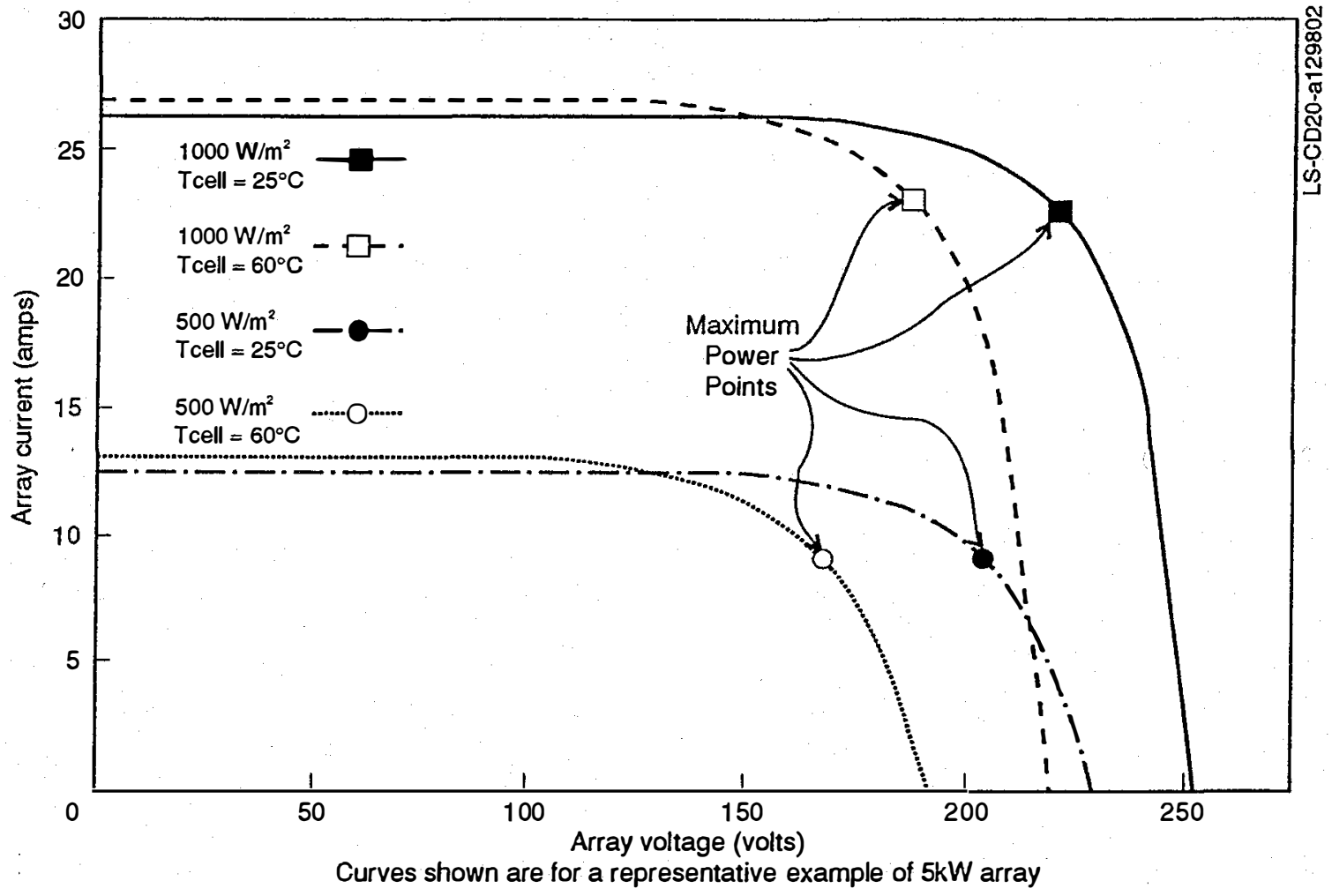

Figure 2. Typical current-voltage characteristic curve for a 5-kW PV array

Both PV arrays and static power converters are current-limiting devices. The PV arrays have a current/voltage characteristic, or I-V curve, as shown in Figure 2. The arrays are always designed to operate at the maximum power point, which is at the "knee". of the I-V curve. One important aspect of the PV arrays, revealed by the I-V curve, is their short-circuit current capability. Under short-circuit conditions, when voltage is near zero, the current is only about 15 percent higher than the current at the normal operating condition of the maximum power point on the I-V curve. Therefore, a PV power plant's ability to supply short-circuit current under fault is very limited (ANSI/IEEE Std 929-1988).

The current-limiting properties of static power converters and PV arrays also restrict PV systems' coldload pickup capability. If the load connected to the PV system is not properly sized for the capabilities of the arrays and static power converter, initial in-rush current occurring during the cold-load pickup could create problems.

Unlike conventional rotational generators, PV system output is independent of system frequency. PV plants can be described as inertialess in that they do not contain a large rotating mass. Their transient stability characteristics are different from those of conventional power plants. Under system disturbance, their power output and phase angles do not swing like conventional power plants using synchronous generators. Instead, PV plants can maintain constant power output. Industry standards have been established to guide the interconnection of PV systems and utility grids (ANSI/IEEE 1001-1988). 
PV output depends on the availability of sunlight. A good match between local load and PV output will increase the value of PV and is essential for DU applications. Another issue related to the DU applications of PV technology is the availability of land or rooftop space at the desired location.

\subsubsection{Status of Technology}

PV systems are commercially available and are currently used by many utilities for both stand-alone and grid-connected applications. In stand-alone applications, PV is used for small load applications where it is not economical to build distribution lines to serve the loads. Typical applications include waming sirens, beacons, communication links, cathodic protection on gas pipelines, and switches on transmission lines. There are several multi-megawatt-sized PV plants, including the former 6.6-MW Carrisa Plains PV plant, which is owned and operated by an independent power producer in the PG\&E service territory. The annual PV market reached 60 MW worldwide in 1993 (PV News January 1994).

PV systems installed by utilities have been operating in the field for nearly 15 years and have proven to be very reliable. The greatest improvement potential for PV technology lies in cell efficiency and in manufacturing techniques that reduce cost.

\subsubsection{Cost}

PV systems are highly modular, with plant and installation costs proportional to size. The major cost variations of PV systems derive from the different types of PV modules and mounting devices. The balance of a typical plant includes support structure, tracking devices, power conditioners, control devices, electrical wiring, site preparation and installations, and secondary systems, such as batteries. Except for tracking devices, the balance of PV plant costs are similar for any type of PV module. Lower-efficiency PV modules require a larger installation area, which drives their balance of plant costs higher compared to those of higher-efficiency modules. Several technologies are used to manufacture PV modules. Single crystal silicon currently is the leading seller, accounting for 21.5 peak MW or 37.1 percent of the 1992 worldwide market. Polycrystalline silicon is second, accounting for 20.2 peak MW or 34.9 percent. Installed costs for complete utility-scale PV were around $\$ 8,000 / \mathrm{kW}$ in 1993 , excluding land cost (PV News June 1994). Recent bids received by the Sacramento Municipal Utility District PV program have dropped to $\$ 6.68 / \mathrm{kW}$ for utility-scale $\mathrm{PV}$ plants and $\$ 6.25 / \mathrm{kW}$ for residential/commercial roof-top PV installations (PV News July 1994).

PV systems have relatively low O\&M costs per kilowatt-hour. Data from existing PV installations at Lugo (Hesperia, California), Carrisa Plains (San Luis Obispo County, California), and the Sacramento Municipal Utility District indicate that average large-scale plant O\&M costs range from 0.4 cent $/ \mathrm{kWh}$ to 1.1 cents/kWh (EPRI 1989). Projected future O\&M costs, based on the resolution of known problems at existing plants, the use of the best component designs, and the use of higher efficiency modules, range from $0.1 \mathrm{cent} / \mathrm{kWh}$ to $0.4 \mathrm{cent} / \mathrm{kWh}$ (EPRI 1989).

Various sources give slightly different PV cost predictions, but all are within comparable ranges. All sources point to a declining trend for PV modular costs. It also should be noted that PV modular costs are closely related to the quantities ordered (Hislop 1992; Real Goods 1991) and that cost differences could be significant between large and small quantities. Table 2-3, showing the costs and performance trends for different types of PV modules, is based on a 1993 industry publication (Maycock 1993). All figures are in 1990 dollars. Cost projections for copper indium diselenide and cadmium telluride modules were not provided. Others (Zweibel and Barnett 1993) estimated the costs of thin-film modules in the $\$ 750 / \mathrm{kW}$ to $\$ 2,100 / \mathrm{kW}$ range, assuming $10-\mathrm{MW}$ annual production capacity and 6 to 10 percent module efficiencies. 
Table 2-3. PV Module Costs and Performance Predictions

\begin{tabular}{llccc}
\hline & & $\mathbf{1 9 9 5}$ & $\mathbf{2 0 0 0}$ & $\mathbf{2 0 1 0}$ \\
\hline Module Cost & Single crystal silicon & 4,000 & 3,330 & 2,500 \\
$(\$ / \mathrm{kW})$ & Polycrystalline silicon & 3,330 & 2,500 & 2,200 \\
& Amorphous silicon & 3,330 & 2,000 & 1,500 \\
& Ribbon/sheet & 6,000 & 4,000 & 2,500 \\
& High-efficiency concentrator & 3,300 & 2,000 & 1,670 \\
\hline Module Efficiency & Single crystal silicon & 15 & 16 & $18-22$ \\
& Polycrystalline silicon & 16 & 17 & 22 \\
& Amorphous silicon & $7-9$ & 9 & 11 \\
& Copper indium diselenide thin-film & $8-10$ & 12 & 14 \\
& Cadmium telluride thin-film & $8-10$ & 12 & 14 \\
& Ribbon/sheet & 13 & 15 & 19 \\
& High-efficiency concentrator & 20 & 25 & 30 \\
\hline
\end{tabular}

The costs for the PV system balance of plant are predicted to follow a similarly decreasing path as production is scaled up and manufacturers advance further along the learning curve. Table 2-4 shows the projected trend of balance-of-plant costs for grid-connected PV systems with capacities ranging between $200 \mathrm{~kW}$ and $10 \mathrm{MW}$ (Maycock 1993).

Table 2-4. PV Balance-of-Plant Cost Forecast

\begin{tabular}{lccc}
\hline $\begin{array}{l}\text { Balance of Plant } \\
(\$ / \mathrm{kW})\end{array}$ & $\mathbf{1 9 9 5}$ & $\mathbf{2 0 0 0}$ & $\mathbf{2 0 1 0}$ \\
\hline Inverter & 300 & 200 & 150 \\
Wiring, controls & 80 & 60 & 50 \\
Labor, profit, misc. & 1,000 & 800 & 600 \\
Total & 1,380 & 1060 & 800 \\
\hline
\end{tabular}

\subsection{Wind Energy System}

Wind energy systems capture the kinetic energy contained in moving air masses and convert it to electrical power. Modern wind energy systems consist of wind turbines and supporting subsystems. A wind turbine is made of three basic components: (1) a rotor with two or three blades attached to (2) a drive train coupled with an electric generator, and (3) a tower and foundation supporting the rotor and drive train. The supporting subsystem includes electric collecting facilities such as controls, electrical cables, step-up transformers, etc. Blades of modern wind turbines are similar to the wings of an airplane. Fundamental aerodynamic principles of air movement and lift explain the operation of wind turbines. The energy flux, or power density, contained in moving air is equal to one half the density of the air $(\rho)$ times the cube of its velocity (v): 


$$
\mathrm{P}_{\mathrm{w}}=1 / 2 \rho v^{3} \mathrm{Watt} / \mathrm{m}^{2}
$$

Not all of the wind's kinetic energy can be extracted for useful work. The amount of power available for useful work depends on the efficiencies of the rotor, drive train, and generators. Existing wind turbines have a conversion efficiency of about 25 percent.

There are two basic types of wind turbine designs: horizontal axis (with the rotating axis of blades parallel to the wind and ground) and vertical axis (with the rotating axis of blades perpendicular to the wind and ground). Figure 3 shows the two basic wind turbine configurations. The majority of installed wind energy systems use the horizontal axis wind turbines (HAWT).

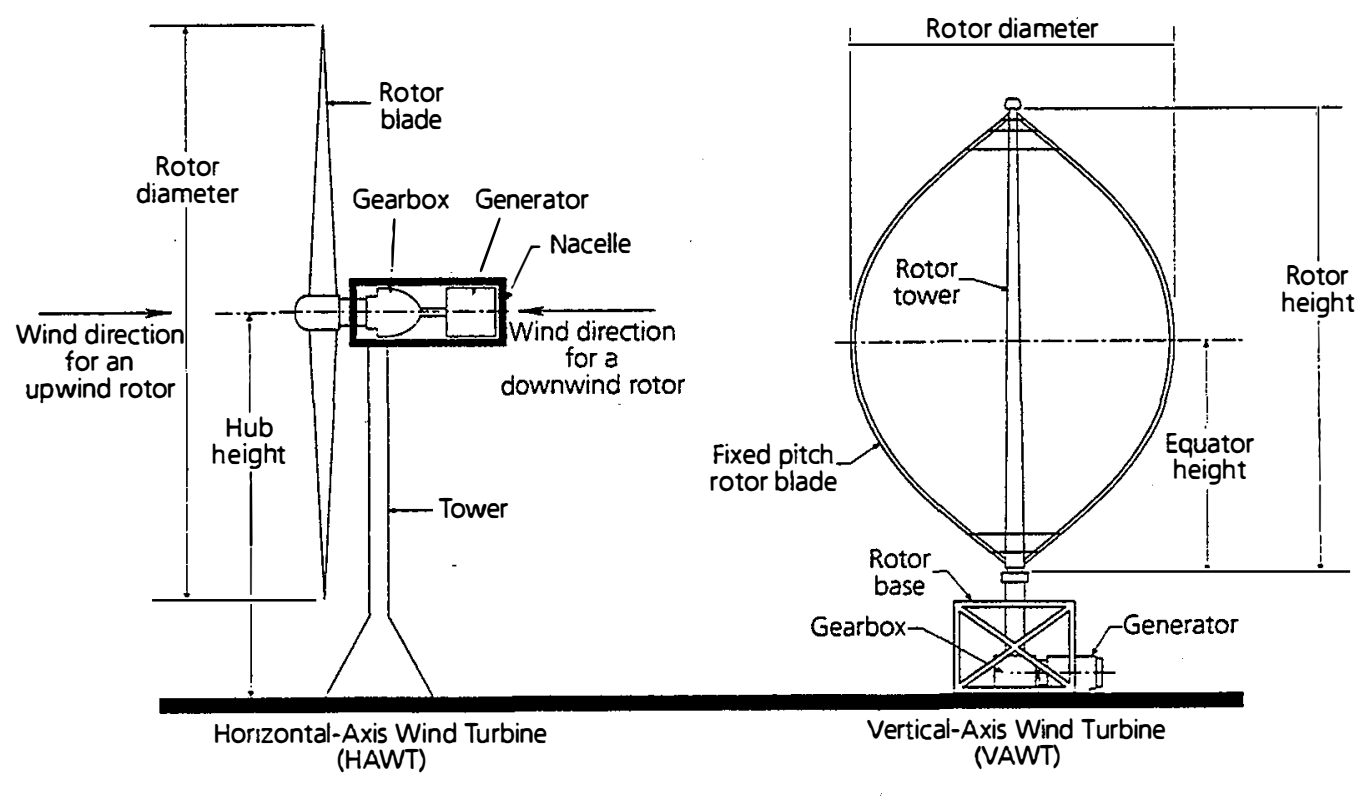

Figure 3. Two basic wind turbine configurations

There are other variations in HAWT configurations. For example, some HAWTs are designed to have the rotors facing the wind; others use rotors in the downwind position. Some HAWTs use blades attached to the hub at a fixed position to reduce design complexity (fixed-pitch turbines). Another design uses blades that rotate about their own axis and can change the angle at which they intercept the air stream to aid in regulating power output. These are called variable pitch turbines.

The vertical-axis wind turbine (VAWT) has its drive train and generator at ground level. This simplifies routine maintenance, but it cannot easily take advantage of greater wind speed and lower turbulence at higher elevations. HAWTs have self-support towers and need yaw control systems to orient the plane of the rotor to the wind. VAWTs do not need a yaw system to turn them into the wind and are usually supported by several guy wires fixed to the top of the towers.

Induction machines are the most commonly used electric generators for existing wind turbines. They are usually connected to the electric grid through step-up transformers and operated at a fixed speed. 
However, many new wind turbines are using electronic power converters with induction generators to enable variable-speed operation, which increases their energy capture.

\subsubsection{Performance}

Much wind turbine operating experience has been accumulated. Results from the operation of more than 17,800 wind turbines in Denmark and California during the past 10 years have shown that wind power plants are reliable energy sources for electric utilities (Cavallo, Hock, and Smith 1993). Recent trends indicate that the availability of wind turbines can reach 96 percent (CEC 1992). The capacity factor for newer turbines installed in California since 1985 is 23 percent (CEC 1993). This represents a remarkable improvement over the earlier average of 13 percent (Lynette, Young, and Conover 1989). The performance of windfarms at selected sites is even more impressive. For example, the 35 Vestas-Danish Wind Technology 400-kW wind turbines, installed near Palm Springs, California, achieved a 37.8 percent capacity factor during 1991 (Wind Energy Weekly 1992).

The electronic power converters of variable-speed wind turbines can improve power quality. As discussed previously in the PV section, the converters are capable of operating at both leading and lagging power factors. Even when wind turbines are not operating, the power converters can still be used to provide reactive power support to the electric grid.

Individual wind turbines are installed to form a grid in a wind power plant. The distance between rows of wind turbines can be 7 to 12 rotor diameters, and 2 to 10 rotor diameters between adjacent turbines to minimize interference caused by wake effects. Although a windfarm requires a relatively large land area, the actual land occupied by the wind turbines, access roads, and electrical systems is usually no more than 5 percent. The remaining 95 percent of the land area is almost completely undisturbed and can continue to be used for its original purpose.

Wind is an abundant renewable resource, and the operation of wind turbines results in no gaseous emissions and no solid and liquid wastes. Wind energy systems are a modular technology that does not require extensive site preparation during installation. Once all permits and contracts are in place, construction time can be less than six months.

For distributed utility applications, it is important to have a good match between wind energy output and local peak demand. Land availability is another factor that affects the applicability of wind energy systems.

\subsubsection{Status of Technology}

Wind technology has matured significantly since the first windfarm was developed in the United States in 1981. Wind energy systems are commercially available from many sources. More than $1655 \mathrm{MW}$ of utility-scale wind power systems were operating in California alone by the end of 1992, producing 2.7 billion $\mathrm{kWh}$ of electricity in 1992. The installed capacity of wind power plants continues to increase worldwide.

About 70 percent of all installed wind turbines in California are rated at $150 \mathrm{~kW}$ or less (CEC 1993). However, the trend in the United States is toward larger turbines in the $200 \mathrm{~kW}$ to $500 \mathrm{~kW}$ range. Sixtyeight percent of new wind capacity installed in California in 1992 was $200 \mathrm{~kW}$ or larger. While no megawatt-scale wind turbines are currently being developed in the United States, such research and development is active in Europe. 
Variable-speed wind turbines allow the generator to have a varying rotation speed and, hence, variable frequency from the utility grid frequency. By decoupling the rotor angular velocity from the utility grid frequency, annual energy output is increased and structural loads are reduced compared to a constantspeed turbine of the same size. Blade efficiency is at its highest when the ratio of the blade tip velocity to wind speed is about six for a HAWT. By allowing the blade rotation rate to vary to maintain this ratio over a wider range of wind speeds, annual energy output can be increased by more that 10 percent (Cavallo, et al. 1993). Kenetech Windpower supplies one of the commercially available variable-speed wind turbines (model 33M-V5). It has three blades with a rotor diameter of 33 meters and is rated up to $400 \mathrm{~kW}$. $^{2}$

Current wind technology research and development efforts for utility-scale applications are following several concurrent, yet distinct, paths. The first is development of lightweight designs under the DOE Advanced Wind Turbine (AWT) program and through the efforts of wind turbine manufacturers. The second, also being supported by AWT, is to improve existing designs through value engineering. Several windfarm operators and manufacturers believe substantial improvements in cost/performance characteristics can be realized along this path. The third is the variable speed design mentioned above. This design is being pursued by Kenetech Windpower and several utility partners. It is likely that several designs resulting from these efforts will survive in the future market, and they will converge in terms of overall cost and performance (EE Technology Characterization 1994).

\subsubsection{Cost}

The current capital cost of utility-scale wind turbines is about $\$ 860 / \mathrm{kW}$ for Kenetech Windpower 33M-VS variable-speed wind turbine (Brower et al. 1993). With transmission interconnection, substation, land, and other indirect/permitting costs, the total installed cost for a 50-MW windfarm is estimated at $\$ 942 / \mathrm{kW}$ (Brower et al. 1993). For small wind turbines, the capital costs are higher. For example, the price for an Atlantic Orient Wind Systems AOC 15/50 wind turbine (15-m rotor diameter, 50-kW with a wind speed of $12.8 \mathrm{~m} / \mathrm{sec}$ at $25 \mathrm{~m}$ hub height) is $\$ 61,000$, or $\$ 1,220 / \mathrm{kW}$ (Atlantic Orient Corporation 1993).

Routine maintenance for wind turbines includes periodic inspection, lubrication, cleaning, and replacement of expendable components like brake pads, oil filters, etc. Expenses for O\&M include the cost of monitoring power output and other parameters of the working turbines, general project maintenance, environmental impact mitigation, and major overhauls over the designed 30-year life of the system. O\&M costs for well-designed and well-built wind turbines in California are about $\$ 0.0093 / \mathrm{kWh}$ to $\$ 0.013 / \mathrm{kWh}$ (CEC 1992). Experience with windfarm operations in Denmark shows a similar O\&M cost range (Vesterdaak, 1992). The O\&M costs are expected to fall with advanced turbine designs.

Table 2-5 gives the cost and performance data of current and future wind turbines (Cohen 1993). All costs are reported in 1993 dollars. Land costs vary and are influenced by regional land availability. Current practice is a royalty payment to the land owner, based on the project revenue.

${ }^{2}$ The rating depends on the average wind speed at the site. 
Table 2-5. Projections for Cost and Performance of Wind Turbines

\begin{tabular}{lrrrrrr}
\hline & 1995 & 2000 & 2005 & 2010 & 2020 & 2030 \\
\hline $\begin{array}{l}\text { Turbine rating } \\
(\mathrm{kW})\end{array}$ & 300 & 500 & 750 & 1000 & 1000 & 1000 \\
$\begin{array}{l}\text { Hub height } \\
(\mathrm{m})\end{array}$ & 37 & 60 & 70 & 80 & 90 & 100 \\
$\begin{array}{l}\text { Rotor diameter } \\
(\mathrm{m})\end{array}$ & 28 & 38 & 46 & 53 & 53 & 53 \\
$\begin{array}{l}\text { Capacity factor* } \\
(\%)\end{array}$ & 23.9 & 30.2 & 31.4 & 33.1 & 34.7 & 36.3 \\
$\begin{array}{l}\text { Availability } \\
(\%)\end{array}$ & 98 & 98 & 98 & 98 & 98 & 98 \\
$\begin{array}{l}\text { System cost } \\
(\$ / \mathrm{kW})\end{array}$ & 775 & 750 & 742 & 726 & 710 & 700 \\
$\begin{array}{l}\text { System O\&M cost } \\
(\$ / \mathrm{kWh})\end{array}$ & 0.01 & 0.008 & 0.007 & 0.006 & 0.005 & 0.005 \\
$\begin{array}{l}\text { Fixed O\&M cost } \\
(\$ / \mathrm{kW} / \mathrm{yr})\end{array}$ & 4.2 & 4.0 & 4.0 & 3.1 & 2.2 & 2.2 \\
\hline
\end{tabular}

* For $5.8 \mathrm{~m} / \mathrm{sec}$ (annual average) wind sites

\subsection{Battery Storage System}

Batteries are the most familiar energy storage devices. Large-scale energy storage technology using batteries is commercially available. Utilities have used batteries in many energy storage applications. Lead-acid batteries are the most widely used type of battery in utility-scale applications. The ability to store and deliver electricity as needed provides utilities with greater operating flexibility and the opportunity to reduce power production cost. Quick response is one of the technology's advantages because battery storage systems can respond to changing loads within the millisecond range. A 500-kW, 1-hour battery system has been operated successfully since 1983 at Crescent Electric Membership Cooperative in Statesville, North Carolina. A much larger battery system (10-MW with 4-hour capacity) has been in commercial operation since 1991 at Southern California Edison Company's Chino Substation. Puerto Rico Power Authority installed a 20-MW, 14-MWh battery energy storage system in 1993. Several other battery energy systems in the United States and overseas are described by Cook, Spindler, and Grefe (1991).

A battery energy system includes the battery cells and a power conversion system (static power converter/inverter). The balance of the plant consists of the building, instrumentation, ventilation and air conditioning, and chemical storage and handling equipment. Battery energy storage plants are modular and can be configured in sizes ranging from a few hundred kilowatts to $20 \mathrm{MW}$. Their storage capacities range from 1 to 4 hours.

The power conversion system provides an interface between DC batteries and AC utility systems. This subsystem charges and discharges the batteries according to control signals that set power levels, directions, and durations. The power conversion system uses solid state electronics similar to the equipment found in large uninterruptible power supply systems. Standard power transformers and AC 
switching devices are included with the power conversion system. A functional battery energy plant also includes the necessary civil, structural, mechanical, and electrical support systems. Most of the balance of plant equipment is commercially available in the standard industry design. However, integration of the battery, power conversion system, and auxiliary equipment requires a thorough understanding of unique system characteristics and interface requirements.

Two types of lead-acid batteries are available: the flooded cell design and the newer valve-regulated (VR) design. The VR batteries are designed to be maintenance free. ${ }^{3}$ In these batteries, the electrolyte is immobilized as a gel or absorbed in a glass mat. Its rate of water loss is so low that the initial amount of electrolyte is sufficient for the service life of the battery, and no water replacement is necessary. Conventional flooded cell batteries require periodic addition of water to the cells. They also can be made maintenance free with special construction features to reduce water loss in the electrolytes. Compared to maintenance-free batteries, conventional design flooded batteries usually require a larger building for the same plant energy rating because the batteries must be installed upright with sufficient space above each one for addition of water. Maintenance-free flooded batteries and VR batteries can be packed much more compactly because provisions for adding water are not required. Presently, VR batteries are more expensive and do not have the proven history in deep discharge and high cycle life that flooded batteries do.

When fully charged, battery energy storage systems are considered dispatchable for utility applications. Key advantages of a battery storage system include quick response to load changes, black start capability, zero emissions, ${ }^{4}$ quiet operation, modular design, and siting flexibility that enables the system to be installed near load centers and in existing urban substations.

\subsubsection{Performance}

Batteries store electric energy through reversible electrochemical processes. Electric energy is converted to chemical energy for storage, and subsequently the chemical energy is reconverted to electric energy. The electrochemical reactions take place in battery cells, which typically consist of electrode plates separated by an electrolyte. During discharge, electrons flow from one electrode (the anode) to another (the cathode) through an external electric circuit connected to the electric load. To recharge the system, an external source of electric power is applied to the electrodes to reverse the direction of the electron flow. The electrolyte is typically in liquid form, such as acid or alkali solution, which provides ionic conductivity.

Battery cells produce DC current. They are connected in parallel and in series to obtain desired current and voltage capacities. A static power converter/inverter is used to convert DC electricity to AC for interconnection with the utility grid and to invert utility $\mathrm{AC}$ power to DC electricity for battery charging.

Battery energy plants are considered dispatchable after they are charged and can respond to rapid load fluctuations. A fully charged battery energy plant has an extremely fast response time, reaching its full output in four cycles, or about $67 \mathrm{msec}$. Batteries generally require two hours of charging for every hour

3 "Maintenance free" means that periodic replacement of water in the battery cells is not required (Berndt 1993).

${ }^{4}$ Battery energy storage plants themselves do not produce air pollutants, but, depending on the source of charging energy, operations of battery plants may result in more emissions due to energy losses of the charge-discharge cycles. 
of discharge. Typical AC-to-AC efficiencies for a battery energy system are in the 72 percent to 75 percent range (Eckroad and Radimer 1991).

A battery energy plant can be operated over its full range of output without adversely affecting its operating efficiency. However, a battery's available energy in kilowatt-hours or megawatt-hours varies with its power output in kilowatts or megawatts. Figure 4 shows a representative curve of battery capacity ${ }^{5}$ versus discharge rate. The discharge rate is expressed at the bottom as "c." It is defined as the capacity in ampere-hours (Ah) divided by the number of hours of constant operation. Battery energy plants can be used to provide maximum power over a fixed period in a block discharge mode, or they can be used to follow the load in a variable discharge mode. Since the available energy of batteries increases with decreasing power output, battery energy plants can supply power to the load longer in the variable discharge mode. System requirements determine the mode of battery energy plant operation and should be carefully considered before a particular plant design is selected for evaluation.

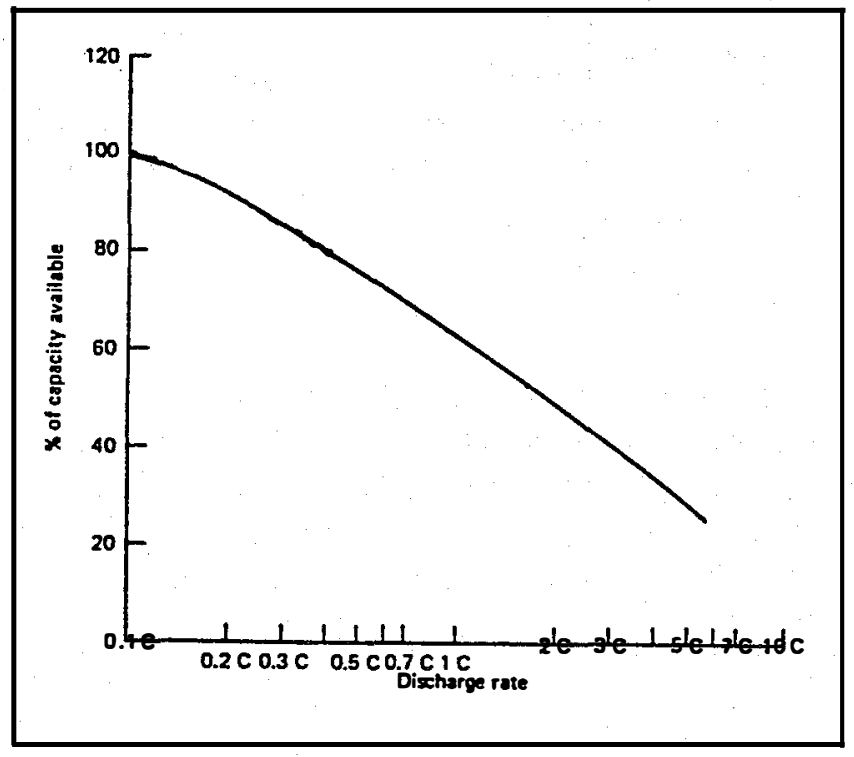

Figure 4. Battery capacity versus discharge rate

In normal operation, battery energy storage plants have no noticeable effects on the environment. Depending on the charging rate, lead-acid batteries will release a small amount of hydrogen gas. This gas has to be vented properly to eliminate explosion hazards. Flooded lead-acid batteries also require periodic watering to make up the electrolyte lost during charging. There are no moving parts in battery energy storage technology and battery operation is very quiet. Special considerations for battery system operations include prevention and protection against accidental chemical spills and disposal of chemical wastes. These precautions are required for all battery energy storage plants.

${ }^{5}$ Battery capacity is defined as the constant current it takes to discharge the battery to its cutoff voltage multiplied by the hours it takes to reach the cutoff voltage at this current. It has the dimension of ampere-hour (Ah). 
Battery life is a function of discharge cycles and the depth of discharge. Some flooded cell lead-acid batteries are capable of more than 2000 cycles at 80 percent depth of discharge. For applications that require frequent shallow depth-of-discharge cycles, such as frequency regulation, battery life is not expected to be affected. A 17-MW, 14-MWh battery system that has been used in Berlin since 1986 by the local utility for frequency regulation and spinning reserve duties has not shown any signs of capacity or life degradation (Akhil et al. 1993). Maintenance free batteries presently have a shorter life than conventional flooded cells for the same depth of discharge. New design may reduce this difference.

\subsubsection{Status of Technology}

Battery storage using lead-acid batteries is a well-established technology, and utility-scale lead-acid battery energy storage plants are commercially available. Advanced batteries based on other electrochemical combinations exist in various stages of development. The performance characteristics of lead-acid battery storage systems are well known. The improvement potential for utility applications lies in the integration of power conversion systems with batteries and the development of advanced batteries. Interest in electric vehicle applications will speed the development of advanced battery systems. Several advanced battery technologies are being developed for both electric utility and electric vehicle use. These advanced batteries are expected to store more energy in a smaller package, last longer, and cost less than lead-acid batteries. Among the advanced batteries under development, sodium/sulfur (a high-temperature battery) and zinc/bromine (a flowing electrolyte battery) show potential to meet the cost and life requirements for utility storage applications (DOE 1994). The new batteries may not be available for utility applications, however, for another decade. In this report, only lead-acid batteries are discussed.

Self-commutated inverters are replacing line-commutated inverters in power conversion systems. The self-commutated design is less prone to commutation failures, and due to its unidirectional voltage characteristic is a better match to the battery, which is a unipolar voltage device. Self-commutated inverters can have very rapid turn-on and power flow directional change (20 to $100 \mathrm{msec})$. They can be operated at a wide range of lagging and leading power factors that are independent of real power output. This capability enables the system to continue providing power in the event of $\mathrm{AC}$ line failure. It also enables such systems to offer reactive power support to the network.

In 1991, Sandia National Laboratories funded development of the AC battery with Omnion Power Engineering Corporation. The AC battery system is a modular system designed for outdoor service. It requires minimum site preparation and little maintenance for normal operations. The prototype is a $250 \mathrm{~kW} / 167 \mathrm{kWh}$ battery system in a truckable container with external dimensions of $4.57-\mathrm{m} \times 2.29-\mathrm{m}$ x 3.35-m (15 ft long x $7.5 \mathrm{ft}$ wide $\times 11 \mathrm{ft}$ high). Eight modules of 48, 12-volt, maintenance-free lead-acid batteries and a power conditioning unit are housed in the container. This self-contained system can be easily relocated within a utility's service territory. An AC battery was installed by PG\&E in 1993 and is currently undergoing field testing.

\subsubsection{Cost}

Battery energy plant capital costs are strongly connected to the energy rating of the battery system. The type and number of planned charge-discharge cycles will determine the battery requirements and affect their costs. Total battery cost consists of two components:

$$
\mathrm{C}_{\text {toosl }}=\mathrm{C}_{\mathrm{p}}+\mathrm{C}_{\mathrm{s}} \times \mathrm{t}
$$

where $C_{p}=$ cost of power component $(\$ / k W)$

$\mathrm{C}_{\mathrm{s}}=$ cost of stored energy component $(\$ / \mathrm{kWh})$ 


$$
\mathrm{t}=\text { storage time }(\mathrm{h}) \text {. }
$$

For lead-acid batteries, the $C_{p}$ component is in the $\$ 260 / \mathrm{kW}$ to $\$ 325 / \mathrm{kW}$ range, and the $\mathrm{C}_{\mathrm{s}}$ component is in the $\$ 76 / \mathrm{kWh}$ to $\$ 127 / \mathrm{kWh}$ range. Higher cost figures represent costs of heavy-duty batteries that are designed to be frequently and deeply discharged (i.e., 200 to 250 of 60 percent to 80 percent depth of discharge cycles per year). Lower cost figures represent costs of light-duty batteries that are designed for infrequent discharges ( 50 cycles per year), deeply or otherwise. In addition to these components, total installed costs of a battery energy system include $\$ 375,000$ to $\$ 300,000$ in fixed costs. ${ }^{6}$ For a $1-\mathrm{MW}$, 1 to 3 hour lead-acid battery storage plant, capital costs fall in the $\$ 830 / \mathrm{kW}$ to $\$ 1,080 / \mathrm{kW}$ range. Puerto Rico Power Authority installed a 20-MW, 14-MWh battery energy storage system in 1993 at a project cost of $\$ 16.9$ million (Akhil et al. 1993).

Capital costs for the $250-\mathrm{kW}, 167-\mathrm{kWh}$ AC battery are about $\$ 1,000 / \mathrm{kW}$. Estimated site preparation cost is $\$ 5,000$ per installation. Capital costs are expected to drop to $\$ 750 / \mathrm{kW}$ with an annual market of 20 MW. The fixed O\&M cost is estimated at $\$ 19,000$ per year.

For a hypothetical $20-\mathrm{MW}, 1$-hour battery plant, estimated fixed O\&M cost per year is $\$ 1.6 / \mathrm{kW}$ (EPRI TAG 1993). Incremental O\&M cost is $\$ 0.0076 / \mathrm{kWh}$. The cost of charging energy is not included in the O\&M cost figures. The expected service life of batteries is not as long as that of the balance of the battery energy plant, and battery replacement costs are highly uncertain because they are a function of shelf life, duty cycle, depth of discharge, and other operating factors. These costs are not included in the initial capital cost of the battery energy plant.

Table 2-6 summarizes the characteristics of battery energy storage systems:

Table 2-6. Battery Plant Characteristics

\begin{tabular}{lr}
\hline Emission: & N/A \\
Utility Grid Interface: & Electronic Power Inverter \\
Dispatchability: & Yes \\
DU Application: & Peaking Duty \\
Power Density (conventional plant): & $1.6 \mathrm{~kW} / \mathrm{m}^{2}$ \\
$\quad$ (AC battery system): & $23.9 \mathrm{~kW} / \mathrm{m}^{2}$ \\
Plant Costs: & $\$ 830$ to $\$ 1,080 / \mathrm{kW}$ \\
O\&M Costs: & $\$ 0.0076 / \mathrm{kWh}$ \\
Energy Requirement, & \\
3-hour battery (kWh output/kWh input) & \\
Full load & 0.73 \\
25\% load & 0.78 \\
Average (annual) & 0.74 \\
\hline
\end{tabular}

\footnotetext{
${ }^{6}$ Notes from EPRI Workshop on Battery Storage Applications, 22-23 September 1992, Burlingame, CA.
} 


\subsection{Fuel Cells}

Fuel cells are highly efficient power generating systems that produce DC electricity by combining fuel and oxygen in an electrochemical reaction. Fuel cells can be designed to use a variety of fuels, such as natural gas, landfill gas LPG, propane, coal gasification, and hydrogen. Compared with traditional generating technologies that use combustion processes first to convert fuel to heat and mechanical energy, fuel cells convert the chemical energy of a fuel to electrical energy directly; without intermediate conversion processes. Fuel cells, therefore, are not limited by the Carnot efficiency of thermal engines. Fuel cells not only offer the most efficient means of generating electricity from fossil fuels, but also have very low emissions. Up to 80 percent of the energy obtained from the fuel supply in fuel cells can be converted to usable electric power and heat. Furthermore, a fuel cell's efficiency is largely independent of its size and output level. Fuel cells can operate at half their rated capacity while maintaining high fueluse efficiencies. Almost all fuel cell power plants are operated in the cogeneration mode because of the clean and high grade waste heat they produce.

Phosphoric acid fuel cells (PAFC) are the most mature fuel cell technology and are commercially available now. Sizes range from $200 \mathrm{~kW}$ to $11 \mathrm{MW}$. This type of fuel cell has been operating successfully in Japan for several years. Current phosphoric acid fuel cell design has an electrical conversion efficiency of 41 percent. Major improvements await in the areas of capital cost reduction, stack life extension, and O\&M cost reduction. The fuel cells that are likely to be widely used by utilities will be the more advanced molten carbonate and solid oxide designs. Molten carbonate fuel cells (MCFC) and solid oxide fuel cells (SOFC) offer higher efficiency, greater compactness, and potentially lower cost than phosphoric acid fuel cells.

Existing commercial fuel cell plants, as well as systems still in the developmental stage, have been designed so the major components of various subsystems can be preassembled in modular form at the factory. The inherent scalability of fuel cell stacks and the interchangeability of major components contribute to the modular nature of a fuel cell plant. This modularity simplifies site preparation and layout, shortens project lead time, and offers electric utilities the ability to add capacity in small increments without sacrificing economies of scale. In addition to its relatively constant efficiency over a wide range of loads, a fuel cell plant also has a very fast response time to load changes. This feature provides more operating flexibility to utilities.

Commercial fuel cell power plants should have higher reliability than combustion turbine or reciprocal engine-based power generating technologies because they contain fewer moving parts. Except for periodic stack reload; fuel cells require less routine maintenance during normal operations than other fossil fuel-based power plants. Phosphoric acid fuel cell units in commercial operation have run continuously for more than 5,500 hours (The Energy Daily 1993), which is comparable to many fossil fuel-based power plants.

Fuel cell power plants consist of three major subsystems: a fuel processing subsystem (the reformer), the fuel cell stack subsystem, and the power conditioning unit (static power converter). The reformer converts the fuel supply to a hydrogen-rich fuel gas. It can be designed to accept many different fuels, including hydrogen, natural gas, propane, methanol, and coal gas. The fuel cell stack subsystem is where the electrochemical process occurs and the DC electricity is produced. The static power converter subsystem converts DC power to AC power.

Conventional fossil-fueled power plants are designed to operate most efficiently at a certain load level (usually full load) and show a rapid decline in efficiency at part load. However, the overall efficiency 
of a fuel cell plant tends to be approximately independent of load. For example, Figure 5 shows the typical efficiency vs. power curve for MCFC (Energy Research Corp. 1992).

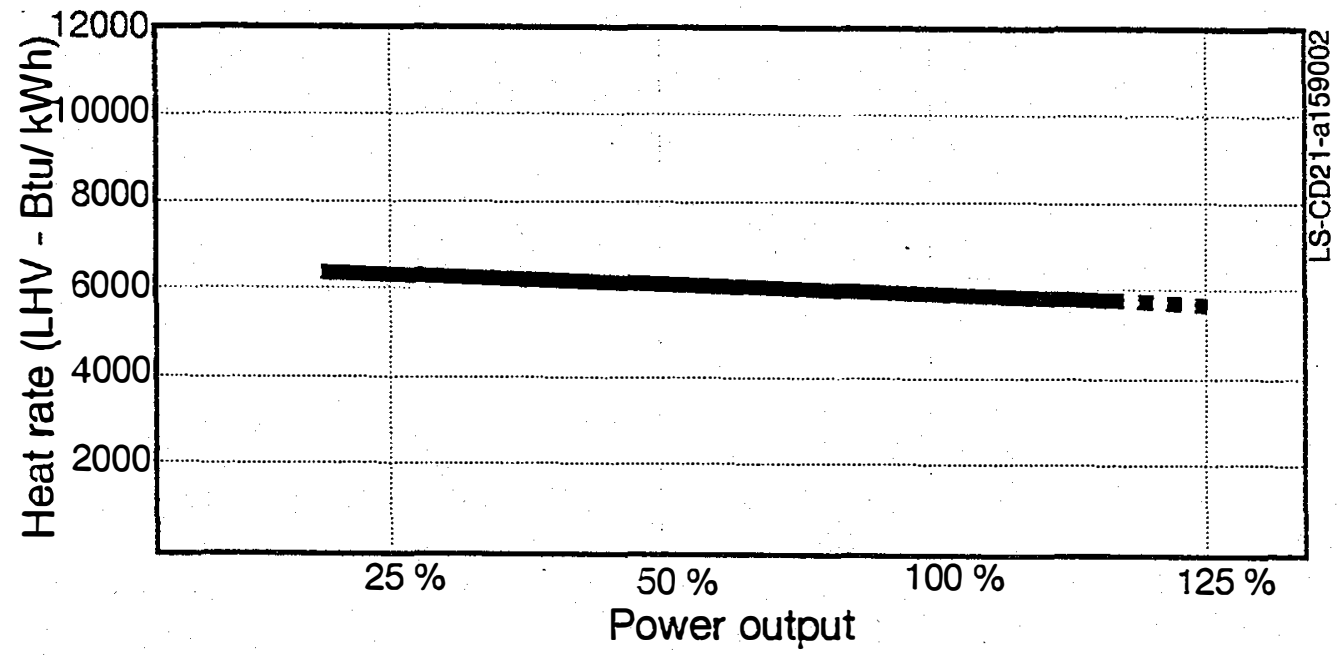

Source: Fuel Cell Engineering Corporation

Figure 5. 2-MW MCFC power plant efficiency curve

Many of the sources of noise associated with conventional steam or combustion turbine power plants are eliminated in fuel cell power plants because the electrochemical process in fuel cells is quiet. This easily puts the fuel cell power plant into compliance with existing Occupational Health and Safety Administration (OSHA) standards. Due to their higher conversion efficiencies, fuel cells also produce fewer carbon dioxide $\left(\mathrm{CO}_{2}\right)$ emissions than conventional power plants of comparable size. Substitution of fuel cell plants for conventional fossil fueled plants should improve air quality and reduce water consumption.

Static power converters isolate fuel cells from the disturbances of the utility power grid. Like PV systems with static power converters, fuel cell power plants do not contribute short-circuit current to the utility grid.

\subsubsection{Performance}

Fuel cells combine hydrogen and oxygen to generate electricity. The by-product of this process is water. The source of hydrogen in existing commercial fuel cell plants is natural gas or coal gas. Air supplies the oxygen.

The desired voltage of the fuel cell plant is obtained by connecting individual cells in series to form a cell stack. Fuel cell stacks are configured into blocks for desired power levels. DC output is converted by a static power converter into $\mathrm{AC}$ to be interconnected with the electric grid. Stack performance decays slowly over time. Current estimates of fuel cell stack life range from 5 to 7 years. The frequency of 
stack replacement depends on the design tradeoffs between plant heat rates, fuel prices, and stack replacement costs (EPRI 1992).

The electrochemical processes of fuel cells make this technology suitable for continuous operation with steady output. Load following is possible with additional control and communication equipment at the plant. Fuel cell power plants are being designed to operate automatically with remote control dispatching the units.

Phosphoric Acid Fuel Cells Phosphoric acid fuel cells use liquid phosphoric acid as an electrolyte. Figure 6 shows a simplified schematic diagram of a phosphoric acid fuel cell. At the anode, hydrogen gas is ionized to produce hydrogen ions and electrons. The electrons travel from anode to cathode through an external circuit. Hydrogen ions travel to the cathode through the electrolyte. At the cathode, oxygen reacts with the hydrogen ions and the electrons to form water.

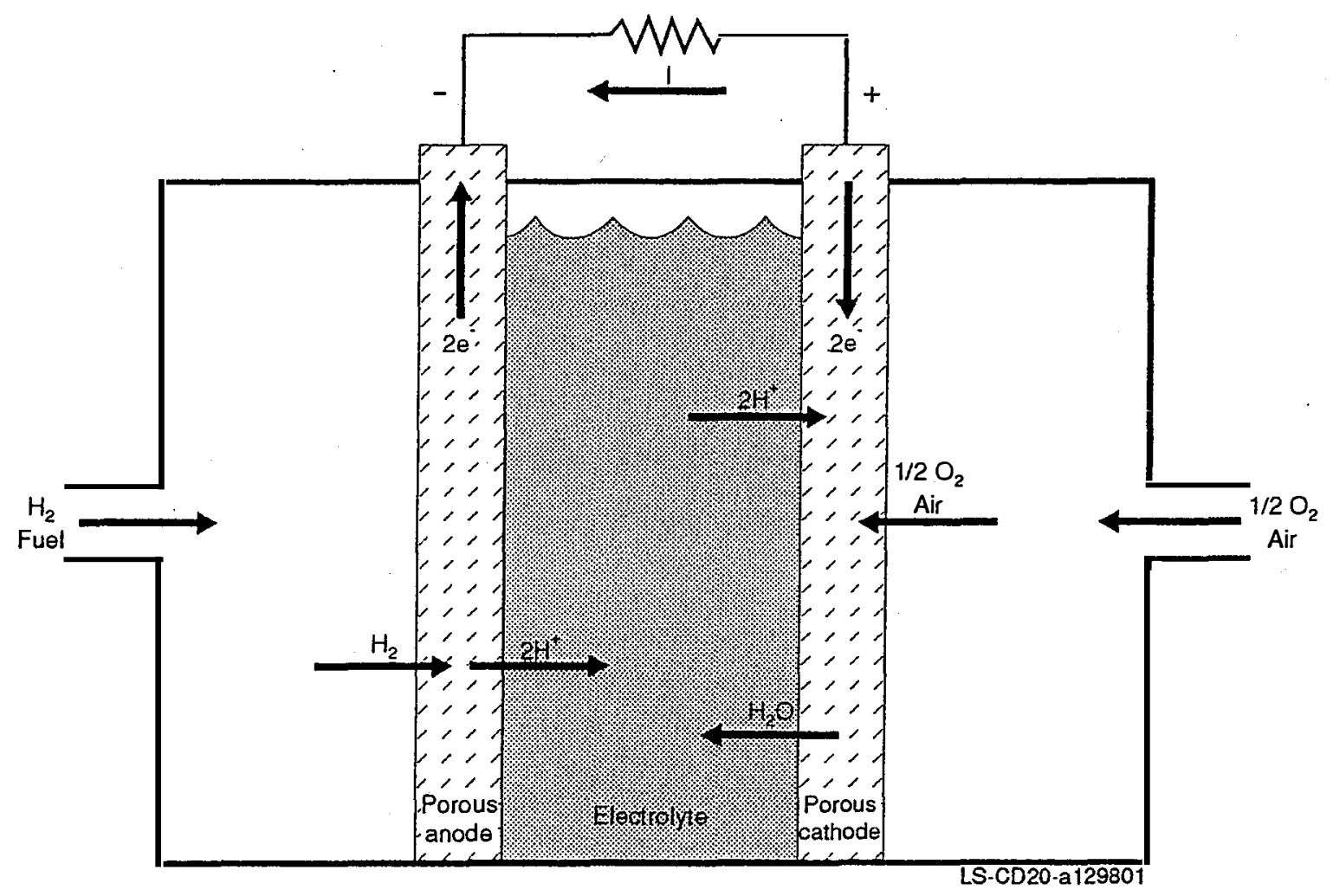

Figure 6. Phosphoric acid fuel cell schematic diagram

The overall reaction in the fuel cell is the combination of hydrogen with oxygen to produce water. This reaction is different from the conventional combustion of hydrogen and oxygen. Instead of the entire free energy being released as heat, part of the energy is released directly as electricity. The balance of the energy is released in the form of heat as the temperature rises in the fuel cell. The product water may 
enter the electrolyte or be lost through the cathode as vapor. Careful water management of the electrolyte may be necessary, depending on operating temperature and other conditions. The operating temperature of phosphoric fuel cells is about $200^{\circ} \mathrm{C}$. Emissions of PAFC plants are very low - on the order of 1 $\mathrm{lb} / \mathrm{MW} /$ day for the sum of nitrogen oxides $\left(\mathrm{NO}_{\boldsymbol{\gamma}}\right)$ and sulfur oxides $\left(\mathrm{SO}_{\boldsymbol{x}}\right)$ at a $200-\mathrm{kW}$ plant. Current plant electric efficiency is about 41 percent with a heat rate of $8535 \mathrm{Btu} / \mathrm{kWh}$.

Hydrogen needed for the fuel cells is converted from natural gas by a well known industrial process: catalytic steam reforming conversion. Steam for the reforming process is generated by heat from the fuel cells. Water is condensed out of the fuel and steam mixture and recycled through the system. Below certain operating temperatures and power output levels, full water recovery can be accomplished. A cold start of the ONSI 200-kW PAFC unit takes 5 hours.

The ONSI 200-kW PAFC plant is contained in three preassembled modules. The complete operational system requires an area of less than $84 \mathrm{~m}^{2}\left(900 \mathrm{ft}^{2}\right)$. The power conditioning unit, process air blower, and ventilating and cooling fans are the primary sources of noise in the fuel cell power plant. The maximum sound level is estimated to be $60 \mathrm{dBA}$ at 30 feet from the unit. This sound level is less than the background noise level at most commercial building sites.

Molten Carbonate Fuel Cells Molten carbonate fuel cells are a type of direct fuel cell that eliminate external fuel processors. Methane (the main ingredient of natural gas) and steam are converted into a hydrogen-rich gas in the reforming anode or in a reforming chamber, which are part of the fuel cell stack. The fuel cell stack comprises two porous electrodes in contact with a molten salt of lithiumpotassium carbonate $\left(\mathrm{LiKCO}_{3}\right)$. It operates at approximately $650^{\circ} \mathrm{C}$.

At the cathode, oxygen $\left(\mathrm{O}_{2}\right)$ and carbon dioxide $\left(\mathrm{CO}_{2}\right)$ are converted into carbonate ions. The electrolyte allows carbonate ions to migrate to the anode. At the anode, hydrogen reacts with carbonate ions to form water and $\mathrm{CO}_{2}$, and two electrons are released. Connecting the two electrodes through an external circuit completes the flow of electrons to generate DC electricity.

Molten carbonate fuel cell plants can achieve an electric efficiency of 50 percent, which is considerably higher than that of a phosphoric acid fuel cell plant.

Molten carbonate fuel cells can operate at 25 percent to 125 percent of the nominal plant rating. According to preliminary design data (EPRI 1992), a 2-MW molten carbonate fuel cell plant will have a footprint of $511 \mathrm{~m}^{2}\left(5,500 \mathrm{ft}^{2}\right)$ and can be configured for either outdoor or indoor installation. Molten carbonate fuel cells need more than 16 hours to reach rated output from a cold start. If kept on standby, it will take about one minute for the plant to reach full power output from idle.

Little external water is needed for molten carbonate power plant operations. The plant emits practically no particulates. $\mathrm{SO}_{x}$ and $\mathrm{NO}_{\mathrm{x}}$ emissions are extremely low. ${ }^{7}$

Solid Oxide Electrolyte Fuel Cells As the name implies, SOFC technology utilizes a solid oxide, usually doped zirconia, as the electrolyte. It operates at atmospheric or elevated pressures at a temperature of approximately $1000^{\circ} \mathrm{C}$. At this temperature, the electrolyte material becomes sufficiently conductive to oxide ions. The temperature of exhaust gases from the cells is $500^{\circ} \mathrm{C}$ to $850^{\circ} \mathrm{C}-$ a temperature which is attractive for cogeneration applications or for use in bottoming cycles for all-electric power plants.

${ }^{7}$ For a 2-MW molten carbonate fuel cell power plant, the estimated $\mathrm{SO}_{\mathrm{x}}$ emission is $0.003 \mathrm{lb} / \mathrm{MWh}$, and the $\mathrm{NO}_{\mathrm{x}}$ emission is $0.0004 \mathrm{lb} / \mathrm{MWh}$. 
The SOFC conducts oxygen ions $\left(\mathrm{O}^{2-}\right)$ from an air electrode (cathode), where they are formed, through a solid electrolyte to a fuel electrode (anode). There, they react with carbon monoxide (CO) and hydrogen $\left(\mathrm{H}_{2}\right)$ contained in the fuel gas to deliver electrons and produce electricity. Reformation of natural gas or other fuels containing hydrocarbons can be accomplished within the generator, thus eliminating the need for an external reformer. Individual cells are bundled into an array of series-parallel electrically connected cells forming a semi-rigid structure that comprises the basic generator building block.

There are several features of SOFC technology that make it very attractive for utility and industrial applications. One is high tolerance to fuel contaminants. The high temperature of the reaction does not require expensive catalysts and permits direct fuel processing in the fuel cells. The solid oxide electrolyte is very stable. Because no liquid phases are present in the electrolyte, many of the problems associated with electrode flooding, electrolyte migration, and catalyst wetting are avoided. Cell components of the solid oxide electrolyte fuel cell can be fabricated into a variety of self-supporting shapes and configurations that may not be feasible with fuel cells employing liquid electrolytes. This possibility may lead to very high power densities for the SOFCs.

Analyses and operations of experimental units have shown that an SOFC plant can achieve an electric efficiency of 50 percent. SOFC technology also has very low emissions. Because sulfur is removed from the fuel, no $\mathrm{SO}_{x}$ is emitted. The gas-impervious electrolyte does not allow nitrogen to pass from the air electrode to the fuel electrode, hence the fuel is oxidized in a nitrogen-free environment, averting: the formation of $\mathrm{NO}_{\mathbf{x}}$. The temperatures of exhaust gases are not high; this also helps reduce $\mathrm{NO}_{\mathbf{x}}$. $\mathrm{NO}_{\mathbf{x}}$ emissions measured at the testing plant have been fewer than $0.5 \mathrm{ppm}$ (Westinghouse 1992).

Several demonstration projects are underway. Commercial SOFC plant designs are expected to be available in the late 1990s. Table 2-7 lists fuel cell types and their characteristics.

Table 2-7. Fuel Cell Types and Characteristics

\begin{tabular}{lccc}
\hline & PAFC & MCFC & SOFC \\
\hline Electrolyte & Phosphoric Acid & Molten Carbonate & Solid Oxide \\
& $\mathrm{H}_{3} \mathrm{PO}_{4}$ & $\mathrm{LiKCO}_{3}$ & $\mathrm{Y}_{2} \mathrm{O}_{3}$ and $\mathrm{ZrO}_{2}$ \\
Operating Temperature & $200^{\circ} \mathrm{C}$ & $650^{\circ} \mathrm{C}$ & $1000^{\circ} \mathrm{C}$ \\
System Efficiency (\%) & $40 \%-45 \%$ & $50 \%-57 \%$ & $45 \%-50 \%$ \\
Btu/kWh & $8300-7000$ & $6800-6000$ & $7600-6500$ \\
Module Size & $200 \mathrm{~kW}$ & $250 \mathrm{~kW}-2 \mathrm{MW}$ & $100 \mathrm{~kW}$ \\
Fuel Type & Natural, coal, or landfill gas, etc. & \\
Commercial Availability & Now & 1997 & 2000 \\
\hline
\end{tabular}

\subsubsection{Status of Technology}

Several types of fuel cells exist in various stages of development (Hirschenhofer 1993). Phosphoric acid fuel cell technology has been commercialized, and utility-scale phosphoric acid fuel cells have been in operation since 1983. Small fuel cell power plants ranging between $50 \mathrm{~kW}$ and $500 \mathrm{~kW}$ are being used commercially for cogeneration at customer sites in Japan. Many commercial phosphoric acid fuel cell 
plants are operating successfully in the United States, and the numbers are increasing. Tokyo Electric Power Company is currently running an 11-MW phosphoric acid fuel cell plant, along with several smaller units.

EPRI and a number of utilities are focusing on the development of MCFC technology. Research is still required before this type of fuel cell can achieve its projected performance level. A 250-kW MCFC plant is currently being tested at Unocal Corp.'s research center in Brea, California. ${ }^{8}$ EPRI and the Fuel Cell Commercialization Group plan to complete a 2-MW MCFC demonstration plant (by Energy Research Corporation) by 1995 in Santa Clara, California. Commercial MCFC plants are expected to be available by 1997.

Westinghouse and DOE are developing SOFC technology. A pair of solid oxide fuel cells have operated continuously for 5 years in the laboratory with less than half a percent voltage degradation per 1,000 hours. In Japan, a prototype $20-\mathrm{kW}$ integrated SOFC generation system supplied by Westinghouse passed 6,000 hours of power production early in 1994. Utility demonstration of a 20-kW SOFC power generation plant in this country will begin in 1994. Testing for a $100-\mathrm{kW}$ unit is also expected to start in 1994.

The proton-exchange membrane (PEM) fuel cell is another developing technology. This type of fuel cell operates at less than $100^{\circ} \mathrm{C}$, and useful electric power can be drawn from the cell at room temperature. A $25-\mathrm{kW}$ proof-of-feasibility PEM fuel cell system commenced testing in 1993. PEM fuel cells are developed as a mid-term option for transportation applications under DOE's Fuel Cell Systems Research and Development Program (DOE 1994). Currently, there are no plans to develop this type of fuel cell for utility applications.

\subsubsection{Cost}

The ONSI 200-kW PAFC power plant is the only fuel cell generating unit commercially available today. Cost for the complete package is $\$ 750,000$, or $\$ 3,750 / \mathrm{kW}$. Production improvements and learning curve benefits are expected to reduce capital costs for the ONSI $200-\mathrm{kW}$ unit to $\$ 600,000$, or $\$ 3,000 / \mathrm{kW}$ for 1995 delivery. This is for a complete system delivered to the customer's site. ONSI expects the unit cost to drop to $\$ 450,000$, or $\$ 2,250 / \mathrm{kW}$, in 1997 and to $\$ 300,000(\$ 1,500 / \mathrm{kW})$ around 1999 . The average site preparation cost is about $\$ 75,000$.

No commercial carbonate fuel cell generating units have been installed. Based on the Santa Clara 2-MW Carbonate Fuel Cell Demonstration Project design, the estimated cost for a 2-MW MCFC plant in the year 2000 is $\$ 1,332 / \mathrm{kW}$ (1992 dollars) for an annual production rate of 200 units (Sandler and Farooque 1993). Annual fixed O\&M costs for the 2-MW carbonate fuel cell unit are estimated at $\$ 9.8 / \mathrm{kW}$. Variable O\&M costs are estimated at $1.7 \mathrm{mills} / \mathrm{kWh}$, excluding stack reloads (EPRI, 1992).

Commercially available PAFC plants do not require much maintenance. Routine maintenance, such as replacing air filters and water treatment beds, is needed every 3 to 6 months and can be performed without shutting down the power plant. Annual shutdown is required to inspect and replace a number of pressure vessels, relief valves, and pressure piping.

${ }^{8}$ Sponsored by DOE, EPRI, Gas Research Institute (GRI), South Coast Air Quality Management District, Southern California Edison Company, Southern California Gas Company, and Unocal. 
Fuel cell stack and fuel processor overhaul is required every 5 to 10 years. The schedule is determined by the duty cycle, gas composition, and operating environment of each unit.

Table 2-8 summarizes the major attributes of PAFC power plants that are relevant to DU applications.

Table 2-8. Attributes of PAFC Power Plant

\begin{tabular}{lr}
\hline NO $\mathrm{x}_{\mathrm{x}}$ Emissions: & $0.02 \mathrm{lb} / \mathrm{mmBtu}$ \\
Utility Grid Interface: & Yectronic Power Converter \\
Dispatchability: & Base Load \\
DU Application: & $1.0 \mathrm{~kW} / \mathrm{m}^{2}$ \\
Power Density: & $\$ 3,750 / \mathrm{kW}$ \\
Plant Costs (PAFC): & $\$ 0.0017 / \mathrm{kWh}$ \\
O\&M Costs: & \\
\hline
\end{tabular}

\subsection{Parabolic Dish Solar Thermal Generating System}

Parabolic dish solar thermal generating systems consist of parabolic shaped reflectors that concentrate solar energy onto a receiver mounted at the focal point of the reflector. The solar energy at the receiver can be utilized directly by a heat engine attached to the receiver, which drives a generator to produce electric energy. Or it can be converted into thermal energy in a circulating fluid, then piped to a central location for storage and further conversion. Parabolic dish systems that collect absorbed solar energy at individual receivers and deliver it via a heat-transfer fluid to a central storage and power conversion system are designed as central station utility power plants. Their operating characteristics are similar to those of the parabolic trough systems installed by LUZ International ${ }^{9}$ in southern California. Other parabolic dish systems that employ a heat engine at the focal point to produce electricity in the 5- to 25$\mathrm{kW}$ range are being developed for remote power and distributed generation applications. This type of parabolic-dish system is the focus of this section.

The reflectors concentrating the sunlight onto receivers may consist of many mirrored facets that form a large reflective area, or they may consist of one very large curved reflector. Mechanical tracking systems are used to aim the reflectors at the sun, allowing concentrators to reflect as much as 85 percent to 90 percent of the incident sunlight onto the receiver. Attached to the receiver and powered by the heat it supplies is the heat engine. The two most promising heat engine designs for mounting at the focal point appear to be the Brayton-cycle engine and the Stirling-cycle engine (De Laquil et al. 1993). These engines have high thermal efficiency at high operating temperatures. The balance of the system includes a drive train for tracking the sun, system controls, and power conditioning equipment.

Parabolic dish solar thermal generating systems have many attractive attributes. Among them are simplicity of operation, modularity, short lead time, potential long life, low maintenance, minimal water requirement, and high conversion efficiency. These attributes offer considerable planning and siting flexibilities to utilities. The conversion efficiencies of a parabolic dish with a Stirling engine are high compared to current PV technologies. A demonstration installation by Advanco Corporation of Beverly

\footnotetext{
${ }^{9}$ LUZ International is now defunct, but the plants are still operating.
} 
Hills, Califomia achieved a sunlight-to-electricity efficiency of 31.6 percent (gross)-the highest system efficiency achieved by any solar technology to date. ${ }^{10}$

\subsubsection{Performance}

The dish-Stirling system is designed to produce single-phase $60-\mathrm{Hz} \mathrm{AC}$ electric energy in quiet operations. The system in operation in Abilene, Texas has reached a peak solar-to-electric conversion efficiency of 29 percent at an operating temperature of $675^{\circ} \mathrm{C}$. The production units are expected to reach a peak solar-to-electric conversion efficiency of 32 percent. The range of annual load factor is estimated at 20 percent to 26 percent for a typical southwest United States site. System availability is expected to be 90 percent (Bean and Diver 1993).

Test data have indicated that parabolic dish-Stirling systems are reliable. Testing of three prototype McDonnell Douglas/United Stirling systems by Southern California Edison between 1986 and 1988 demonstrated system availability ranging between 50 and 87 percent. Major causes of reduced availability were circumstantial (loss of trained personnel, lack of spare parts, and testing) rather than hardwarerelated (Lopez and Stone 1992).

The dish-Stirling system uses direct beam radiation from the sun and has an output profile similar to that of a two-axis tracking PV concentrator system. Unlike PV arrays, which use electronic inverters to interface with the utility grid, dish-Stirling systems use conventional rotational electric generators to produce AC power directly. The system is not dispatchable by utilities unless a supplemental heat source is included.

\subsubsection{Status of Technology}

Several parabolic dish test facilities have been constructed and operated (De Laquil et al. 1993). DOE is collaborating with a private solar industry/electric utility consortium to develop and commercialize parabolic dish technology.

A free piston Stirling engine is currently being developed and tested by Sandia National Laboratories and Cummins Power Generation, Inc. The engine operates without mechanical linkages and uses gas bearings and clearance seals on the piston. The generator used in the dish-Stirling system is a permanent magnettype linear alternator, which is designed to produce $60-\mathrm{Hz} \mathrm{AC}$ at a constant voltage. Part of the current research efforts are to develop high-performance reflectors that are inexpensive, light, and easy to manufacture and maintain. Stretched membrane concentrators are currently the focus of considerable attention because they are most likely to achieve the goals of low production cost and adequate performance. Stretched membrane facets with edge-supported aluminized reflective polyethylene terephthalate (PET) film or thin stainless-steel sheet and glass mirrors are being tested. Both multifaceted and single-facet designs are being pursued.

A 5-kW concept validation dish-Stirling system has been operating in Abilene, Texas since June 1992. Researchers are improving the performance of stretched membrane reflectors, receivers, and the free piston Stirling engine. A 7.5-kW design by Cummins will be tested in 1994. Commercial units are planned for 1996 (DOE 1993). Science Applications International Corporation (SAIC) is developing a

${ }^{10}$ Individual PV cells have demonstrated even higher conversion efficiencies (sunlight to DC electricity), but the efficiency (sunlight to AC electricity) of current PV systems is lower because of modular and inverter losses. 
25-kW system with a Stirling engine by Stirling Thermal Motors and Detroit Diesel Corporation. Field tests of the $25-\mathrm{kW}$ system were scheduled to begin in late 1994. Market entry of this unit design is planned for 1998. Both systems employ multi-faceted, stretched membrane reflectors. A hybrid dishStirling system that includes a natural gas combustor as the supplemental heat source is also being developed. The hybrid system will give utilities more operating flexibility because it can generate electricity during cloudy days and during the night. Figure 7 shows a schematic of the Cummins $7.5-\mathrm{kW}$ parabolic-dish solar thermal generating system.

\subsubsection{Cost}

Commercial dish-Stirling systems are still under development. The estimated cost of a 7.5-kW dishStirling system is $\$ 28,500(\$ 3,800 / \mathrm{kW})$ in 1996 , which assumes an annual production rate of 10,000 units (Diver 1993). The design goal of the system is to have a major overhaul at 40,000 hours. The PET film reflectors in the concentrator are not expected to last as long as the rest of the dish-Stirling system. Periodic replacement of the mirrors may be necessary. Long-term performance of the collecting system has not been established. Maintenance cost is estimated at 2 percent of the installed cost per year by Cummins, not including the cost of mirror replacement. Estimated price for a complete SAIC 25-kW dish-Stirling system is $\$ 126,000(\$ 5,040 / \mathrm{kW})$ in 1998 based on annual production of 100 units. The steel and glass-mirror constructed reflectors in the SAIC system are designed to have the same service life as other components of the system, and they need little maintenance.

Table 2-9 below gives the projected cost and performance indicators of the parabolic dish Stirling system (De Laquil et al. 1993).

Table 2-9. Parabolic-Dish-Stirling System Cost and Performance Projections

\begin{tabular}{lccc}
\hline & $\mathbf{1 9 9 5 - 2 0 0 0}$ & $\mathbf{2 0 0 0 - 2 0 0 5}$ & $\mathbf{2 0 0 5 - 2 0 1 0}$ \\
\hline Assumed annual & $3 \mathrm{MW} / \mathrm{yr}$ & $30 \mathrm{MW} / \mathrm{yr}$ & $300 \mathrm{MW} / \mathrm{yr}$ \\
Production rate & & & \\
Capital cost & $3,000-$ & $2,000-$ & $1,250-$ \\
$\$ / \mathrm{kW}$ & 5,000 & 3,500 & 2,000 \\
Collector cost & $300-500$ & $200-300$ & $150-200$ \\
$\$ / \mathrm{m}^{2}$ & & & \\
Efficiency & $16 \%-24 \%$ & $18 \%-26 \%$ & $20 \%-28 \%$ \\
Capacity factor & $16 \%-22 \%$ & $20 \%-26 \%$ & $22 \%-28 \%$ \\
Annual O\&M cost & $0.05-0.025$ & $0.03-0.02$ & $0.025-0.015$ \\
$\$ / \mathrm{kWh}$ & & & \\
\hline
\end{tabular}

${ }^{1}$ For typical U.S. Southwest locations

\subsection{Summary}

The supply-side DU technologies discussed here offer a wide range of technical attributes and operating characteristics. Their costs also differ considerably. The feasibility of any DU application is obviously determined by the value of these technologies in a specific utility environment. The load characteristics, available land, local zoning ordinance, customer preference, and regulatory proceedings will all influence the final decision. Fossil-fuel based technologies such as engine/generator sets are compact and 


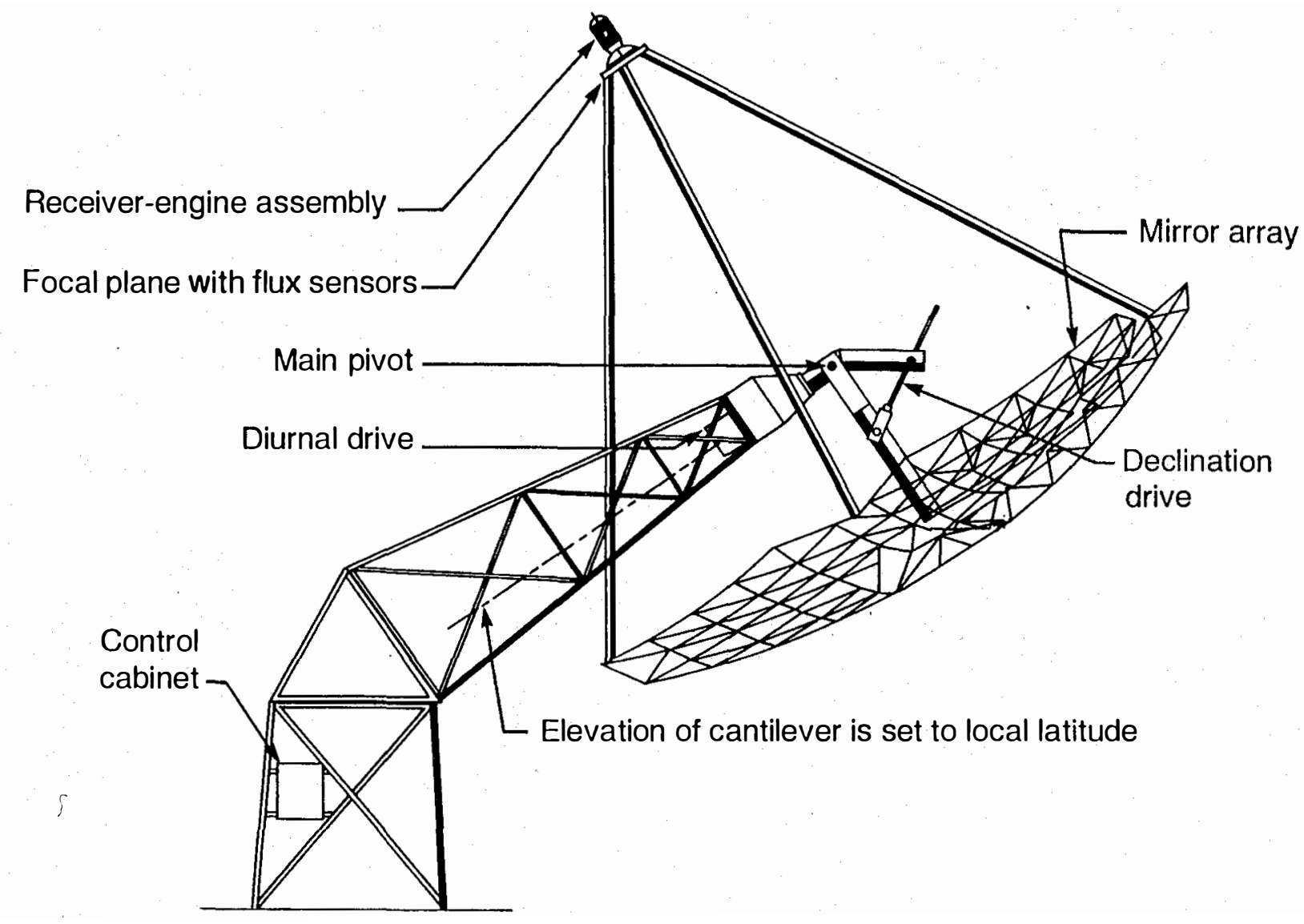

Figure 7. Schematic of a dish-Stirling system 
economical to install. Utilities are familiar with their operations. However, associated energy costs are subject to future fuel price fluctuations. Furthermore, as discussed in Section 4 of this report, regulations on emissions may severely restrict installation of fossil-fueled technologies in many areas. Renewable energy technologies, on the other hand, produce electric power without any emission or solid waste, and their energy costs will not be affected by the future fuel price uncertainties. Compared to fossil-fueled technologies, they also can be expected to have fewer siting constraints. Nevertheless, renewable energy technologies face obstacles related to load matching and non-dispatchability in DU applications. No single technology can fit every application, and thorough evaluation and planning are required in order to determine the optimal matches.

Table 2-10 summarizes the technical attributes and operating characteristics of selected modular technologies.

Table 2-10. Summary of Technical Attributes

\begin{tabular}{|c|c|c|c|c|c|c|c|}
\hline & $\begin{array}{l}\text { Engine } \\
\text { Genset }\end{array}$ & $\begin{array}{r}\text { Turbine } \\
\text { Genset }\end{array}$ & $\begin{array}{l}\text { Battery } \\
\text { (1-3 hrs) }\end{array}$ & $\begin{array}{l}\text { Fuel } \\
\text { Cells }\end{array}$ & PV & Wind & $\begin{array}{l}\text { Dish- } \\
\text { Stirling }\end{array}$ \\
\hline Conventional Interface & $\checkmark$ & $\checkmark$ & & & & & $\checkmark$ \\
\hline EPC ${ }^{1}$ Interface & & & $\boldsymbol{J}$ & $\checkmark$ & $\checkmark$ & $\sqrt{2}$ & \\
\hline Dispatchability & $\checkmark$ & $\checkmark$ & $\sqrt{3}^{3}$ & $\checkmark$ & & & $\sqrt{ }^{4}$ \\
\hline Load Following & $\checkmark$ & $\checkmark$ & $\checkmark$ & $\checkmark$ & & & \\
\hline Black Start & $\checkmark$ & $\checkmark$ & $\checkmark$ & $\checkmark$ & $\checkmark$ & $\checkmark$ & $\checkmark$ \\
\hline Capacity Range & $\begin{array}{r}50 \mathrm{~kW}- \\
5 \mathrm{MW}\end{array}$ & $\begin{array}{r}500 \mathrm{~kW}- \\
25 \mathrm{MW}\end{array}$ & $\begin{array}{r}250 \mathrm{~kW}- \\
20 \mathrm{MW}\end{array}$ & $\begin{array}{r}200 \mathrm{~kW}- \\
2 \mathrm{MW}\end{array}$ & $\begin{array}{l}1 \mathrm{~kW}- \\
1 \mathrm{MW}\end{array}$ & $\begin{array}{c}10 \mathrm{~kW}- \\
1 \mathrm{MW}^{5}\end{array}$ & $\begin{array}{r}7.5 \mathrm{~kW}- \\
25 \mathrm{~kW}^{5}\end{array}$ \\
\hline Efficiency $^{6}$ & $35 \%$ & $29-42 \%$ & $74 \%$ & $40-57 \%$ & $6-19 \%$ & $25 \%$ & $29 \%$ \\
\hline Energy Density $\left(\mathrm{kW} / \mathrm{m}^{2}\right)$ & 50 & 59 & $1.6 / 23.8$ & $1.0-3.0$ & 0.02 & $0.01^{7}$ & 0.04 \\
\hline Capacity Factor & $\sim 85 \%$ & $\sim 85 \%$ & $\mathbf{n} / \mathbf{a}$ & $\sim 90 \%$ & $11-40 \%$ & $23-38 \%$ & $12-22 \%$ \\
\hline Capital Cost $(\$ / \mathrm{kW})$ & $\begin{array}{r}200- \\
350\end{array}$ & $\begin{array}{r}450- \\
870\end{array}$ & $\begin{array}{r}830- \\
1,080\end{array}$ & 3,750 & 6,600 & 1000 & 3,800 \\
\hline O\&M Cost $(\$ / k W h)^{8}$ & 0.01 & $\begin{array}{l}0.005- \\
0.0065\end{array}$ & 0.0076 & 0.0017 & $\begin{array}{r}0.001- \\
0.004\end{array}$ & 0.01 & $\begin{array}{l}0.05- \\
0.025\end{array}$ \\
\hline $\mathrm{NO}_{x}(\mathrm{lb} / \mathrm{mmBtu})$ & $\begin{array}{r}2.76 \text { to } \\
3.1\end{array}$ & 0.61 & $\mathbf{n} / \mathbf{a}^{9}$ & $\begin{array}{r}0.003 \text { to } \\
0.02\end{array}$ & $\mathbf{n} / \mathbf{a}$ & $\mathbf{n} / \mathbf{a}$ & $\mathbf{n} / \mathbf{a}$ \\
\hline Technology Status & Comm. & Comm. & Comm. & $\begin{array}{r}\text { Comm. \& } \\
\text { Demo. }\end{array}$ & Comm. & Comm. & Demo. \\
\hline
\end{tabular}

Notes: 1. Electronic power converter

2. For variable speed wind turbines

3. When fully charged

4. With supplement heat from natural gas burner

5. Individual unit, plant size can be much larger

6. Efficiencies of renewable energy technologies should not be compared directly with those of fossil technologies, since the fuel is unlimited.

7. Based on windfarm of normal $10 \mathrm{D}$ by $5 \mathrm{D}$ spacing

8. Excluding fuel cost

9. Extra energy from other sources needed due to charging-discharging losses. 


\subsection{Demand-Side Distributed Utility Technology Options}

Demand-side management (DSM) is a category of utility activities designed to influence customer use of electricity in ways that will produce desired changes in utility load shapes and promote the cost-effective use of energy efficient devices. DSM provides utilities with a viable alternative to the traditional approach of expanding generating capacity to meet increasing electricity demand. Utilities implement DSM programs to meet many different objectives, such as minimizing long-term capital investment, remedying short-term capacity shortages, improving operational efficiency, and strategic energy conservation. Extensive DSM experience has been accumulated by utilities over the past decade. More recently, utilities have started to examine the DSM programs as an alternative to T\&D upgrade (EPRI 1992).

DSM is typically divided into three basic classifications: energy efficiency programs, direct load control, and rate designs. Energy efficiency programs-including energy audits, building insulation, efficient appliance and lighting, and options for heating, ventilating, and air conditioning (HVAC) - are the types of DSM programs that do not require direct utility interaction with customers following implementation. These programs can achieve substantial capacity and energy impacts, but the host utility has little control over the timing or magnitude of impacts after implementation. Direct load control of selected customer loads or of a specific end-use device is another type of DSM program. This kind of DSM program is usually implemented in conjunction with some form of rate incentive which allows the utility to have an active role in directly altering end-use patterns. Rate designs, such as time-of-use rates, interruptible rates, real-time pricing, etc., comprise the remaining DSM programs. These require active, ongoing utility-customer interaction. Utilities can design such programs to tailor the timing and magnitude of load impacts with system conditions.

In the past, most utility DSM programs were designed to achieve two interrelated objectives: (1) reducing peak demand to delay major additions to generating capacity, and (2) reducing electricity use to conserve energy. Many measures that reduce peak demand also lower consumption of electricity during off-peak periods. Typically, DSM programs are evaluated according to their impacts on the generation system. For DU applications, these evaluations are not adequate because a good capacity match with the system peak does not necessarily correspond to a match with the local feeder peak. To qualify for DU benefits, a DSM program must be able to reduce the peak demand of the targeted local areas in addition to the system peak.

The subject of DSM is well defined at most utilities. Manuals and computer software are available to estimate the energy savings and reduction in demand realized through DSM programs. The reliability of DSM programs should be evaluated carefully when they are implemented to accomplish additional T\&D goals. DSM impacts on service reliability should be considered and compared to the impacts of other T\&D alternatives.

This section discusses several common DSM techniques in the context of three end-use categories: commercial, residential, and industry technology. Only energy efficiency and direct load control programs are included. In selecting DSM programs to discuss, priority was given to those with greater effects on peak demands. Targeted DSM programs for DU applications must be able to alter the peak demand to realize additional T\&D benefits, and the programs listed in this report represent those that will have a more significant impact on feeder demand. It is not meant to be a complete reference of DSM technologies. Rather, the purpose of this section is to provide a starting point for utility planners and engineers in evaluation and screening of the available DSM technologies, and to provide guidance in finding the programs that are most likely to be effective in the DU application. Applicability and 
effectiveness of DSM programs depends on system load characteristics and utility strategies, but it should be clear that other DSM techniques not included in this report can also apply in the DU environment.

The cost information included in this section for DSM technologies are technology costs, not the program cost. Technology costs are used in screening program alternatives and for preliminary economic analyses. The value of DSM programs is too utility-specific to derive a general $\$ / \mathrm{kW}$ cost figure for selected DSM technologies, and available DSM literature does not use the $\$ / \mathrm{kW}$ standard as a figure of merit for DSM programs. The market determines the cost of any specific DSM technology (e.g., a 25-W compact fluorescent light bulb costs about $\$ 15$, or a high-efficiency air conditioning system costs about $\$ 650$ per ton, etc.). The $\mathrm{kW}$ reduction from a particular DSM technology, however, is dependent on customer usage patterns, technologies to be replaced, and overall utility load characteristics. Furthermore, technology cost is only part of the total program costs. Utility costs of DSM programs usually include the expenses associated with administration, advertising, and rebating. DSM impacts on utility revenues also need to be considered in designing the DSM program. Regulatory processes at the state level usually determine these costs and the overall program costs.

\subsection{Commercial DSM Technology Options}

The commercial sector offers greater opportunities for load growth, energy conservation, and load management than any other sector of the economy (EPRI 1988). Advances in building design and enduse technology have enhanced the attractiveness of electricity to commercial sector customers. The growth rate of electricity in the commercial sector far exceeds all other energy forms, even though the overall consumption of energy in new commercial buildings has decreased in the last decade.

Three commercial DSM technology categories are discussed in this section: efficient HVAC, lighting, and commercial refrigeration.

\subsubsection{Efficient HVAC Options}

Efficient HVAC system options allow end users to satisfy their needs while reducing energy costs. Many of these options offer energy conservation benefits, in addition to peak-clipping benefits. HVAC systems account for about 39 percent of the electric energy consumed in commercial buildings (EPRI TAG - End Use 1992). This is the largest use of electricity in the commercial sector. Various options exist for new HVAC installations and retrofits.

High-efficiency Air Conditioning Air conditioning in larger commercial buildings is normally component-based and custom engineered. Increased energy savings and demand reduction can be achieved by designing and installing high-efficiency air-conditioning systems for new buildings. The cost range for a 30-ton, high-efficiency system is between $\$ 550 /$ ton and $\$ 750 /$ ton (WAPA 1991). For existing systems, cooling system maintenance, such as cleaning the condensers, changing filters, oiling the bearings, and fixing refrigerant and air duct leaks, can result in demand reductions up to 15 percent. (EPRI 1992). Costs for air conditioning tune-ups vary, depending on the extensiveness of required duct

repair work. For a routine service job, this cost is estimated in the range of $\$ 165$ to $\$ 290$ per site (EPRI 1992).

Heat Pump Both air-source and closed-loop water heat pumps are applicable in commercial buildings. A closed-loop water heat pump provides year-round space conditioning through "balanced heat recovery." Internal heat gains are collected and redistributed to meet immediate heating requirements in the building perimeter zones, or they are stored in the form of warm water for future use. Supplemental heat can be provided from storage or from an external source. During the cooling season, cool water can also be 
stored to help reduce cooling demand during peak demand periods. These systems can reduce demand and energy consumption with or without storage.

A water-loop heat pump system typically uses a two-pipe closed loop supply-and-return circuit that circulates continuously at a temperature between $15.6^{\circ} \mathrm{C}$ and $32.2^{\circ} \mathrm{C}\left(60^{\circ} \mathrm{F}\right.$ and $\left.90^{\circ} \mathrm{F}\right)$. During warm weather most or all of the units in a building operate in the cooling mode, removing heat from the conditioned space and transferring it to the water loop. If heat needs to be rejected, a cooling tower or other equipment is used. During cold weather, most perimeter units will operate in the heating mode, transferring heat from the water loop to the conditioned spaces. The units in the core areas will most likely still operate in the cooling mode, adding enough heat to the water loop to meet perimeter-area heating requirements. When the water temperature falls below a specified level, heat is added to the loop from thermal storage or from a supplemental source to maintain the set loop temperature.

The installed cost of an air-source split system heat pump typically ranges from $\$ 850 /$ ton for a 20 -ton unit to $\$ 1,300 /$ ton for a 2 -ton unit. For a single packaged system, the cost is about $\$ 50 /$ ton to $\$ 100 /$ ton less. The installed cost of water-loop system heat pump system is generally about $\$ 1,500 /$ ton .

Ground source heat pumps-or geothermal heat pumps, as they are also called-are water-loop heat pump systems that use the ground both as a heat source (for heating) and sink (for cooling). This system takes advantage of the relatively constant temperature (about $5^{\circ} \mathrm{C}$ to $21^{\circ} \mathrm{C}\left[40^{\circ} \mathrm{F}\right.$ to $\left.70^{\circ} \mathrm{F}\right]$ ) immediately beneath the ground's surface (EPRI 1988). A ground source heat pump system consists of an heat exchanger for heating and cooling a building and a loop of pipe extending vertically or horizontally into the ground. The U.S. Environmental Protection Agency concluded in a 1993 study that ground source heat pumps are consistently the most energy-efficient and environmentally clean space-conditioning systems among the competing technologies (L'Ecuyer et al. April 1993). Depending on the location and climate, the high efficiency of ground source heat pumps can reduce energy consumption by 23 percent to 44 percent over air source heat pumps and by 63 to 72 percent over electric resistance heating and conventional airconditioning equipment (Lienau 1994). The installed cost per ton for ground source heat pump systems ranges from $\$ 750$ to $\$ 2,000$, depending on soil conditions (Sullivan 1994).

\subsubsection{Efficient Lighting}

Lighting accounts for approximately 37 percent of commercial building electricity use (Brookhaven National Laboratory 1987). Electricity consumption attributed to lighting is even higher if the air conditioning loads that handle the internal heat generated by the lighting systems are included in those figures. ${ }^{1}$ Lighting represents a major opportunity for improvements in efficiency and power demand reduction. High-efficiency lamps and ballasts, improved lighting fixtures, proper lighting levels, and increased use of natural day lighting can all contribute to substantial reductions in power demand for lighting.

The impact of lighting on electric energy use and power demand is specific to any given building. Lighting interacts with other energy-related equipment in buildings, especially the HVAC systems. Lighting will increase building air conditioning loads, but can also be an internal heat source, which offsets space-heating requirements. Common efficient lighting options are discussed below. However,

${ }^{1}$ In daylight-limited environments as much as one-half the air-conditioning loads may come from the lighting systems (New York State Energy R\&D Authority 1991). However, the reverse is also true: reduction in electricity consumption from efficient lighting will increase the need for heating energy. 
efficient lighting is more than just replacing lighting fixtures and lamps. Careful planning and design also play a critical role in achieving demand reductions and energy savings in lighting systems.

High-intensity Discharge (HID) Lamps Metal halide, and high- and low-pressure sodium lamps are examples of HID lamps. Low-pressure sodium has the highest efficacy ${ }^{2}$ of any lighting technology in the marketplace, but very poor color rendition. High-pressure sodium lamps have the second highest efficiency and provide acceptable color rendition for street lighting, parking garages, and commercial applications (for example, warehouses, shopping malls, and display halls). Metal halide has lower efficacies than high- and low-pressure sodium, but offers better color rendition properties.

When replacing existing fluorescent and incandescent lamps with high- and low-pressure sodium lamps, the existing lighting fixtures have to be replaced too. In addition, repositioning of the fixture is suggested to maximize efficiency and reduce the retrofit cost. High- and low-pressure sodium lamps can directly substitute for metal halide lamps without changing out lighting fixtures. Compact versions of metal halide lamps can be substituted for incandescent lights.

Fluorescent Lamps Retrofits to lighting systems save cooling energy as well as lighting energy. One kilowatt-hour of lighting input produces $3400 \mathrm{Btu}$ of heat. Depending on the type of lighting fixture, between 60 percent and 80 percent of this heat appears as a room load. The remainder is rejected from the ballast and top surface of the lighting fixture into the ceiling plenum air space. Reducing the power for lighting will reduce the sensible cooling load in the room, but increase heating loads slightly. Efficient lighting can usually achieve significant reductions in cooling equipment and its capital and operating costs.

Today's advanced technology fluorescent lamps offer high efficiency and high color rendering compared with the conventional 122-cm (4-foot), T-12 lamps that have long been the standard in the fluorescent lamp market. These improved lamps (T-8 type) can save 15 percent to 20 percent of the wattage used by standard fluorescent lamps. When installed with an electronic ballast, they provide 98 percent as much light as standard lamps and use about 40 percent less energy.

When replacing standard fluorescent lamps with efficient T-8 lamps, it is necessary to replace the existing ballast with an electronic ballast. Electronic (solid-state) ballasts reduce flicker and improve ballast/lamp system efficiency by 24 percent to 25 percent over standard electromagnetic ballasts. As a result, they are $30^{\circ} \mathrm{C}\left(86^{\circ} \mathrm{F}\right)$ cooler than standard ballasts. Cooler operation also helps extend the life of electronic ballasts. Additional benefits include less weight and quieter operation. However, electronic ballasts can increase harmonic distortion of the power supply circuit.

Compact fluorescent lamps represent another option for efficient lighting in the commercial sector. A compact fluorescent lamp uses approximately one-third the energy of a standard incandescent light bulb to produce an equivalent light output. Although incandescent light bulbs serve only 20 percent of commercial lighted floor space, they account for nearly 40 percent of commercial lighting energy use. Compact fluorescent lamps last about ten times longer than do standard incandescent bulbs. This option is best suited for heavily used lighting fixtures that operate for extended periods, such as hallway and stairwell lamps.

${ }^{2}$ Efficacy is the measure of efficiency of a light source to convert electric power in watts into visible light in lumens and is expressed in lumens per watt. The higher the efficacy, the less electric energy is required to achieve a given illumination level. 
In some situations, specular reflectors can increase the efficiency of a typical lighting fixture by reflecting additional light onto the work area. Specular reflectors have mirror-like characteristics that reduce absorption of light within the fixture. Using specular reflectors makes it possible to remove half the existing fluorescent tubes with a minimal reduction in light levels. Specular reflectors installed with energy-efficient fluorescent lamps and electronic ballasts can reduce lighting energy as much as 65 percent.

Table 3-1 summarizes efficient lighting options.

Lighting Controls Lighting controls modify fixture output based on the quantity of light needed. When integrated with efficient fixtures, the resulting lighting system can achieve significant demand reductions and energy savings (LBL 1989). Lighting control strategies include static controls that decrease lighting levels by a predetermined amount and dynamic controls that turn lamps on and off or dim them in response to changes in daylighting or occupant needs. Lighting controls devices range from simple manual switches to timers, various dimmer switches and sensors. Costs of these devices range from a few dollars for a dimmer switch to about $\$ 90$ to $\$ 105$ for an ultrasonic occupancy sensor. Wiring and labor may add approximately $\$ 35$ to $\$ 50$ per retrofit installation.

\subsubsection{Commercial Refrigeration Systems}

About 9 percent of the electricity consumed in the commercial sector is used for commercial refrigeration. Of that amount, approximately 70 percent is used by retail operations such as food stores and supermarkets. Energy efficiency enhancements to conventional multiplex refrigeration systems include floating head pressure (which allows the compressor-discharge pressure and therefore the temperature to drop when ambient air temperature drops, resulting in increased efficiency), ambient subcooling, mechanical subcooling, evaporative condensers, hot gas defrost, and heat reclaim. Proper application of state-of-the-art commercial refrigeration systems can reduce refrigeration system peak demand and energy requirements by 20 percent to 30 percent (EPRI 1989).

Conventional refrigeration systems have installed costs that average $\$ 800$ to $\$ 1,000$ per refrigeration ton or $\$ 500$ to $\$ 625$ per compressor nameplate horsepower. A typical large supermarket of approximately $3,750 \mathrm{~m}^{2}\left(40,000 \mathrm{ft}^{2}\right)$ may have 50 to 70 refrigeration tons of capacity, a combined compressor nameplate input of 80 to 115 horsepower, plus additional power inputs for evaporator fans, mullion heaters, and other equipment (EPRI TAG - End Use 1992).

\subsection{Residential DSM Technology Options}

Residential DSM programs encompass a broad range of utility/customer interactions that create customer options for managing energy consumption. Common residential DSM technologies can generally be classified into three categories: building weatherization options, efficient appliance and equipment options, and direct load management options. Some of the potentially more useful options under each category are discussed here. It is obvious that this set of options does not include all possibilities. Rather, it is a representative compilation of the most common approaches by utilities. Additional options can be implemented to achieve load shape objectives, depending on site-specific conditions and load characteristics. 
Table 3-1. Lighting Systems

\begin{tabular}{|c|c|c|c|c|c|}
\hline & $\begin{array}{l}\text { Conventional } \\
\text { Incandescent }\end{array}$ & $\begin{array}{r}\text { Full Size } \\
\text { Fluorescent }\end{array}$ & $\begin{array}{l}\text { Compact } \\
\text { Fluorescent }\end{array}$ & $\begin{array}{r}\text { Metal } \\
\text { Halide }\end{array}$ & $\begin{array}{r}\text { High-pressure } \\
\text { Sodium }\end{array}$ \\
\hline Lamp wattage & $40-500$ & $15-215$ & $5-39$ & $250-1,500$ & $100-1,000$ \\
\hline Lamp/ballast wattage & & & $5-40$ & $300-1,600$ & $120-1,100$ \\
\hline Lumens rating, initial & $400-10,000$ & $700-15,000$ & $250-3,150$ & $20,000-150,000$ & $10,000-140,000$ \\
\hline $\begin{array}{l}\text { Lamp efficacy, initial } \\
\text { (lumens/watt) }\end{array}$ & $10-20$ & $45-90$ & $25-85$ & $80-100$ & $100-140$ \\
\hline $\begin{array}{l}\text { Lamp/ballast efficacy, } \\
\text { initial (lumens/watt) }\end{array}$ & & $\begin{array}{r}65-80 \text { (magnetic) } \\
75-95 \text { (electronic) }\end{array}$ & $25-80$ & $70-95$ & $80-130$ \\
\hline $\begin{array}{l}\text { Average life } \\
\text { (hours) }\end{array}$ & $750-2,000$ & $10,000-24,000$ & $10,000-20,000$ & $8,000-10,000$ & $20,000-24,000$ \\
\hline Color Rendition Index ${ }^{1}$ & 100 & $90-50$ & $70-50$ & $80-65$ & $85-65$ \\
\hline Lamp cost, $\$$ each & $\begin{array}{r}0.5-1.50 \text { (to } 100 \mathrm{~W}) \\
\$ 0.01-0.015 / \mathrm{W}(>100 \mathrm{~W})\end{array}$ & $2-8$ & $\begin{array}{r}15-30 \\
\text { (integral lamp/ballast) }\end{array}$ & $\begin{array}{l}35-45 \text { (to } 400 \mathrm{~W}) \\
70-80(>400 \mathrm{~W})\end{array}$ & $\begin{array}{r}35-45 \text { (to } 400 \mathrm{~W}) \\
110-130(>400 \mathrm{~W})\end{array}$ \\
\hline Ballast cost, $\$$ each & & $\begin{array}{l}15-25 \text { (magnetic) } \\
25-35 \text { (electronic) }\end{array}$ & & $\begin{array}{r}80-120 \text { (to } 400 W) \\
200-220(>400 W)\end{array}$ & $\begin{array}{l}120-220 \text { (to } 400 \mathrm{~W}) \\
300-330(>400 \mathrm{~W})\end{array}$ \\
\hline $\begin{array}{l}\text { Lighting fixtures, } \\
\$ \text { each }\end{array}$ & $5-40$ & $40-70$ & $4-40$ & $100-150$ & $100-150$ \\
\hline \multicolumn{6}{|l|}{ Installation costs, $\$$ each } \\
\hline Fixtures & $30-60$ & $50-150$ & $30-60$ & $50-100$ & $50-100$ \\
\hline Wiring & $400-600^{2}$ & $400-600^{2}$ & $400-600^{2}$ & $100-300$ & $100-300$ \\
\hline
\end{tabular}

Source: EPRI TAG - End Use, 1992, WAPA DSM Pocket Guidebook, 1991, CEC Advanced Lighting Guidelines, 1990

${ }^{1}$ Color rendition index (CRI) is a scale from 1 to 100 that measures lamp color rendering - an expression for the effect of a light source on the color appearance of objects in comparison with their color appearance under a reference light source. The higher the number, the better the lamp's color rendering properties.

${ }^{2}$ Costs in $\$ / \mathrm{kW}$ 
In general there are few inherent motivations for residential customers to control, or allow utilities to control, their use of appliances beyond normal comfort levels. Some form of incentive may be required. Key factors for effective utility residential DSM programs are careful selection of suitable materials, equipment, and qualified installers. These factors emphasize the importance of careful program screening by utilities.

\subsubsection{Efficient Appliance and Equipment Options}

Efficient appliance and equipment options allow residential customers to meet end use demands with less energy. These options offer strategic conservation benefits to utilities because they use less energy than the appliances and equipment they replace. Some also offer peak clipping benefits because their demands are lower than less efficient devices. A range of high-efficiency appliance and equipment options are available. Some of these are described below.

Energy-Efficient Refrigerators and Freezers Refrigerators and freezers constitute a major residential end use of electricity. For example, in the PG\&E service territory, refrigerators account for 22 percent of residential electrical consumption; freezers account for 6 percent. New refrigerators are much more efficient than older models. The energy use of models sold in 1983 is approximately $1200 \mathrm{kWh} / \mathrm{yr}-30$ percent less than the models sold in 1971. In 1990, the best mass-marketed automatic defrost refrigerator/freezer models used about $750 \mathrm{kWh}$ per year. Refrigerators that meet $1993 \mathrm{U} . S$. minimum appliance efficiency standards (and the similar 1992 California standards) use about 30 percent less energy than previous models. As a result of these standards, full-size automatic defrost refrigerator/freezers (22 $\mathrm{ft}^{3}$ ) using less than $700 \mathrm{kWh}$ per year have been made available, and peak demand has dropped from about $1.5 \mathrm{~kW}$ to about $0.8 \mathrm{~kW}$.

Installation of high-efficiency refrigerators and freezers can reduce residential peak power demand and energy usage. However, customers' increasing tendency to select larger units may offset peak demand reduction effects. If customers retain the original refrigerators for additional food storage, as often happens, load reduction benefits are lost.

Energy-Efficient Air Conditioning An air conditioner provides space cooling and dehumidification using a vapor compression refrigeration cycle to remove indoor heat and reject it to the outdoors. There are two main types of air conditioners for residential application: window units and central systems. Central systems require an air duct system to carry the cool air to the entire house. Window units are placed in a window or wall, and may only cool one part of a house. Central air conditioning is now being installed in about 70 percent of all new single family homes in the United States.

The average seasonal energy-efficiency ratio $\left(\mathrm{SEER}^{3}\right)$ of central air-conditioning systems sold in 1988 was 8.0. The National Appliance Energy Conservation Act requires a minimum efficiency of 10.0 SEER for all split-system central air conditioners manufactured after January 1, 1992 and 9.7 SEER for all packaged units manufactured after January 1, 1993. The most efficient systems on the market have SEER ratings in the 12.0 to 15.0 range.

Air-conditioning system tune-up (adjusting charge, cleaning condensers, replacing filters, and adjusting airflows) and duct repair can reduce air-conditioning power demand. Demand reduction ranges from 6

${ }^{3}$ SEER is a ratio calculated by dividing the total seasonal cooling requirement (in Btu) by the total seasonal energy input (in $\mathrm{kWh}$ ), expressed as Btu per watt hour. It is an indication of the efficiency of air-conditioning equipment. 
percent for system tune-up to 14 percent for duct repair. The estimated average cost for a residential airconditioning tune-up is $\$ 140$ (EPRI 1992).

Domestic Water Heaters Water heating is the second largest user of energy in the residential sector, accounting for almost 20 percent of the total residential end-use energy consumption in the United States. Water heater retrofit programs are frequently used in the DSM strategies of electric utilities for the following reasons:

- A significant portion of residential customers use electricity to heat water

- Low-cost measures are available to reduce energy requirements for water heating

- Residential water heaters are amenable to load control because of their relatively large storage capacity.

Several water heating retrofit strategies are available. The most simple and cost-effective measure is water tank insulation. Heat-pump water heaters and solar water heaters are two additional options for retrofitting or replacing existing water heaters to reduce the energy consumption. Finally, domestic water heaters can also be directly controlled and cycled by utilities.

Water Tank Insulation: Older residential water heaters typically were manufactured with R-3 insulation in the tank walls. Newer water heaters are insulated to R-16. If the existing water heater is an older model, the insulation can be increased to save energy by wrapping a water heater blanket around the tank. The energy savings from additional tank insulation will vary based on how well the existing tank is insulated, the size of the hot water tank, and the hot water temperature settings. Estimated energy savings from adding two inches of insulation to a 380-liter (100-gallon) hot water tank with a $48.9^{\circ} \mathrm{C}$ $\left(120^{\circ} \mathrm{F}\right)$ temperature setting is about $368 \mathrm{kWh}$. Water heater blanket kits range in price from $\$ 20$ to $\$ 30$.

Solar Water Heaters: Solar water heating systems can be designed to operate in nearly any climate. The performance of a solar water heating system varies based on the amount of solar radiation incident on the collectors and on the outdoor temperature. In most parts of the country, solar water heating systems are designed to meet 100 percent of a home's hot water requirements during the summer months. The system may meet only half the home's hot water requirements in the winter months. A backup water heater is necessary to supplement the solar system during winter.

Active solar water heating systems use pumps to circulate water or some other heat transfer fluid from the collector, where it is heated by the sun, to the storage tank. Passive solar water heaters do not have pumps or other moving mechanical parts, so very little or no maintenance is required over the life of the system.

Incandescent Lamp Alternatives Lighting accounts for about 15 percent of the typical residential customer's electrical energy consumption. It is a relatively small load per household, and its contribution to the system peak demand usually is low. The large number of residential customers and the universal use of electric lamps, however, make efficient lighting an option for energy conservation and potential load growth management. New lighting products can offer significant energy savings over standard incandescent lamps. The use of fluorescent lamps in place of incandescent lamps, for example, can triple lighting efficiency. Another option is directly replacing standard incandescent light bulbs with compact fluorescent lamps. A compact fluorescent lamp uses approximately one-third the energy of a standard incandescent light bulb to produce an equivalent light output. Compact fluorescent lamps last about 10 times longer than do standard incandescent bulbs. This option is best suited for lights that are not turned on and off frequently. Customer acceptance of energy efficient lighting is uncertain because of the added costs of efficient lamps and replacement fixtures and the relatively small energy savings. Costs for 
compact fluorescent lamps for direct replacement of standard incandescent lamps range from $\$ 15$ to $\$ 30$ each.

\subsubsection{Direct Load Management Options}

A number of DSM options can be categorized as managing interruptible or curtailable loads. Their common characteristic is that they involve the direct control of customer loads by utilities. Direct load control actually alters the operation patterns of a customer's appliance. The purpose is to change the maximum demand, or the timing of individual loads, to meet system needs. The majority of residential and commercial direct load management programs involve air conditioners, water heaters, space heaters, and irrigation pumps. Industrial direct load management programs usually come in the form of curtailable loads. Direct load management options let utilities alter part of their loads directly, and they offer more flexibility in shaping utility loads to fit system needs. These types of direct load management programs are considered dispatchable, and they are short lead-time, reliable resources for utilities.

Time-of-use rates and real-time pricing rates are two examples of non-dispatchable direct load management options. They provide economic price signals to customers to discourage on-peak energy usage and encourage load shifts.

Direct load management options are designed to reduce peak demand through forced diversity of customer loads. Careful considerations must be given to design of the control strategy in order to actually clip the peak demand, instead of merely shifting it to a different time.

Domestic Water Heater Cycling Control Domestic water heater cycling control entails direct utility control over the operation of residential water heaters. It is usually implemented through a communication link between utilities and the water heater at the customer's site. By directly controlling and cycling water heaters, the utility can vary when and how much control is exercised, depending on the need. Water heating is one of very few residential loads that is truly deferrable, because a water heater can be turned off for an extended period without affecting the customer's lifestyle. Typical peak demand reduction resulting from water heater cycling is $1 \mathrm{~kW}$ per water heater with a range of $0.3 \mathrm{~kW}$ to $1.6 \mathrm{~kW}$. Hardware costs for a water heater cycling system with a communication link range from $\$ 50$ to $\$ 100$ per unit. Installation costs will add $\$ 15$ to $\$ 50$ per water heater.

Air-Conditioning Cycling Control Air conditioning cycling involves direct, real-time utility control over the operation of residential air conditioners. The peak demand for a typical residential air conditioner is approximately $1.5 \mathrm{~kW} /$ ton. The standard method of intentional cycling is to shut off the compressor for some fixed period, allow it to resume operation for some fixed period, and then shut it off again. A 25 percent cycle- 7.5 minutes off and 22.5 minutes on-is a typical cycling strategy.

Air conditioning cycling is generally implemented on central air conditioning systems or large throughthe-wall air conditioners. Small window units are rarely cycled. Cycling significantly undersized units can result in excessive customer discomfort, and cycling oversized units can result in little or no load relief. Costs of air conditioning cycling systems and controls are similar to those of water heater cycling systems. Reduction in peak demand depends on the cycling strategies used. Utilities with air conditioning control programs have reported demand reductions of $0.6 \mathrm{~kW}$ to more than $2 \mathrm{~kW}$ per residential installation. A typical value for demand reduction is $1 \mathrm{~kW}$ per unit. Since air conditioning is highly weather-sensitive, weather elements such as temperature and humidity will impact the potential for demand reduction. 
Curtailable Load Under the curtailable load agreement, customers receive a discount in their electricity rates in return for reducing their electric load to a predetermined level when utilities request it. Utilities usually tie the request for load curtailment to their system needs.

\subsection{Industrial DSM Technology Options}

Industrial loads are significantly more concentrated than residential or commercial loads for many utilities. Often, 2 percent to 10 percent of a utility's industrial customers account for up to 80 percent of electricity consumption. Typical industrial DSM measures include the following:

- High-efficiency motors

- Adjustable speed drives

- Matching motor size to load

- Eff́ective compressor application

- Heat recovery opportunity screening.

Industrial customers' main objective with DSM programs is energy conservation. Peak demand reduction is possible, and usually comes in the forms of work schedule changes and interruptible loads. DSM technology options for the industrial sector are usually specific to particular processes and production operations. The uniqueness of these industrial customers requires a careful case study approach to DSM options and evaluation at the individual plant level. 


\subsection{Environmental Characteristics and Siting Considerations}

Environmental factors will play a large role in determining the feasibility of DU implementations. Several DU technologies may derive additional benefits from their environmental attributes, and DSM or renewable energy technologies may be preferred over fossil-fueled technologies because of their reduced emissions. However, environmental considerations such as siting restrictions brought on by land requirements and aesthetic objections may become constraints and limit implementation of these technologies.

Many federal and state laws govern the siting and permitting processes of new energy facilities, including DU technologies. This section lists and describes some salient regulations and their implication in siting and permitting. Several actual utility experiences in siting and permitting distributed technologies are discussed to illustrate the processes. Each case involved a slightly different set of requirements.

\subsection{Summary of Environmental Regulations Affecting DU Technologies}

Analysis of a utility system to determine beneficial locations for the application of DU technologies must include consideration of the environmental regulations that will affect the physical placement of the technology. There are a myriad of federal, state, and local environmental laws that can influence the ultimate determination. The intent here is not to rigorously outline each law, but to briefly illuminate the most important regulations and the degree to which they may affect the DU technologies discussed.

\subsubsection{Federal Regulations}

Several federal laws and regulations can affect the siting and operation of electrical generation technologies, regardless of whether they are central station or distributed. Their major provisions follow.

Clean Air Act The Clean Air Act (1963) and Clean Air Act Amendments (1965, 1967, 1970, 1977, and 1990) established federal regulations for air pollutants (Lock et al. 1991). The Clean Air Act Amendments (CAAA) affect both mobile and stationary sources. One of the primary goals of the CAAA is to reduce concentrations of criteria air pollutants to a level below the National Ambient Air Quality Standards (NAAQS) in areas where those standards are exceeded. CAAA also is designed to prevent the air quality in areas that already meet the NAAQS from deteriorating and to limit the amount of hazardous air pollutants that are released to the environment. CAAA places responsibility for achieving the NAAQS with the states. Each state must formulate a State Implementation Plan (SIP) outlining how the state plans to achieve the NAAQS. The SIP must be approved by the U.S. Environmental Protection Agency (EPA). Rules and standards established by SIPs can be more restrictive than the federal guidelines outlined in CAAA, but not less restrictive. Instances do exist where states have implemented more restrictive ambient air quality standards.

Two elements that a SIP must contain are federal New Source Performance Standards (NSPS) and New Source Review (NSR) rules. The NSPS set maximum emission rates of pollutants for various processes, including combustion equipment. NSR rules govern the permitting of new emission sources. NSR rules are triggered if a new source is designated "major." A major source will emit or has the potential to emit pollutants at an annual rate greater than a level specified by the NSPS.

NSR rules distinguish between attainment areas (areas that currently meet the NAAQS) and nonattainment areas. There are two separate sets of rules for attainment and nonattainment areas. For 
attainment areas, Prevention of Significant Deterioration (PSD) rules apply. These rules are less stringent than if the area is designated nonattainment. If a new source is major and is located in a nonattainment area, then nonattainment NSR rules apply. In both instances, permitting a major new source requires that an air quality analysis be performed to determine if the facility will cause a deterioration in air quality.

In nonattainment areas, nonattainment emissions from a major new source are required to be "offset" at a ratio greater than one. This provision is the most important of the NSR nonattainment rules and is designed to decrease total air basin emission. For example, if a new source will emit 500 tons of $\mathrm{NO}_{\mathrm{x}}$ per year, the operator will have to obtain more than 500 tons/year worth of $\mathrm{NO}_{\mathrm{x}}$ offsets from within the air basin before a permit to operate will be issued. Offsets are created by reducing the emissions from other sources within the air basin by either installing air pollution control equipment or decommissioning of an existing source.

The CAAA NSR trigger rate for a simple-cycle combustion turbine (CT) is 100 tons/year of a nonattainment pollutant. ${ }^{1}$ Under federal rules, if a simple-cycle CT has the potential to emit more than 100 tons of the nonattainment pollutant it is subject to and must satisfy NSR rules. ${ }^{2}$ The trigger for NSR PSD rules in an attainment area is 250 tons/year for any regulated pollutant. It is possible but unlikely that a small (5 MW or less) simple-cycle CT would surpass these limits. However, additional state regulations may exist. The California NSR trigger in a "moderate" nonattainment area is 25 tons/year or $25 \mathrm{lbs} /$ day of any nonattainment pollutant or its precursor (CARB 1993). In "serious" and "extreme" nonattainment areas, the NSR trigger rates are 10 tons/year or $10 \mathrm{lbs} /$ day. A small simple-cycle gas turbine (for example, see page A5 in the Appendix) could exceed this limit and be subject to NSR rules.

National Environmental Policy Act The National Environmental Policy Act (NEPA) of 1969 requires the federal government to consider at all stages of decision making those factors that can affect the human environment (Argonne National Laboratory 1990). NEPA provides a framework to aid public officials when considering environmental factors and decisions that benefit the environment. Any "significant" project first requires an Environmental Assessment (EA). If it is found that the federal action would have a significant environmental impact, a detailed environmental analysis and an Environmental Impact Statement (EIS) are required. The relevance of NEPA to DU technologies is that it can influence the decision to install a DU facility, should an office of the federal government decide to require one of the above-mentioned actions. It would also govern a federal office's decision to provide research funding and, when federal regulation is involved, grant permission to businesses or state and local governments. More importantly, many states and local governments, stimulated by the federal government, have passed their own legislation establishing NEPA-like decision processes.

Other Federal Regulations There are other federal laws (Argonne, 1990) that could affect a DU project. They include, but are not limited to, the Clean Water Act (1987); the Resource, Conservation and Recovery Act (1976); the Occupational Safety and Health Act (1970); the Toxic Substances Control Act (1976); the Endangered Species Act (1973); the Coastal Zone Management Act (1972); and the Historic

${ }^{1}$ Federally monitored non-toxic air pollutants are ozone $\left(\mathrm{O}_{3}\right)$, carbon monoxide $(\mathrm{CO})$, particulate matter $(\mathrm{PM})$, sulfur oxides $\left(\mathrm{SO}_{\mathrm{x}}\right)$, nitrogen oxides $\left(\mathrm{NO}_{\mathrm{x}}\right)$, volatile organic compounds $(\mathrm{VOC})$, and lead $(\mathrm{Pb})$.

${ }^{2}$ Many air basins in the United States have been designated nonattainment for ozone (the ambient concentrations of ozone exceed the NAAQS). Ozone is not produced directly by combustion processes, but is a by-product of atmospheric photochemical reactions involving the precursors $\mathrm{NO}_{\mathrm{x}}, \mathrm{VOC}$, and, to a lesser extent, $\mathrm{CO}$. If a process emits ozone precursors, it will be regulated as nonattainment for these emissions even though the precursors themselves are not in violation of the NAAQS. 
Sites Act. It should be noted that both construction and operational aspects of DU projects could be affected by these laws.

\subsubsection{State Environmental Regulations}

Environmental regulations enacted by individual states either address state implementation of federal laws or create a distinct set of state regulations to satisfy unique needs within the state.

Air Quality Each state is responsible for implementing regulations that will satisfy the federal CAAA. Some states have implemented the federally recommended standards. Others have imposed more limiting regulations in response to severe air quality problems. In either case, the states have enacted laws instructing air pollution control officers at the local level to enforce federally enacted air quality regulations.

Environmental Considerations in Government Decisions Nineteen states have enacted laws creating regulations similar to NEPA (Corbus 1994). As with regulations at the federal level, state environmental policy acts provide guidelines to state agencies for incorporating environmental factors into the decision process. These guidelines determine the factors that will trigger an EA or EIS, and how the studies are conducted. If a DU project in one of the 19 states were to require a state permit, issuance of the permit would be contingent on an EA or EIS, as well as the other factors normally involved.

\subsubsection{Local Environmental Regulations}

Small generation units (typically less than $25 \mathrm{MW}$ ) are unlikely to trigger direct review by federal (CAAA Title IV) or state governments (state energy or public utility commissions). Local government, then, will have the largest environmental regulatory authority over DU generation projects. If a project is located within a city's limits, local government authorities will consist of both county and city offices. If located outside an incorporated area, county agencies maintain responsibility. It is important to remember that unless the city or county has passed a more restrictive ordinance, local agencies are enforcing state and federal statutes.

Air Quality Management Districts Air quality regulations enforced at the local level will have the largest regulatory impact on DU technologies employing fossil fuel combustion. In a district enforcing federal limits, a proposed unit will be subject to review if it has the potential to emit 100 tons/year of pollutants. An uncontrolled 20-MW simple-cycle gas turbine operating 2000 hours per year could surpass this value and be subject to regulation as a "major source."

The most restrictive air pollutant regulations in the country exist in southern California. The South Coast Air Quality Management District (SCAQMD) has regulatory authority over air pollution sources in the Los Angeles, California, metropolitan area. On January 1, 1994, SCAQMD Regulation XX, the Regional Clean Air Incentives Market (RECLAIM), went into effect. RECLAIM has created a $\mathrm{NO}_{x}$ and $\mathrm{SO}_{\mathrm{x}}$ allowance market in southern California. Any proposed new or modified major pollution source must employ emission control technologies and obtain emission allowances in order to obtain a permit to operate. Electric utility emission sources are subject only to the $\mathrm{NO}_{\mathrm{x}}$ program because the federal government has already regulated utility $\mathrm{SO}_{x}$ emissions through Title IV of the CAAA. The definition of an electric utility major source under the RECLAIM regulation is 4 tons/year of $\mathrm{NO}_{\mathrm{x}}$. A 3.5-MW simple-cycle gas turbine operating 2000 hours/year with $\mathrm{NO}_{x}$ control equipment has the potential to emit 4 tons of $\mathrm{NO}_{x}$ per year. The emission allowance program of RECLAIM is designed to address the air quality of the entire basin. In the more traditional sense of air quality regulation, RECLAIM also regulates point emissions. Proposed equipment is screened by its $\mathrm{NO}_{\mathbf{x}}$ emission rate. If the rate is large 
enough, an air quality analysis must be performed to determine if the new equipment will cause the local air quality to deteriorate to unacceptable levels.

Environmental Considenations in Local Government Governments at the city and county level may pass NEPA-like regulations. This possibility is more likely in large metropolitan areas where there is a concentrated demand for resources. It is also likely that a city or county will adopt the state or federal regulations for local implementation rather than expend the resources to develop their own.

Planning Commissions Obtaining a use permit from the city or county planning commission is an important step in the permitting process. The planning commission will determine if the proposed use of a site is appropriate. Factors that will influence the decision to permit include the current zoning status, planned uses for the surrounding area, effects on vehicle traffic, and any improvements that the site would require. The public has the opportunity to voice its opinion during the planning commission's deliberations. If the local government has a NEPA-like process, it is likely that the planning department will be the lead agency in its implementation.

Other Permit Requirements Typically, there are several other local agencies with which a project must file and obtain permits. These agencies will probably include, but are not limited to, the local water quality board, the city and/or county health department, and the city or county building department. The building department typically is responsible for water, sewage, street, building, and occupancy permits.

\subsubsection{Additional Siting Constraints}

A proposed DU facility must go through an increasingly difficult siting process. The mechanics of these processes vary according to the size, type, and characteristics of a proposed DU facility. The process allows the public, at some point, to influence the situation. It has become evident in recent years that the public is much more hostile to the siting of energy facilities. The public may agree that a given technology is needed and a good idea, yet it may not want the facility located nearby. This has given rise to the "Not In My Back Yard (NIMBY)" syndrome.

The reasons for this behavior vary and tend to be project-specific. It has been suggested that the underlying reason for public resistance to utility projects may be the erosion of confidence in public organizations and institutions (DOE 1993). Whatever the reasons, it is not unreasonable to expect that DU technologies may encounter disproportionate public resistance, since a large percentage of the transmission and distribution (T\&D) infrastructure to which DU may be applied is located in heavily populated areas.

\subsection{Brief Environmental Analysis of Selected DU Technologies}

After an electric utility's T\&D system has been screened for locations where DU technologies would have high value, an appropriate technology can be applied to the location. Among the differentiating factors, environmental characteristics and the regulations that apply to them are important and may have a strong impact on the decision to install a facility.

Eleven representative DU technologies were selected to examine the impact that their environmental characteristics may have on the siting process. The technologies are commercial or near-commercial. Tables A1-A11 in Appendix A are DU technology environmental forms constructed to summarize each technology's major environmental characteristics. A basic description of the technology is given, followed by a summary of physical characteristics, fuel and chemical requirements, and emissions characteristics. At the bottom of each environmental form is a table of the environmental regulations 
previously discussed that are most likely to have an impact on the siting process for each technology. The column on the right side of this table is used to indicate whether the regulatory authority or siting issue is likely to affect the given technology. Table 4-1 summarizes these regulatory and siting issue impacts for 11 technologies. The sole siting issue in the table is NIMBY, which, as described above, is really a catch-all for any number of specific problems that can create opposition to a project. All of the technologies have the potential to be affected by this phenomena (as indicated by the check boxes on the environmental forms on pages A1-A11 in the Appendix).

Table 4-1. Summary of Regulatory Impacts on 11 Selected DU Technologies

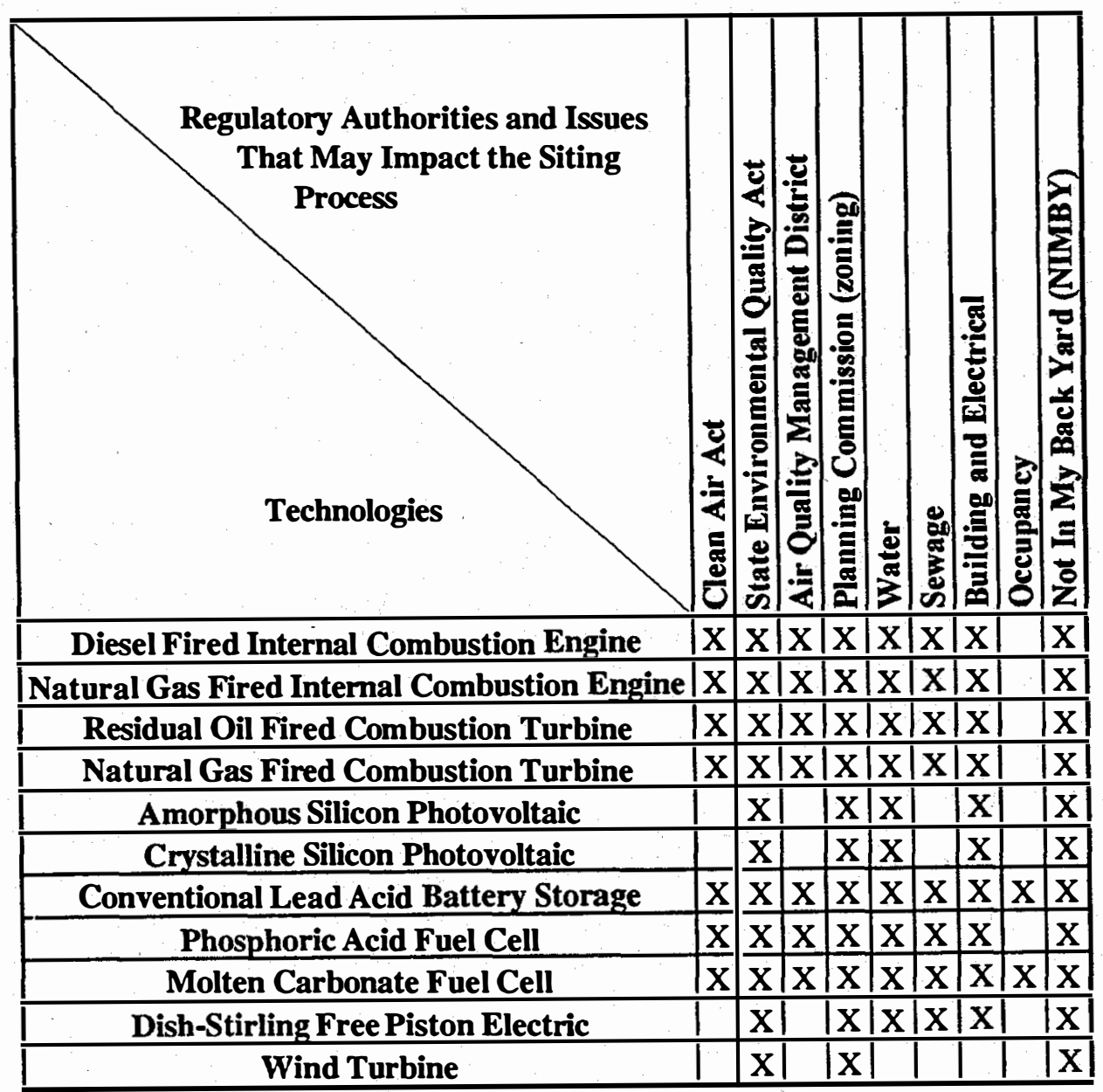

A technology's environmental characteristics can be grouped into two categories: physical characteristics and emissions characteristics. The physical characteristics of a technology are those that the technology possesses at all times, such as facility location, size, etc. Emissions characteristics are those that exist only when the facility is operating. Under federal, state, and local regulations, a proposed project will be analyzed based upon these two categories of attributes. Generally, local regulations first address physical characteristics. A proposed facility must be appropriate for a site's existing zoning and surrounding zoning. It must meet all aesthetic, structural, and occupancy requirements. Secondly, state and local regulations will examine the emission properties of a facility to determine if they can be properly managed so that the environment will not be adversely affected. 


\subsubsection{Physical Characteristics}

The tables on pages A1-A11 list for each technology the land areas required, the structural area and heights, and whether lighting and fencing are present. It was assumed that all of the technologies would require security lighting and fencing. Plant lighting is required only if the technology is housed within a building requiring illumination for human access. Facilities requiring human occupancy will generally require an occupancy permit. Only the battery storage and molten carbonate fuel cell projects described in the tables on pages A7 and A9 currently have this requirement. Future battery storage and molten carbonate fuel cell technologies may be stand-alone units that would not have such requirements.

To differentiate between the DU technologies presented, Table 4-2 lists their energy densities. Energy densities are calculated from the estimated area required for the DU facility, not the structural footprint of the actual equipment. ${ }^{3}$ The energy densities can be used as a first-order proxy for a technology's physical characteristics and as an indicator for the ease with which a technology can expect to obtain necessary approvals. Existing zoning and level of development are two influential parameters in the regulatory equation.

Table 4-2. Energy Densities of DU Technologies

\begin{tabular}{|c|r|}
\hline DU Technology & $\begin{array}{c}\text { Energy Density } \\
\left(\mathrm{kW} / \mathrm{m}^{\wedge} 2\right)\end{array}$ \\
\hline Wind Turbine & 0.01 \\
\hline Amorphous Silicon Photovoltaic & 0.02 \\
\hline Crystaline Silicon Photovoltaic & 0.02 \\
\hline Dish-Stirling Free Piston Electric & 0.04 \\
\hline Phosphoric Acid Fuel Cell & 1.0 \\
\hline Conventional Lead Acid Battery Storage & 1.6 \\
\hline Molten Carbonate Fuel Cell & 3.3 \\
\hline Natural Gas Fired Internal Combustion Engine & 48.9 \\
\hline Diesel Fired Internal Combustion Engine & 51.4 \\
\hline Residual Oil Fired Combustion Turbine & 58.7 \\
\hline Natural Gas Fired Combustion Turbine & 58.7 \\
\hline
\end{tabular}

${ }^{3}$ The energy density figure for wind turbines is based on the land requirement for a windfarm with normal wind turbine spacings (ten rotor-diameter distance between rows of wind turbines and five rotor-diameter distance between adjacent wind turbines). 


\subsubsection{Emissions}

Of the different air, liquid, and solid emissions that may be associated with the DU technologies, air emissions have the strongest influence on a project's viability because of their impact on the siting process. The tables on pages A1-A11 list the uncontrolled emission rates for the $11 \mathrm{DU}$ technologies presented in this analysis. Table 4-3 lists the technologies in ascending order by their $\mathrm{NO}_{\mathbf{x}}$ emission rates. Again, the $\mathrm{NO}_{x}$ emission rates are a first-order proxy for emission characteristics. The actual consequences air emissions will have for a given technology are specific to the location of the proposed facility.

Table 4-3. $\mathrm{NO}_{\mathrm{x}}$ Emission Rates for 11 DU Technologies

\begin{tabular}{|c|c|c|c|c|}
\hline DU Technology & $\begin{array}{c}\text { Uncontrolled } \\
\text { NOx Emission } \\
\text { Rate } \\
(\mathbf{b} / \mathbf{m m B t u}) \\
\end{array}$ & $\begin{array}{l}\text { NOx Emission } \\
\text { Rate }(\mathrm{lb} / \mathrm{kWh})\end{array}$ & \begin{tabular}{|c|} 
Annual \\
Emissions for a \\
1 MW Plant @ \\
$10 \%$ CF (tons) \\
\end{tabular} & $\begin{array}{l}\text { Annual Emissions for } \\
\text { a } 1 \text { MW Plant @ 10\% } \\
\text { CF and } 80 \% \text { Effective } \\
\text { NOx Control (tons) }\end{array}$ \\
\hline Amorphous Silicon Photovoltaic & 0.0 & 0.0 & $\begin{array}{r}0.0 \\
\end{array}$ & 0.0 \\
\hline Crvstaline Silicon Photovoltaic & 0.01 & 0.0 & 0.0 & 0.0 \\
\hline Conventional Lead Acid Battery Storage & 0.01 & 0.0 & 0.0 & 0.0 \\
\hline Dish-Stirling Free Piston Electric & 0.0 & 0.0 & $\mathbf{0 . 0}$ & 0.0 \\
\hline Wind Turbine & 0.0 & 0.0 & 0.0 & 0.0 \\
\hline Molten Carbonate Fuel Cell & 0.003 & 0.000018 & 0.008 & 0.002 \\
\hline Phosphoric Acid Fuel Cell & 0.02 & 0.000171 & 0.075 & 0.015 \\
\hline Natural Gas Fired Combustion Turbine & 0.4 & 0.0058 & 2.523 & 0.505 \\
\hline Diesel Fired Combustion Turbine & 0.6 & 0.0088 & 3.847 & 0.769 \\
\hline Diesel Fired Internal Combustion Engine & 2.8 & 0.025 & 11.018 & 2.204 \\
\hline Natural Gas Fired Internal Combustion Engine & 3.1 & 0.029 & 12.899 & 2.580 \\
\hline
\end{tabular}

In Table 4-3, only the technologies that convert fossil fuels to electricity possess $\mathrm{NO}_{\mathrm{x}}$ emissions. The impact of these emission rates on the regulatory process can be illustrated by applying the strictest regulations in the United States, which are enforced in Los Angeles. Under the RECLAIM program recently enacted by SCAQMD, only the internal combustion (IC) and CT technologies listed in Table 4-3 would be subject to review. SCAQMD has exempted the ONSI phosphoric acid fuel cell (which is commercial) from requiring an air permit because of its low emissions. SCAQMD will very likely pass similar regulations for the molten carbonate technology. If an 80 percent effective control technology were assumed to be applied to the uncontrolled $\mathrm{NO}_{x}$ emission rates for the IC and CT technologies in Table 4-3 (capacities are normalized to $1 \mathrm{MW}$ ), only the IC technologies would have a high enough emission rate to require air analysis modeling. However, all four technologies would have to participate in the RECLAIM program based on their potential to emit (all four would exceed 4 tons of $\mathrm{NO}_{x}$ per year at high-capacity factors). If the facilities were to guarantee operation of only 876 hours/year, then all four technologies would be exempt from the RECLAIM program.

However, exemption from the RECLAIM program may not be desirable. A CT or IC technology would still be subject to NSR rules under other SCAQMD regulations. The applicable regulations stipulate the use of Best Available Control Technology, air analysis screening, and possibly modeling for both criteria pollutants and toxic emissions. Offsets are required. Obtaining offsets outside of the RECLAIM program may be more difficult because there is no market established to make them available. A proposed new source would have to create its own offsets by reducing emissions from another source within the basin 
at a ratio greater than one. In most cases, however, a new source that is exempt from RECLAIM may chose to participate.

\subsubsection{Summary}

This section summarized the major environmental characteristics of $11 \mathrm{DU}$ technologies (see pages A1-A11). The technology energy densities and $\mathrm{NO}_{x}$ emission rates were developed and used as a firstorder representation of the technology's physical and emissions characteristics (Tables 4-2 and 4-3). Certainly these relationships are a generalization and are not exact. But as a first-order illustration of trends, Tables 4-2 and 4-3 are useful. They summarize attributes that can be both positive and constraining.

It is clear from Table 4-2 that the four combustion technologies described are very compact. This property alone would probably allow these technologies to be evaluated as candidates for additional locations. However, the higher energy densities equate to a higher intensity of use. These technologies operate at high temperatures and have more concentrated noise and air emissions. Generally, these technologies would be more likely to gain regulatory approval on their physical characteristics, but less likely to gain approval based on their emission characteristics.

Fuel cell and battery storage technologies require more land area than combustion technologies. Area requirements, however, are not excessive. The ONSI PC25 $200-\mathrm{kW}$ fuel cell has a structural footprint of only $84 \mathrm{~m}^{2}\left(900 \mathrm{ft}^{2}\right)$. As shown in Table 4-3, fuel cells have very low emissions. Flooded battery. technologies (like those used at the facility described on page A7 in the Appendix) have virtually no air emissions. Possessing a combination of these properties (reasonably compact, ultra-low emissions) is very desirable because from a regulatory viewpoint these technologies are more likely to gain approval on both accounts. This fact may help contribute to widespread use of these technologies for distributed applications.

Due to the diffuse nature of their energy source, solar technologies require large areas to produce the same amount of energy compared to a fossil fuel powered technology. Because of this environmental property, the number of practical sites where this technology can be applied may be reduced. Solar technologies have the advantage, however, of creating no emissions. Therefore, solar technologies are less likely to gain approval on their physical attributes and more likely to be valued based on their zero emissions. Also, PV technologies can be integrated architecturally into structures, providing a niche for the technology that does not require large parcels of land for small-scale dispersed generation. Emissionfree and nonobtrusive PV may be an ideal technology for DSM end-use power generation.

Wind technology is relatively environmentally benign. Like PV and solar thermal technologies, wind energy production does not generate air emissions or waste, but requires relatively large areas in order to maximize energy production. ${ }^{4}$ Some wind turbines of old design may cause objectionable noise, but the current generation of wind turbines are much improved. A more significant environmental concern to date with wind turbine operation in certain areas appears to be wildlife habitat impact, especially collisions involving raptors. Extensive research is under way to determine the nature and extent of the problem. It is not clear how this problem will affect future wind turbine installations.

\footnotetext{
${ }^{4}$ The spacing of wind turbines is determined by local terrain and the effects of wind turbine wake interference. Typical wind turbine spacing in California is two to three turbine diameters between adjacent turbines and ten turbine diameters between rows.
} 
It is important to point out that the DSM options discussed in Section 2 do not have the siting constraints that are discussed here. DSM technologies, such as energy-efficient devices and direct load control, do not have a large regulatory infrastructure overseeing their installation and use, as do power generation technologies. After a DSM technology has been approved for use (i.e., accepted by building and electrical codes) it will encounter few siting constraints.

The environmental analysis presented here considers only the operational emissions characteristics of selected technologies. The analysis is consistent with current siting requirements. The reader should be aware that additional emissions will occur during the manufacturing and decommissioning of a facility and during the mining and transportation of fuel, where this is applicable. Emissions that occur at these other phases of construction or stages of the fuel cycle can be addressed with a full fuel cycle methodology.

\subsection{Siting Examples}

Six siting examples were obtained from the literature and through personal communication to illustrate the siting process.

\subsubsection{The Chino Battery Energy Storage Plant}

The Chino Battery Energy Storage Plant, procured and operated by the Southern California Edison Company (SCE), is a 10-MW, 4-hour storage plant (United Engineers \& Constructors, Inc. 1992). The facility consists of three buildings on a 1.25-acre site at SCE's Chino substation in the City of Chino, California. It was constructed between October 1987 and March 1988 and began operations in July 1988, at a cost of $\$ 13.5$ million. It is located in an urban area.

Because battery storage technologies are relatively small and pose no substantial aesthetic concerns, it was believed that there would be no major barriers to the siting process. These initial beliefs were correct. The siting process proceeded as expected and the Chino facility received all necessary permits. The entire permitting process took 14 months and required ten permits.

At the state level, review was required by the California Energy Commission to determine if the facility met state energy efficiency standards. This routine review was completed without incident.

Two permits were required at the regional level. Regional offices in California are typically comprised of and funded by counties that reside in the same watershed (water board) or air basin (air quality management district). Facility plans were required to be filed with the regional Water Quality Control Board and the SCAQMD. The water board determined that battery acid spill contingencies were adequate and no permit was required for the facility. SCAQMD granted a permit to construct, which also served as a temporary permit to operate after approving the plan for mitigating emissions of hydrogen, arsine, and stibine from the batteries.

One permit was required from a county office, the County Department of Environmental Health Services. The department contacted SCAQMD, found that the planned methods of arsine and stibine control were adequate, and approved the planned mitigation method. The department approved the facility with the recommendation that the concrete acid-containment structure be epoxy sealed so that, in the event of a spill, the concrete would not adsorb the acid and become hazardous waste.

Seven permits were required from the city of Chino. The most important city permit was a Conditional Use Permit (CUP). The city planning commission reviewed the plans for the facility to determine if the 
planned use of the site was in accordance with city plans. The planning commission issued the CUP after requiring SCE to accept responsibility for improvements to the streets adjacent to the facility. The respective city offices issued permits for water and sewage connections and road grading. The building department issued a building permit after the CUP was issued. The City of Chino Health Department issued its required permit after determining that a wastewater discharge permit would not be required. Finally, an Occupancy Permit was issued after all the safety systems were demonstrated to be operational.

\subsubsection{Sacramento Municipal Utility District Distributed Generation ONSI Fue/ Cell}

The Sacramento Municipal Utility District (SMUD), located in Sacramento, California, began operating a 200-kW ONSI fuel cell power plant within its service district at a Kaiser Hospital in early 1994. A brief description of this facility's siting process was obtained from SMUD's General Planning Department (Hansley 1994). Standard city permits were obtained without encountering any difficulties.

In addition to the city permits, review and permitting was required by the Sacramento Air Pollution Control District (SAPCD) and the California State Office of Health and Planning (CSOHP). SAPCD reviewed the SMUD fuel cell application and decided to require an air permit. SMUD reflected that the primary reason for requiring the permit was the lack of experience with the technology. SMUD also stated that SAPCD may in the future exempt the ONSI fuel cell (and other fuel cell technologies) once an operating history of ultra-low emissions has been established.

CSOHP has planning authority over hospitals in the state of California. SMUD was required to obtain a building permit through CSOHP. CSOHP is a state agency and therefore must implement the California Environmental Quality Act (CEQA) in its decision process. As part of the permitting process, an EA, complete with public hearings, was performed. The EA found that no adverse environmental consequences would occur, and a permit was issued.

\subsubsection{South Coast Air Quality Management District ONSI Fuel Cell}

The SCAQMD has installed a 200-kW ONSI fuel cell power plant to provide electrical power and highgrade thermal heat to SCAQMD office buildings in a demonstration project. Because of its ultra-low emissions, SCAQMD has exempted the ONSI fuel cell power plant from requiring an air permit within the South Coast air basin.

\subsubsection{PG\&E Company 500-kW Photovoltaic Distributed Generation Plant}

In April 1993, after six months of construction, a 500-kW photovoltaic plant went into operation at the PG\&E Kerman substation near Fresno, California. The 500-kW plant employs Siemens Solar crystalline silicon PV technology, passive one-axis horizontal tracking, and occupies 5 acres. A brief accounting of the siting issues involved with the facility was obtained from Daniel Shugar, who was the PG\&E project manager (Shugar 1994).

Mr. Shugar commented that all standard permits were obtained without incident. The only difficulties encountered were associated with obtaining a 5-acre parcel for the facility. The land surrounding the city of Kerman is zoned agricultural and is divided into large lots measuring several hundred acres each. In order to site the facility, PG\&E had to petition the county planning commission to divide a lot (creating a 5-acre parcel) and allow nonagricultural use. In the Central Valley of California, one of the prime agricultural production areas of the world, there is strong opposition to rezoning land for uses other than agricultural. PG\&E's petition met with strong opposition from local farmers concerned that the PV facility could lead to additional lot divisions, additional rezoning, and a speculative rise in land values 
causing subsequent increases in property taxes. Mr. Shugar also commented that there appeared to be general hostility and mistrust directed toward PG\&E simply because it was a large corporation.

In the end, PG\&E was successful, but paid a large sum for the 5-acre parcel. Mr. Shugar also noted that PG\&E was not able to inject the power from the facility directly into the distribution system at the most beneficial point because adequate land was not available there. However, they did come very close. It is also important to note that an air permit was not required, as would be the case for any photovoltaic facility.

\subsubsection{Santa Clara Demonstration Group 2-MW Molten Carbonate Fuel Cell}

The Santa Clara Demonsuration Group (SCDG) recently broke ground to construct a 2-MW molten carbonate fuel cell demonstration plant. The facility will be connected to the City of Santa Clara's electrical distribution system. Santa Clara is a member of SCDG, as is the Electric Power Research Institute (EPRI). In 1991, EPRI published a report (Resource Management International 1991) documenting the anticipated siting requirements for this project. The report attempts to list all of the relevant agencies from which permits must be obtained.

Permits would be required for toxic water discharges from the plant. If the toxicity of the discharge is not significant, then no permit would be required. If the toxicity level is above typical residential concentrations, the facility can obtain a permit from the City of Santa Clara's Water Pollution Control Plant and discharge to the plant. The other alternative is to obtain a permit from the San Francisco Bay Area Regional Water Quality Board and discharge directly into state surface waters.

Standard city permits would include zoning, building, electrical, water, sewer, and storage of hazardous materials, all of which are administered by various city departments. The City of Santa Clara also has an Architectural Review Board that would have to certify the facility as aesthetically compatible with surrounding land uses. If the project is approved by all of the relevant city offices, the Planning Division of the Planning and Inspection Department would issue a CUP. The report also states that the city planning department is the lead agency for the implementation of the CEQA. Therefore, during the review process, the planning department would perform an initial analysis to determine if an EA or EIS is required and then act accordingly.

The Santa Clara County Health Department regulates hazardous wastes in both the county and incorporated areas within the county. The facility, if a generator of toxic wastes, would require a permit from this department. The permit would stipulate methods of storage, personnel training requirements, and other operational considerations.

The Bay Area Air Quality Management District (BAAQMD) regulates criteria and toxic air emissions from facilities in its territory. BAAQMD regulations do not allow new emission sources that cause a net increase in a nonattainment pollutant or a precursor. However, the MCFC emissions are so low that the report anticipated BAAQMD would exempt the demonstration facility from requiring an air permit. Future BAAQMD regulations regarding commercial fuel cells, though, are uncertain. If the fuel cell facility were to have any toxic emissions, they would require mitigation measures and permitting.

\subsubsection{EPRI/PG\&E Collaborative DU Internal Combustion Generator Set}

At the beginning of the second quarter of 1994, PG\&E began operating a 1000-kW Caterpillar generator set fueled with natural gas. The generator set is located at PG\&E's Ignacio substation near the San Francisco Bay area and is a joint research project between PG\&E and EPRI. The generator set is 
contained in a 40-foot trailer that provides mobility if necessary. This generator set, however, will remain at the Ignacio substation for the duration of the study. The project is designed to help determine the economic and technical benefits of natural gas-fueled internal combustion DU technology.

Jonne Berning, the EPRI project manager for this study, explained that the facility's remote location resulted in the requirement of only two permits for the system (Berning 1994). The first permit was a city use permit issued by an inspector that examined the low voltage electrical connections to the trailer. The high voltage connections from the generator to the utility distribution system are PG\&E's responsibility.

The second required permit was the air permit. Mr. Berning noted that he contacted the Air Quality Management District (AQMD) very early during the project design so the air permitting process could be fully understood and worked into project plans. He applied for and received a Research and Development permit. The permit allows the generator set to operate for 1500 hours during the first year of operation. The current configuration of the Caterpillar generator set has an emission rate of $1.5 \mathrm{~g} / \mathrm{hp}-$ hr of $\mathrm{NO}_{\mathrm{x}}$. The R\&D permit can be renewed beyond the first year as long as PG\&E refits the Caterpillar engine with an improved ignition system that will bring the emission rate down to $1 \mathrm{~g} / \mathrm{hp}-\mathrm{hr}$ of $\mathrm{NO}_{\mathrm{x}}$. $\mathrm{Mr}$. Berming noted that obtaining the R\&D permit allowed the project to go forward without having to apply costly air pollution control equipment to the generator set. The current emission standard in the bay area AQMD is $0.3 \mathrm{~g} / \mathrm{hp}-\mathrm{hr}$ of $\mathrm{NO}_{\mathrm{x}}$. He also noted that if use of the technology were to become standard practice, additional emission control equipment would have to be applied to the generator set in order to meet the bay area AQMD emissions standard.

\subsubsection{Summary}

In Section 4.2 we stated that a DU technology's physical and emissions characteristics to a large extent are evaluated individually by regulatory authorities. Furthermore, Section 4.2 proposed that these two classes of characteristics can be represented by the technology's energy density and $\mathrm{NO}_{x}$ emission rate and that these two parameters are a first-order indication of the ease with which a facility wins regulatory approval. Technologies with a relatively low energy density or a relatively high emission rate encounter more difficulty.

The six siting examples presented here appear to support this conclusion. PG\&E's engine/generator set project helps demonstrate the regulatory difficulty that can be encountered by technologies with high emission rates. The internal combustion generator set deployed by PG\&E at the Ignacio substation encountered regulatory scrutiny because of its emissions. If not for the issuance of an R\&D air permit, costly air pollution control equipment would have had to be installed and, most likely, emission offsets obtained. The Kerman PV facility met with resistance due to the relatively large land area required for its operation. Public opposition to the project stemmed primarily from the proposed nontraditional use of the land in the area.

The remaining four siting examples presented (three fuel cells and the Chino battery storage facility) employed technologies that were characterized as having relatively moderate energy densities and ultralow (and therefore favorable) emissions characteristics. The Chino battery storage plant, while required to undergo a thorough permitting process, obtained approval without difficulty. The facility was relatively compact, easy to locate at an existing substation, and did not require an air permit for criteria pollutants. The project demonstrated that battery storage technologies can be deployed in urban areas without undue regulatory barriers. The three fuel cell projects had a similar result. 


\subsection{Conclusions}

This section summarized the major environmental characteristics of the selected DU generating and storage technologies and the environmental regulations that affect their use. Actual siting experiences of several DU technologies were described. Although the examples are limited, they do provide valuable insight as to how different distributed technologies will fare in the siting and permitting processes. It is evident that local regulations are an important consideration for DU applications. The close proximity of DU technologies to load precipitates that DU facilities will confront more intense scrutiny over land use, air quality, or other specific local concerns.

As expected, technologies with a medium energy density but extra-low emissions have had few siting problems in populated areas, even where very restrictive environmental regulations exist. Actual siting examples indicated that PV, fuel cells, and battery storage facilities could expect to enjoy a reduced regulatory burden in obtaining necessary permits. Technologies with a high energy density but relatively high emission rates, such as a gas turbine or internal combustion engine/generator sets, may face serious siting and operational restrictions. The Kerman PV project, like other renewable technologies with no emissions, did not require an emissions permit. However, the Kerman PV project does suggest that land acquisition is a potential barrier for using PV technology in DU applications in some areas. Other implementation strategies (for example, rooftop PV installations) may be necessary to ease the constraint of a large land area requirement.

The analyses and actual siting examples presented in this section indicate that environmental regulations and siting restrictions are technology-specific. Generating technologies used in DU applications face the same environmental regulations and rules as those for central station applications. If the installations are close to existing residential and commercial loads, additional restrictions imposed by local authorities may exist. This situation suggests that the environmental burden for DU facilities may be proportionally higher because of their smaller size and capital expenditure, compared to conventional central station installations. 


\subsection{Planning and Operating Considerations}

The DU concept represents a substantial departure from conventional utility practice. The distribution network of utilities is built to take power from a high-voltage transmission network, step it down to lower voltages, and deliver it to end users. This portion of the electric power system is closest to the utility customers, therefore, its performance and reliability directly affect the quality of service that the customers receive. Although power lines in the distribution system appear to form a grid, the great majority of them actually operate in radial mode. Utilities install sectionalizing (normally closed) and tie (normally open) switches in the distribution system so that power generally flows in one direction. The system is not designed to accommodate local generation.

When an active power source is introduced into the distribution network, it may change the direction of power flow on a distribution feeder from its original design. Distribution feeder protection and voltage regulating devices are coordinated, assuming power only flows from substation to loads. Additional coordinating steps and equipment may be required and operating procedures may need to be modified. The overall impact of these factors on the power system will depend on the penetration level of the various DU technologies. At lower levels of penetration, when dispatch, protection, and safety are major issues, DU technologies affect only the local distribution system and its operations. When many DU technologies are installed in the distribution system, their interactions with generation and transmission system operations may cause stability and control concerns (DUV Project monograph 1993). As the penetration increases, the impact of DU implementation becomes system-wide, and new approaches to control, monitor, and dispatch the distributed resources may have to be developed to maximize the benefits of DU technologies.

The following four factors relating to DU technologies may have significant impacts on the planning and operation of electric utility systems.

(1) Valuation - Economic consideration provides critical justifications for installing DU technologies. Distribution system planners and engineers traditionally rely only on feeder reconfigurations, facility upgrades, and system additions to provide electric service to customers. Power production at the distribution level has not been an issue. By installing DU technologies, system planners and engineers gain additional tools and flexibility to meet customer demand. The modularity of DU technologies also affords utilities the opportunity to significantly reduce risk in planning. However, along with the increased benefits, implementing DU technologies may require additional costs for monitoring, control, and O\&M. Utilities need models and methodologies to determine the values of distributed benefits and to maximize these values through optimal implementation strategy. EPRI and other organizations are currently developing such models. Modeling and valuation methodologies are beyond the scope of this report; however, the technical characteristics and cost information included here are intended to be used by utility planners and engineers to investigate the applicability of DU technologies in specific utility environments.

(2) Operability - Operability of a DU technology refers to its ability to be started and then operated at a desired load level, and to respond properly to system emergency conditions. It also means that implementation of a particular technology must be compatible with the existing power system and should not impair its stability and performance. The DU technologies listed here have all been tested or operated in utility systems. Test results and operating experiences to date indicate that few small, dispersed generating systems can be interconnected and operated successfully in the electric utility distribution systems. Standards have been developed for the interface to ensure that adequate safety, protection, and service quality are maintained. At this level, the impacts of DU technologies 
on the utility system are small and limited to only a specific part of the system. However, when both the number and aggregated capacity of installed DU technologies increase, so may the problems for utilities.

Many DU technologies use electronic inverters to interface with the utility grid. The electronic inverter interface has different transient and short-circuit characteristics. Thorough analyses are needed to ensure that installation of DU technologies will not affect system operation and protection. For renewable energy DU technologies such as PV, wind, and solar thermal, a substantial portion of DU benefits depend on a close match between the power output and local peak load, and resource intermittency becomes an important issue. A clear understanding of the impact of DU technologies on system operations is necessary, and mitigation measures need to be researched.

(3) Reliability - When a DU technology is installed to defer a distribution upgrade, it is important that comparable service reliability is maintained. This is a critical issue for DU implementations because the concept of using active devices (generators and batteries) to substitute for passive ones (transformers and conductors) departs from traditional distribution system planning and design practices. On the other hand, DU technologies can also be used to enhance service reliability. Presently, not enough is known about DU reliability issues. Additional research is required to determine the adequate level of service reliability and the impact of DU technologies on service reliability.

(4) Control and dispatch - A large portion of DU benefits are derived from the ability of the technology to match supply with local load. DU technologies can also provide system capacity and energy values by generating power during system peak demand periods. To achieve these benefits, necessary control and dispatch strategies must be developed. The objectives of DU technology control and dispatch include coordinating the local generation, storage, and load control strategies with system generation control, maintaining a proper voltage profile, and minimizing operating costs. The presence of active generation and energy storage systems in the distribution network may require a more sophisticated control system and advanced telecommunication capabilities to handle the added control and dispatch functions. Further research is also needed to design optimal control and dispatch strategies and to develop cost-effective hardware to implement such strategies.

In addition, regulation and competition can also influence the planning processes of DU. Utilities are beginning to restructure themselves to become more responsive to changing market conditions. Competition and restructuring could result in a utility structure in which generation, transmission, and distribution are owned by different entities. Issues of who can own DU facilities and how DU benefits will be captured and distributed will have to be addressed.

This report did not address planning and operating issues that would affect the implementation of DU by utilities; even an in-depth discussion of some of these issues is beyond the scope of this report. Readers are advised to review the reference section of the report for more information. Many utilities and researchers are beginning to study these issues. Substantial research efforts are needed before they can be resolved. 


\subsection{References}

Akhil, A., et al. (August 1993). Specific Systems Studies of Battery Energy Storage for Electric Utilities. Sandia National Laboratories. SAND93-1754.

ANSI/IEEE (1988). IEEE Recommended Practice for Utility Interface of Residential and Intermediate Photovoltaic (PV) Systems. ANSI/IEEE Std 929-1988.

ANSI/IEEE (1988). Guide for Interfacing Dispersed Storage and Generation Facilities with Electric Utility Systems. ANSI/IEEE 1001-1988.

Atlantic Orient Corporation (1993). Product Specifications Sheets.

Bean, J.R. and Diver, R.B. (August 8-13, 1993). "Performance of the CPG 7.5-kW Dish-Stirling System," 28th Intersociety Energy Conversion Engineering Conference Proceedings. IECEC 1993. Atlanta, Georgia.

Berning, J. (April 1, 1994). Personal communication. Electric Power Research Institute, Palo Alto, California.

Brookhaven National Laboratory (1987). Analysis and Technology Transfer Annual Report - 1986.

California Air Resources Board (March 1993). The California Clean Air Act and Closely Related Statutes. Sacramento, California: California Air Resources Board, pp.17-20.

California Energy Commission (December 1992). 1992 Energy Technology Status Report, Appendix A Volume II: Detailed Electric Generation Technology Evaluations. Staff Report.

California Energy Commission (March 1990). Advanced Lighting Guidelines. Handbook.

California Energy Commission (June 1993). Wind Project Performance: 1992 Summary. Commission Report.

Cavallo, A.J., Hock, S.M., and Smith, D.R. (1993). "Wind Energy: Technology and Economics." in Renewable Energy: Sources for Fuels and Electricity. Johansson, T. et al. eds. Island Press, Washington, D.C.

Cohen J. (1993). "Advanced Horizontal Axis Wind Turbines in Windfarms," Technology Characterization, draft report. Office of Planning and Assessment, U.S. Department of Energy.

Cook, G.M., Spindler, W.C., and Grefe, G. (March 1991). "Overview of Battery Power Regulation and Storage," IEEE Transactions on Energy Conversion. Vol. 6, No. 1.

Corbus, D. (February 15, 1994). Personal communication. National Renewable Energy Laboratory, Golden, Colorado.

De Laquil, P. III, Kearney, D., Geyer M., and Diver, R. (1993). "Solar-Thermal Electric Technology." in Renewable Energy: Sources for Fuels and Electricity. Johansson, T. et al. eds., Island Press, Washington, D.C. 
Department of Energy (February 1994). Research and Development of Proton-Exchange-Membrane (PEM) Fuel Cell System for Transportation Applications Initial Conceptual Design Report. DOE/CH/ 10435-01. Office of Transportation Technologies, DOE.

Department of Energy (February 1994). Utility Battery Storage Systems Program Plan: FY1994-FY1998. DOE/CH10093-258.

Eckroad, S. and Radimer, B. (June 1991). "Review of Engineering Design Considerations for Battery Energy Management Systems," IEEE Transactions on Energy Conversion. Vol. 6, No. 2.

Edison Electric Institute (1993) Statistical Yearbook of the Electric Utility Industry/1992. EEI Washington, D.C.: Edison Electric Institute.

Electric Power Research Institute (September 1987). TAG Technical Assessment Guide Volume 2: Electricity End Use Part 1: Residential Electricity Use-1987. EPRI P-4463-SR, Volume 2, Part 1, Special Report.

Electric Power Research Institute (October 1988). TAG Technical Assessment Guide Volume 2: Electricity End Use Part' 2: Commercial Electricity Use-1988. EPRI P-4463-SR, Volume 2, Part 2, Special Report.

Electric Power Research Institute (1989). Supermarket Refrigeration Modeling and Field Demonstration. EPRI CU-6268.

Electric Power Research Institute (December 1989). Photovoltaic Operation and Maintenance Evaluation. EPRI GS-6625, Final Report.

Electric Power Research Institute (1990). Guide to the Selection of Supermarket Refrigeration Systems . EPRI CU-6740.

Electric Power Research Institute (1990). Supermarket Air Conditioning and Dehumidification. EPRI CU-3031.

Electric Power Research Institute (January 1990). Potential Economic Benefits of Battery Storage to Electric Transmission and Distribution Systems. GS-6687, Final Report.

Electric Power Research Institute (August 1990). DSM: Transmission and Distribution Impacts. EPRI CU-6924, Final Report.

Electric Power Research Institute (January 1991). Public Power's Fuel Cell Commercialization Initiative. EPRI GS-7099, Final Report.

Electric Power Research Institute (April 1991). End-Use Technical Assessment Guide (End-Use TAG ${ }^{\mathrm{m}}$ ) Vol. 4: Fundamentals and Methods. EPRI CU-7222.

Electric Power Research Institute (May 1991). Photovoltaic System Performance Assessment for 1989. EPRI GS-7286, Final Report.

Electric Power Research Institute (May 1992). Targeting DSM for Transmission and Distribution Benefits: A Case Study of PG\&E's Delta District. EPRI TR-100487. 
Electric Power Research Institute (May 1992). Molten Carbonate Fuel Cells as Distributed-Generation Resources- Case Studies for the Los Angeles Department of Water and Power. EPRI TR-100686, Final Report.

Electric Power Research Institute (June 1993). TAG Technical Assessment Guide Electricity Supply 1993. EPRI TR-102276-V1R7, Volume 1: Rev. 7.

Electric Power Research Institute, National Renewable Energy Laboratory, and Pacific Gas \& Electric Company (July 1993). Distributed Utility Valuation Project Monograph. EPRI TR-102807.

The Energy Daily (August 3, 1993). Vol. 21, Number 147.

Energy Research Corporation specification sheet, 1992.

L'Ecuyer, M. et al. (April 1993). Space Conditioning: The Next Frontier. Environmental Protection Agnecy, Office of Air and Radiation, EPA 430-R-93-004.

Gas Turbine World (1993). Gas Turbine World The 1993-94 Handbook. Vol. 15.

Green, M.A. (1993). "Crystalline- and Polycrystalline-Silicon Solar Cells." in Renewable Energy: Sources for Fuels and Electricity. Johansson, T. et al. eds. Island Press, Washington, D.C.

Green, M. and Emery, K. (July 1994). "Solar Cell Efficiency Tables," Progress in Photovltaics. Volume 2. p. 201.

Hensley, R.A. (March 2, 1994). Personal communication. Sacramento Metropolitan Utility District, Sacramento, California.

Hirsh, R. (1989). Technology and Transformation in the American Electric Utility Industry. New York: Cambridge University Press.

Hirshenhofer, J.H. (August 1993). "Fuel Cell Technology Status," 28th Intersociety Energy Conversion Engineering Conference Proceedings. Atlanta, Georgia. August 8-13, 1993.

Hislop, D. (1992). Energy Options. London: Intermediate Technology Publications.

Hubbard, H.H. and Shapherd, K.P. (June 1991). "Aeroacoustics of Large Wind Turbines," Journal of the Acoustical Society of America (89:6); pp. 2495-2508.

IEEE (1992) IEEE Recommended Practices and Requirements for Thyristor Converters and Electric Power Systems. IEEE 519-1992.

Lawrence Berkeley Laboratory (1989). Technology Assessment: Energy-Efficient Commercial Lighting. U.S. Department of Energy.

Lock, R., et al. (1991). The New Clean Air Act: Compliance and Opportunity. Arlington, Virginia, Public Utilities Reports, Inc., pp. 1-6; 241-283.

Lopez, C.W. and Stone, K.W. (1992). "Design and Performance of the Southern California Edison Stirling Dish," ASME International Solar Energy Conference, Maui, Hawaii, March 1992. 
Lewis, R. (March 7, 1994). Personal Communication. Solar Turbines.

Lynette, R. (March 1989). Assessment of Wind Power Station Performance and Reliability. EPRI GS6256. Electric Power Research Institute. Final Report.

Maycock, P.D. (1993). Photovoltaic Technology, Performance, Cost and Market Forecast, 1990-2010. Casanova: Photovoltaic Energy Systems, Inc.

New York State Energy Research and Development Authority (July 1991). Commercial Lighting Technology Assessment.

Proceedings of Battery Storage Applications Workshop. September 22-23 1992. Burlingame, CA. Electric Power Research Institute.

PV News. February 1994.

PV News. June 1994.

PV News. July 1994.

PVUSA Project Team. (April 1993). 1992 PVUSA Progress Report. Brian Farmer, Project Manager. Report Number 007.5-93-4.

Real Goods. (1991). Alternative Energy Sourcebook 1991. Real Goods Trading Corporation, Ukiah, California.

Resource Management International (June 1991). Two Megawatt Molten Carbonate Fuel Cell Power Plant: License and Permit Requirements. EPRI/GS-7418. Electric Power Research Institute. Work performed by Resource Management International, Inc., Sacramento, California, pp.1-23.

Sandler, H.S. and Farooque, M. (August 1993). "Cost and Performance of an Nth Generation 2 MW Carbonate Fuel Cell Power Plant Based on the Santa Clara Demonstration Project Design," 28th Intersociety Energy Conversion Engineering Conference Proceedings. Atlanta, Georgia. August 8-13, 1993.

Shugar, D.S. (February 17, 1994). Personal communication. Advanced Photovoltaic Systems, Inc., Princeton, New Jersey.

Stone, K.W., Lopez, C.W., McAlister R.E. (August 8-13, 1993). "Economic Performance of the SCE Stirling Dish," 28th Intersociety Energy Conversion Engineering Conference Proceedings. IECEC 1993. Atlanta, Georgia.

United Engineers \& Constrúctors Inc. (December 1992). Chino Battery Energy Storage Power Plant: Engineer-of-Record Report. EPRI/TR-101787. Electric Power Research Institute. Work performed by United Engineers \& Constructors Inc, Denver, Colorado, pp.4-56 and 4-60.

U.S. Department of Energy, Office of Conservation and Renewable Energy (October 1990). Renewable Energy Technology Evolution Rationales. SERI/TP-260-4427. DE91015016. Solar Energy Research Institute. 
U.S. Department of Energy Working Group on Energy Facility Siting (December 1993). Energy Infrastructure of the United States and Projected Siting Needs: Scoping Ideas, Identifying Issues and Options. DOE/PO-0005, Draft Report, pp. 79-80.

Vesterdaal, J. (1992). "Experience with Wind Farms in Demark," ELSAM, in The Potential of Wind Farms. EWEA Special Topic Conference, Herning, Demark. September 8-11, 1992.

Weisert, S. (March 7, 1994) Personal communication. Allis Engine Company.

Western Area Power Administration (April 1991). DSM Pocket Guidebook Volume 1: Residential Technologies. Solar Energy Research Institute. SERI/TP-254-4098A.

Western Area Power Administration (April 1991). DSM Pocket Guidebook Volume 2: Commercial Technologies. Solar Energy Research Institute. SERI/TP-254-4098B.

Wind Energy Weekly. Vol. 11, No. 489. March 16, 1992.

Zweibel, K. and Barnett, A.M. (1993). "Polycrystalline Thin-File Photovoltaics." in Renewable Energy: Sources for Fuels and Electricity. Johansson, T. et al. eds. Island Press, Washington, D.C. 


\subsection{Bibliography}

Aronsson, S. and Nilsson, P.-E. (May 1991). Learning from Experiences with Energy Efficient Lighting in Commercial Buildings, CADDET Analyses Series No. 6. Centre for the Analysis and Dissemination of Demonstrated Energy Technologies, The Netherlands.

Ahmed, K. (1994). Renewable Energy Technologies: A Review of the Status and Costs of Selected Technologies. World Bank Technical Paper Number 240, Energy Series. The World Bank, Washington, D.C.

Andrejko, D.A. (May 1989). Assessment of Solar Energy Technologies. American Solar Energy Society.

Appleby, A.J. and Foulkes, F.R. (1989). Fuel Cell Handbook. New York: Van Nostrand Reinhold.

Argonne National Laboratory (1990). Environmental Consequences of, and Control Processes for, Energy Technologies. Park Ridge, New Jersey: Noyes Data Corporation, pp. 419-451.

Atlantic Orient Corporation (July 1991). Advanced Wind Turbine Design Studies, Task 2, Improved Turbine Conceptual Study Report.

Bean, J.R. and Diver, R.B. (August 3-7, 1992). "The CPG 5-kW $\mathrm{e}_{\mathrm{e}}$ Dish-Stirling Development Program," 27th Intersociety Energy Conversion Engineering Conference Proceedings. IECEC 1992. San Diego, California.

Berndt, D. (1993). Maintenance-Free Batteries - Lead-Acid, Nickel/Cadmium, Nickel/Hydride - A Handbook of Battery Technology. Research Studies Press Ltd., Taunton, Somerset, England.

Blomen, L.J.M.J. and Mugerwa M.N., ed. (1993). Fuel Cell Systems. New York and London: Plenum Press.

Boes, E.C. and Luque, A. (1993). "Photovoltaic Concentrator Technology." Renewable Energy: Sources for Fuels and Electricity. Johansson, T. et al. eds. Island Press, Washington, D.C.

Butler, P.C. (February 1994). Utility Battery Storage Systems Program Report for FY 1993. Sandia National Laboratories, SAND93-3899.

Cairns, E.J. and McLarnon, F.R. (1993). "Status of Batteries for Energy Storage Applications," Proceedings of the Symposium on Batteries and Fuel Cells for Stationary and Electric Vehicle Applications. edited by Landgrebe, A.R. and Takehara, Z.

Carlson, D.E. and Wagner, S. (1993). "Amorphous Silicon Photovoltaic Systems." in Renewable Energy: Sources for Fuels and Electricity. Johansson, T. et al. eds. Washington, D.C.: Island Press.

Caterpillar Generator Set Specification Sheets (1992).

Davis, R.G. and Walsey, R.A. (June 1991). Guide to Performance Evaluation of Efficient Lighting Products, First Edition. Lighting Research Center Rensselaer Polytechnic Institute, Troy, NY. 
Department of Energy (April 1993). Solar Thermal Electric Five-Year Program Plan FT1993 through 1997. Solar Thermal and Biomass Power Division, Office of Solar Energy Conversion, DOE.

Detroit Diesel Engine Specification Sheets (1991).

Electric Power Research Institute (1985). Heat Pump Manual. EPRI EM-4110-SP, Special Report.

Electric Power Research Institute (June 1988). Design and Costs for a Generic 10-MW Utility Lead-Acid Battery Energy Storage Plant. AP-5845, Final Report.

Electric Power Research Institute (March 1993). Chino Battery Energy Storage Plant, Vol. 1. TR101787, Final Report.

Electric Power Research Institute (March 1993). Field Experience with Photovoltaic Systems: Ten-Year Assessment. EPRI TR-102138, Final Report.

Electric Power Research Institute (August 1993). Principles and Practice of Demand-Side Management, EPRI TR-102556.

Firor, K., Vigotti, R. and Iannucci, J. (1993). "Utility Field Experience with Photovoltaic Systems," in Renewable Energy . Sources for fuels and Electricity. Johansson, T. et al. eds. Island Press, Washington, D.C.

Fiss, H-J. et al. (1993). "Connection of Wind Power Generation Facilities to the Power Distribution System and Potential Effects on the System" in Proceedings of 1993 European Community Wind Energy Conference. Lübeck-Travemünde, Germany. March 8-12, 1993.

Gellings, C.W. and Chamberlin, J.H. (1993). Demand-Side Management: Concepts and Methods. 2nd Edition. The Fairmont Press, Inc. Lilburn, Georgia.

Lienau, P.J. (April 1994). "Geothermal Heat Pump Performance and Utility Programs," DOE Geothermal Program Review XII, April 25-28, 1994, San Francisco, California. DOE/GO10094-005.

Lynette, R., Young, J. and Conover, K. (1989). Experience with Commercial Wind Turbine Design. EPRI GS-6245, Electric Power Research Institute.

Lynette, R. (January 1992). Advanced Wind Turbine Conceptual Study. R. Lynette \& Associates. Draft Final Report.

Nadel, S. and Geller, H. (July 1991). Efficiency Standards for Lamps, Motors, Commercial HVAC Equipment and Showerheads: Recommendations for State Action. American Council for an EnergyEfficient Economy.

National Renewable Energy Laboratory (October 1991). Photovoltaics Program Plan FY1991-FY1995. Department of Energy, DOE/CH10093-92.

Pietsch, J:A. (1988). Water-Loop Heat Pump Systems: Assessment Study. Electric Power Research Institute, EPRI EM-5437. 
Randall, A. and Sanchez, J. "Engineering and Design Criteria for a Battery Electric Storage System (BSEE)." Proceedings of the Fifth International Lead-Acid Battery Seminar, April 17-19, 1991, Vienna, VA.

Sandia National Laboratories (January 1993). Utility Battery Storage Systems Program Report for FY92. SAND-92-2272.

Stork-Wärtsilä Diesel Engine Specification Sheets (1992).

Sullivan, W.N. (April 1994). "The Sandia/DOE Program on Geothermal Heat Pumps," DOE Geothermal Program Review XII, April 25-28, 1994, San Francisco, California. DOE/GO10094-005.

Swift, A., Hock, S., and Thresher, R. (1993). "Advanced Wind Turbine Performance and Cost Projections: A Configuration Survey," The 16th Annual Energy-Sources Technology Conference and Exhibition, Houston, Texas. January 31-February 4, 1993.

Westinghouse Electric Corporation (October, 1992). The Westinghouse Solid Oxide Fuel Cell Program -A 1992 Progress Report. October 1992.

Willis, H.L., et al. (August 1990). DSM: Transmission and Distribution Impacts Volume 1: Analysis Framework and Test Case. EPRI CU-6924 Volume 1 and 2. Electric Power Research Institute. Final Report.

World Information Technologies Inc. (September 1992). Photovoltaics World Market, Technologies, and Opportunities in Solar Cells and Modules 1992-2000 Analysis. Northport, New York. 
Appendix

Distributed Utility Technology Environmental Forms 


\section{DU Technology Environmental Form}

\begin{tabular}{|c|c|c|c|c|c|}
\hline Technology: & \multicolumn{3}{|c|}{ DDC 1050 Diesel Generator Set } & Status: & nercial \\
\hline Manufacturer: & \multicolumn{5}{|c|}{ Detroit Diesel Power Systems } \\
\hline Capacity (kW): & 1050 & Heatrate (Btu/kWh): & 9114 & Maximum Temperature (K): & 672 \\
\hline
\end{tabular}

Physical Characteristi s of Plant

\begin{tabular}{|l|c|}
\hline Land Area Reguired (ba) & -0.002 \\
\hline IStructural FootPrint (m^2) & -9.3 \\
\hline Structural Height (m) & 1.8 \\
\hline Stack Height (m) & 2.7 \\
\hline Plant Lighting (Yes/No) & $\mathrm{N}$ \\
\hline Security Fence (Yes/No) & $\mathrm{Y}$ \\
\hline Security Lighting (Yes/No) & $\mathrm{Y}$ \\
\hline
\end{tabular}

\section{E issions During Plant Operation}

Combustion Emissions

\begin{tabular}{|c|c|c|}
\hline CO & 1.5 & $(\mathrm{~b} / \mathrm{mmBtu})$ \\
\hline $\mathrm{CO} 2$ & $150(\mathrm{a})$ & $(\mathrm{b} / \mathrm{mmBtu})$ \\
\hline NOx & 2.76 & $(\mathrm{~b} / \mathrm{mmBtu})$ \\
\hline SO2 & $0.3(\mathrm{a})$ & $(\mathrm{b} / \mathrm{mmBtu})$ \\
\hline HC & 0.14 & $(\mathrm{~b} / \mathrm{mmBtu})$ \\
\hline PM & $0.08(\mathrm{a})$ & $(\mathrm{b} / \mathrm{mmBtu})$ \\
\hline Control Technology & none \\
\hline
\end{tabular}

FueVChemical Requirements:

\begin{tabular}{|l|c|}
\hline Primary Fuel & Diesel \\
\hline Fuel Transportation Method & Truck \\
\hline Primary Chemical & N/A \\
\hline Chemical Transportation Method & N/A \\
\hline Fuel/Chemical Storage (Yes/No) & Yes \\
\hline $\begin{array}{l}\text { Fuel/Chemical Storage Characteristics: } \\
\text { Diesel stored in tank. }\end{array}$ & \\
\hline
\end{tabular}

Significant Liquid Emissions

\begin{tabular}{|l|}
\hline N/A \\
\hline Significant Solid Emissions \\
\hline N/A \\
\hline Noise Generated at Peak Capacity (dB) \\
Note: Can be reduced by installing silencers. \\
\hline
\end{tabular}

\section{Regulatory Authorities and Issues}

That May Impact the Siting Process

Federal Authority

\begin{tabular}{|l|c|}
\hline Clean Air Act & X \\
\hline State Authority & \\
\hline State Environmental Quality Act & $\mathrm{X}$ \\
\hline Local Authority (County or City) & \\
\hline Air Quality Management District & $\mathrm{X}$ \\
\hline Planning Commission (zoning) & $\mathrm{X}$ \\
\hline Water & $\mathrm{X}$ \\
\hline Sewage & $\mathrm{X}$ \\
\hline Building and Electrical & $\mathrm{X}$ \\
\hline Occupancy & \\
\hline Not In My Back Yard (NMMBY) & $\mathrm{X}$ \\
\hline
\end{tabular}

Primary Technology Reference

Detroit Diesel Power Systems. (1991). Engine

Specification Data; Product Information from Sales

Brochure. Detroit, Michigan.

Secondary References

(a) U.S. Environmental Protection Agency. (September 1985). Compilation of Air Pollutant Emission Factors; Vol. 1, Stationary Point and Area Sources. Research Triangle Park, North Carolina. p. 3.4-3. 


\section{DU Technology Environmental Form}

\begin{tabular}{|c|c|c|c|c|c|c|}
\hline Technology: & \multicolumn{4}{|c|}{ Generic Dual Fuel (NG \& Diesel) Intemal Combustion Engine } & Status: & Commercial \\
\hline Manufacturer: & \multicolumn{6}{|c|}{ Generic Description - No Manufacturer Specified } \\
\hline Capacity $(\mathrm{kW})$ : & 1000 & Heatrate (Btu/kWh): & 9500 & Maximu & are $(\mathrm{K})$ : & 700 \\
\hline
\end{tabular}

Time Required for Installation/Construction (Yr):

0.5

Physical Characteristics of Plant

\begin{tabular}{|l|c|}
\hline Land Area Required (ha) & -0.002 \\
\hline IStructural FootPrint (m^2) & $\sim 9.3$ \\
\hline Structural Height (m) & 1.8 \\
\hline Stack Height (m) & 2.7 \\
\hline Plant Lighting (Yes/No) & N \\
\hline Security Fence (Yes/No) & Y \\
\hline Security Lighting (Yes/No) & Y \\
\hline
\end{tabular}

Emissions During Plant Operation Combustion Emissions

\begin{tabular}{|c|c|c|}
\hline CO & 0.79 & $($ (b/mmBtu $)$ \\
\hline CO2 & 110 & $($ (b/mmBtu $)$ \\
\hline NOx & 3.1 & $($ (b/mmBtu $)$ \\
\hline SO2 & 0.015 & $($ (b/mmBtu $)$ \\
\hline HC & 0.8 & $($ (b/mmBtu) \\
\hline PM & 0.08 & $($ (b/mmBtu $)$ \\
\hline Control Technology & none \\
\hline
\end{tabular}

\section{Fuel/Chemical Requirements:}

\begin{tabular}{|l|c|}
\hline Primary Fuel & NG \\
\hline Fuel Transportation Method & Pipeline \\
\hline Primary Chemical & N/A \\
\hline Chemical Transportation Method & N/A \\
\hline Fuel/Chemical Storage (Yes/No) & N/A \\
\hline Fuel/Chemical Storage Characteristics: & N/A \\
& \\
\hline
\end{tabular}

\section{Significant Liquid Emissions}

$$
\text { N/A }
$$

Significant Solid Emissions

$$
\text { N/A }
$$

\section{Regulatory Authorities and Issues}

That May Impact the Siting Process

\begin{tabular}{|}
\hline Federal Authority \\
\begin{tabular}{|l|c|}
\hline Clean Air Act & X \\
\hline State Authority \\
\hline State Environmental Quality Act & X \\
\hline Local Authority (County or City) & \\
\hline Air Quality Management District & X \\
\hline Planning Commission (zoning) & X \\
\hline Water & X \\
\hline Sewage & X \\
\hline Building and Electrical & X \\
\hline Occupancy & \\
\hline Not In My Back Yard (NMMBY) & X \\
\hline
\end{tabular}
\end{tabular}

Brimary Technology Reference

U.S. Environmental Protection Agency. (September 1985). Compilation of Air Pollutant Emission Factors; Vol. 1, Stationary Point and Area Sources. Research Triangle Park, North Carolina. p. 3.4-3. 


\section{DU Technology Environmental Form}

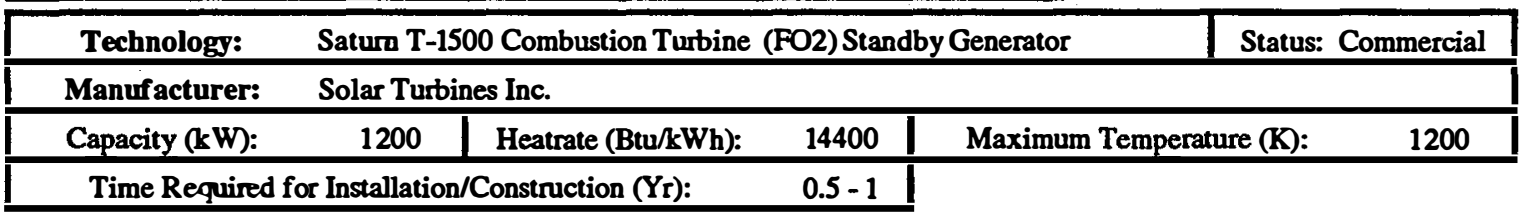

Physical Characteristics of Plant

\begin{tabular}{|l|c|}
\hline Land Area Required (ha) & -0.002 \\
\hline Structural FootPrint (m^2) & 9.5 \\
\hline Structural Height (m) & 1.8 \\
\hline Stack Height (m) & 5.5 \\
\hline Plant Lighting (Yes/No) & $\mathrm{N}$ \\
\hline Security Fence (Yes/No) & $\mathrm{Y}$ \\
\hline Security Lighting (Yes/No) & $\mathrm{Y}$ \\
\hline
\end{tabular}

Fuel/Chemical Requirements:

\begin{tabular}{|l|c|}
\hline Primary Fuel & Fuel Oil \#2 \\
\hline Fuel Transportation Method & Truck \\
\hline Primary Chemical & N/A \\
\hline Chemical Transportation Method & N/A \\
\hline Fuel/Chemical Storage (Yes/No) & Yes \\
\hline $\begin{array}{l}\text { Fuel/Chemical Storage Characteristics: } \\
\text { Unpressurized liquid fuel stored in tank. }\end{array}$ \\
\hline
\end{tabular}

\section{Emissions During Operation}

Combustion Emissions

\begin{tabular}{|c|c|c|}
\hline $\mathrm{CO}$ & 0.12 (a) & (lb/mmBtu) \\
\hline $\mathrm{CO} 2$ & 164 (a) & (lb/mmBtu) \\
\hline NOx & 0.61 (a) & (lb/mmBtu) \\
\hline $\mathrm{SO} 2$ & 0.2 (a) & (b/mmBtu) \\
\hline HC & 0.04 (a) & (b/mmBtu) \\
\hline PM & 0.03 (a) & (b/mmBtu) \\
\hline \multicolumn{2}{|c|}{ Control Technology } & None \\
\hline
\end{tabular}

Significant Liquid Emissions

\begin{tabular}{|l|}
\hline N/A \\
\hline Significant Solid Emissions \\
\hline N/A \\
\hline Noise: shielding and silencer can be installed \\
to meet most site requirements.
\end{tabular}

\section{Regulatory Authorities and Issues}

That May Impact the Siting Process

\begin{tabular}{|}
\hline Federal Authority \\
\hline Clean Air Act & X \\
\hline State Authority \\
\hline State Environmental Quality Act \\
\hline Local Authority (County or City) & X \\
\hline Air Quality Management District & \\
\hline Planning Commission (zoning) & X \\
\hline Water & X \\
\hline Sewage & X \\
\hline Building and Electrical & X \\
\hline Occupancy & X \\
\hline Not In My Back Yard (NDMBY) & \\
\hline
\end{tabular}

Primary Technology Reference

Solar Turbines Incorporated. (1993). Gas Turbine

Systems for Generator Applications; Product Information

from Sales Brochure. San Diego, California

Secondary References

(a) National Renewable Energy Laboratory. (March 1993).

Environmental Characterization Database Phase II:

Utility and Transportation Data. Washington, D.C.: U.S. Department of Energy, Office of Conservation and Renewable Energy, Offec of Planning and Assessment. Prepared by National Renewable Energy Laboratory, Analytic Studies Division, Golden, Colorado. 


\section{DU Technology Environmental Form}

Technology: $\quad$ Satum T-1500 Combustion Turbine (NG) Standby Generator

Status: Commercial

Manufacturer: Solar Turbines Inc.

\begin{tabular}{ll|ll|ll} 
Capacity $(\mathrm{kW}):$ & 1200 & Heatrate $(B t u / \mathrm{kWh}):$ & 14400 & Maximum Temperature (K): & 1200
\end{tabular}

Time Required for Installation/Construction (Yr):

$0.5-1$

Physical Characteristics of Plant

\begin{tabular}{|l|c|}
\hline Land Area Required (ha) & -0.002 \\
\hline Structural FootPrint (m^2) & 9.5 \\
\hline IStructural Height (m) & 1.8 \\
\hline Stack Height (m) & 5.5 \\
\hline Plant Lighting (Yes/No) & $\mathrm{N}$ \\
\hline Security Fence (Yes/No) & $\mathrm{Y}$ \\
\hline Security Lighting (Yes/No) & $\mathrm{Y}$ \\
\hline
\end{tabular}

Emissions During Plant Operation

Combustion Emissions

\begin{tabular}{|c|c|c|}
\hline CO & 0.11 (a) & $(\mathrm{b} / \mathrm{mmBtu})$ \\
\hline CO2 & 119 (a) & $(\mathrm{b} / \mathrm{mmBtu})$ \\
\hline NOx & 0.4 (a) & $(\mathrm{b} / \mathrm{mmBtu})$ \\
\hline SO2 & 0.0006 (a) & $(\mathrm{b} / \mathrm{mmBtu})$ \\
\hline HC & 0.012 (a) & $(\mathrm{lb} / \mathrm{mmBtu})$ \\
\hline PM & 0.013 (a) & $(\mathrm{b} / \mathrm{mmBtu})$ \\
\hline Control Technology & None \\
\hline
\end{tabular}

Fuel/Chemical Requirements:

\begin{tabular}{|l|c|}
\hline Primary Fuel & Natural Gas \\
\hline Fuel Transportation Method & Pipeline \\
\hline Primary Chemical & N/A \\
\hline Chemical Transportation Method & N/A \\
\hline Fuel/Chemical Storage (Yes/No) & None \\
\hline $\begin{array}{l}\text { Fuel/Chemical Storage Characteristics: } \\
\text { No fuel storage necessary. }\end{array}$ \\
\hline
\end{tabular}

Significant Liquid Emissions

\begin{tabular}{|l|}
\hline N/A \\
Significant Solid Emissions \\
N/A
\end{tabular}

Noise: shielding and silencer can be installed

to meet most site requirements.

Regulatory Authorities and Issues

That May Impact the Siting Process

Federal Authority

\begin{tabular}{|l|c|}
\hline Clean Air Act & X \\
\hline State Authority & \\
\hline State Environmental Quality Act & $\mathrm{X}$ \\
\hline Local Authority (County or City) & \\
\hline Air Quality Management District & $\mathrm{X}$ \\
\hline Planning Commission (zoning) & $\mathrm{X}$ \\
\hline Water & $\mathrm{X}$ \\
\hline Sewage & $\mathrm{X}$ \\
\hline Building and Electrical & $\mathrm{X}$ \\
\hline Occupancy & \\
\hline Not In My Back Yard (NMMBY) & $\mathrm{X}$ \\
\hline
\end{tabular}

Primary Technology Reference

Solar Turbines Incorporated. (1993). Gas Turbine Systems for Generator Applications; Product Information from Sales Brochure. San Diego, California. Secondary References

(a) National Renewable Energy Laboratory. (March 1993). Environmental Characterization Database Phase II: Utility and Transportation Data. Washington, D.C.: U.S. Department of Energy, Office of Conservation and Renewable Energy, Office of Planning and Assessment. Prepared by National Renewable Energy Laboratory, Analytic Studies Division, Golden, Colorado. 


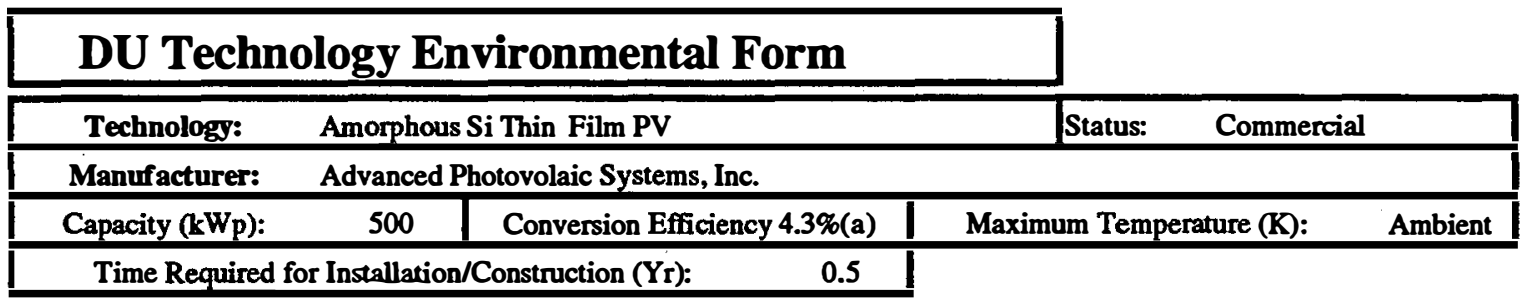

Physical Characteristics of Plant

\begin{tabular}{|l|c|}
\hline Land Area Required (ha) & $\sim 2$ \\
\hline FootPrint (ha) & $\sim 1.2$ \\
\hline Structural Height (m) & $\sim 8.5$ \\
\hline Stack Height (m) & N/A \\
\hline Plant Lighting (Yes/No) & N \\
\hline Security Fence (Yes/No) & Y \\
\hline Security Lighting (Yes/No) & Y \\
\hline
\end{tabular}

\section{Emissions During Plant Operation}

Combustion Emissions

\begin{tabular}{|c|c|c|}
\hline CO & N/A & $($ (b/mmBtu $)$ \\
\hline CO2 & N/A & $($ (b/mmBtu $)$ \\
\hline NOx & N/A & $($ (b/mmBtu $)$ \\
\hline SO2 & N/A & $($ (b/mmBtu $)$ \\
\hline HC & N/A & $($ (b/mmBtu $)$ \\
\hline PM & N/A & $($ (b/mmBtu $)$ \\
\hline Control Technology & N/A \\
\hline
\end{tabular}

\section{Fuel/Chemical Requirements:}

\begin{tabular}{|l|l|}
\hline Primary Fuel & N/A \\
\hline Fuel Transportation Method & N/A \\
\hline Primary Chemical & N/A \\
\hline Chemical Transportation Method & N/A \\
\hline Fuel/Chemical Storage (Yes/No) & N/A \\
\hline Fuel/Chemical Storage Characteristics: & N/A \\
& \\
\hline
\end{tabular}

\section{Significant Liquid Emissions}

Water (w/detergent) used to wash dust from PV arrays.

Water (w/herbicides) used for weed control.

\section{Significant Solid Emissions}

N/A

Noise Generated at Peak Capacity (dB)

\section{Regulatory Authorities and Issues}

That May Impact the Siting Process

\begin{tabular}{|}
\hline Federal Authority \\
\hline Clean Air Act \\
\hline State Authority \\
\hline State Environmental Quality Act \\
\hline Local Authority (County or City) & X \\
\hline Air Quality Management District & \\
\hline Planning Commission (zoning) & \\
\hline Water & X \\
\hline Sewage & X \\
\hline Building and Electrical & \\
\hline Occupancy & X \\
\hline Not In My Back Yard (NDMBY) & \\
\hline
\end{tabular}

Primary Technology Reference

Shugar, D. (15 February 1994). Personal Comununication. Advanced Photovoltaic Systems, Inc. Princeton, New Jersey.

Secondary References

(a) Advanced Photovoltaic Systems, Inc. (1992). APS ENSO Thin Film Photovoltaic Module Specifications; Product Information from Sales Brochure. Fairfield, California. Note: efficiency for module only and does not include balance of system. 


\section{DU Technology Environmental Form}

\begin{tabular}{|c|c|c|c|c|c|}
\hline Technology: & \multicolumn{3}{|c|}{ Crystal Silicon framed glass laminate; 1 axis horz. tracking } & Status: & Commercial \\
\hline Manufacturer: & \multicolumn{5}{|c|}{ Siemens Solar } \\
\hline Capacity (kWp): & 500 & Conversion Efficiency $9.4 \%$ & Maxim & Ire (K): & Ambient \\
\hline
\end{tabular}

Physical Characteristics of Piant

Land Area Required (ha)

Structural FootPrint (ha)

Structural Height (m)

Stack Height (m)

Plant Lighting (Yes/No)

Security Fence (Yes/No)

Security Lighting (Yes/No)
FueVChemical Requirements:

\begin{tabular}{|l|l|}
\hline Primary Fuel & N/A \\
\hline Fuel Transportation Method & N/A \\
\hline Primary Chemical & N/A \\
\hline Chemical Transportation Method & N/A \\
\hline Fuel/Chemical Storage (Yes/No) & N/A \\
\hline Fuel/Chemical Storage Characteristics: & N/A \\
& \\
\hline
\end{tabular}

Emissions During Plant Operation Combustion Emissions

\begin{tabular}{|c|c|c|}
\hline CO & N/A & $(\mathrm{b} / \mathrm{mmBtu})$ \\
\hline CO2 & N/A & $(\mathrm{b} / \mathrm{mmBtu})$ \\
\hline NOx & N/A & $(\mathrm{b} / \mathrm{mmBtu})$ \\
\hline SO2 & N/A & $(\mathrm{b} / \mathrm{mmBtu})$ \\
\hline HC & N/A & $(\mathrm{b} / \mathrm{mmBtu})$ \\
\hline PM & N/A & $(\mathrm{b} / \mathrm{mmBtu})$ \\
\hline Control Technology & N/A \\
\hline
\end{tabular}

\section{Significant Liquid Emissions}

Water (w/detergent) used to wash dust from PV arrays.

Water w/herbicides used for weed control.

Significant Solid Emissions

$$
\text { N/A }
$$

Noise Generated at Peak Capacity (dB)

\section{Regulatory Authorities and Issues}

That May Impact the Siting Process

\begin{tabular}{l}
\hline Federal Authority \\
\begin{tabular}{|l|c|}
\hline Clean Air Act & \\
\hline State Authority & \\
\hline State Environmental Quality Act & X \\
\hline Local Authority (County or City) & \\
\hline Air Quality Management District & \\
\hline Planning Commission (zoning) & X \\
\hline Water & X \\
\hline Sewage & \\
\hline Building and Electrical & X \\
\hline Occupancy & \\
\hline Not In My Back Yard (NMMBY) & X \\
\hline
\end{tabular}
\end{tabular}

Primary Technology Reference

Shugar, D. S. and Thomas, H.E. (1993). "Grid-support

Photovoltaics: Evaluation of Criteria and Methods to Assess Empirically the Local and System Benefits to Electric Utilities." Progress in Photovoltaic Research and Applications; Vol. 1, pp. 233-250. 


\section{DU Technology Environmental Form}

\begin{tabular}{|cl|l|l|}
\hline Technology: & Lead-Acid Battery Energy Storage Power Plant & Status: & Commercial \\
\hline Owner/Operator: & Southern California Edison & & \\
\hline Capacity: & $10 \mathrm{MW}-4 \mathrm{hr}$ battery storage & Maximum Temperature (K): & Ambient \\
\hline Time Required for Installation/Construction (Yr): & 1 & & \\
\hline
\end{tabular}

Physical Characteristics of Plant

\begin{tabular}{|l|c|}
\hline Land Area Reguired (ha) & $\sim 0.61$ \\
\hline Structural FootPrint (ha) & 0.51 \\
\hline Structural Height (m) & 4.6 \\
\hline Stack Height (m) & N/A \\
\hline Plant Lighting (Yes/No) & Y \\
\hline Security Fence (Yes/No) & Y \\
\hline Security Lighting (Yes/No) & Y \\
\hline
\end{tabular}

Fuel/Chemical Requirements:

\begin{tabular}{|l|c|}
\hline Primary Fuel & N/A \\
\hline Fuel Transportation Method & N/A \\
\hline Primary Chemical & Deionized Water \\
\hline Chemical Transportation Method & N/A \\
\hline Fuel/Chemical Storage (Yes/No) & Y \\
\hline $\begin{array}{l}\text { Fuel/Chemical Storage Characteristics: } \\
\text { to store deionized water that is required at an average rate } \\
\text { of 32816 L/month to water the lead-acid batteries. }\end{array}$ \\
\hline
\end{tabular}

Emissions During Plant Operation

Combustion Emissions

\begin{tabular}{|c|c|c|}
\hline CO & N/A & $(\mathrm{b} / \mathrm{mmBtu})$ \\
\hline CO2 & N/A & $(\mathrm{b} / \mathrm{mmBtu})$ \\
\hline NOx & N/A & $(\mathrm{b} / \mathrm{mmBtu})$ \\
\hline SO2 & N/A & $(\mathrm{b} / \mathrm{mmBtu})$ \\
\hline HC & N/A & $(\mathrm{b} / \mathrm{mmBtu})$ \\
\hline PM & N/A & $(\mathrm{b} / \mathrm{mmBtu})$ \\
\hline Control Technology & N/A \\
\hline
\end{tabular}

\section{Significant Liquid Emissions}

The battery electrolyte is sulfuric-acid. Even though emissions of the
dectrolyte would occur only under failure conditions, a containment
system is still required to eliminate the passiblility of ground water
contamination.
Significant Solid Emissions
N/A

Noise Generated at Peak Capacity (dB)

\section{Regulatory Authorities and Issues}

That May Impact the Siting Process

\begin{tabular}{|c|c|}
\hline \multicolumn{2}{|l|}{ Federal Authority } \\
\hline Clean Air Act & $\mathbf{X}$ \\
\hline \multicolumn{2}{|l|}{ State Authority } \\
\hline State Environmental Quality Act & $\mathbf{X}$ \\
\hline \multicolumn{2}{|l|}{ Local Authority (County or City) } \\
\hline Air Quality Management District & $\mathbf{X}$ \\
\hline Planning Commission (zoning) & $\mathbf{X}$ \\
\hline Water & $\mathbf{X}$ \\
\hline Sewage & $\mathbf{X}$ \\
\hline Building and Electrical & $\mathbf{X}$ \\
\hline Occupancy & $\mathbf{X}$ \\
\hline Not In My Back Yard (NIMBY) & $\mathbf{X}$ \\
\hline
\end{tabular}

Primary Technology Reference Rowell, W.H. (December 1992). Chino Battery Energy Storage Power Plant: Engineer-of-Record Report. EPRIIR-101787. Palo Alto, California: Electric Power Research Institute. Work performed by United Engineers \& Constructors, Inc., Denver, Colorado. 


\section{DU Technology Environmental Form}

\begin{tabular}{|c|c|c|c|c|c|c|}
\hline Technology: & Phospho & cid Fuel Cell & & Status: & Commer & \\
\hline Manufacturer: & \multicolumn{6}{|c|}{ ONSI, a Subsidiary of Intemational Fuel Cell Corporation } \\
\hline Capacity (kW): & 200 & Heatrate (Btu/kWh): & 8550 & Maximum Tem & ature (K): & 473 \\
\hline
\end{tabular}

Physical Chara teristi s of Plant

\begin{tabular}{|l|c|}
\hline Land Area Required (ha) & $\sim 0.02$ \\
\hline Structural FootPrint (m^2) & 83.6 \\
\hline Structural Height (m) & 3.7 \\
\hline Stack Height (m) & 4.1 \\
\hline Plant Lighting (Yes/No) & $\mathrm{N}$ \\
\hline Security Fence (Yes/No) & $\mathrm{Y}$ \\
\hline Security Lighting (Yes/No) & $\mathrm{Y}$ \\
\hline
\end{tabular}

\section{Emissions During Plant Operation}

Combustion Emissions

\begin{tabular}{|c|c|c|}
\hline CO & 0.2 & $(\mathrm{~b} / \mathrm{mmBtu})$ \\
\hline $\mathrm{CO} 2$ & Unloown & $(\mathrm{b} / \mathrm{mmBtu})$ \\
\hline $\mathrm{NOx}$ & 0.02 & $(\mathrm{~b} / \mathrm{mmBtu})$ \\
\hline $\mathrm{SO}$ & 0.00003 & $(\mathrm{bb} / \mathrm{mmBtu})$ \\
\hline $\mathrm{HC}$ & 0.02 & $(\mathrm{~b} / \mathrm{mmBtu})$ \\
\hline PM & $3.00 \mathrm{E}-06$ & $(\mathrm{~b} / \mathrm{mmBtu})$ \\
\hline Control Technology & None \\
\hline
\end{tabular}

\section{Fuel/Chemical Requirements:}

\begin{tabular}{|l|c|}
\hline Primary Fuel & Natural Gas \\
\hline Fuel Transportation Method & Pipeline \\
\hline Primary Chemical & N/A \\
\hline Chemical Transportation Method & N/A \\
\hline Fuel/Chemical Storage (Yes/No) & N \\
\hline Fuel/Chemical Storage Characteristics: & N/A \\
\hline
\end{tabular}

Significant Liquid Emissions

Water condensate(0 - 1.9 LPM). Water is treated and lowered to temperatures that allow it to be discharged to sewer facilities. Slgnificant Solid Emissions

$$
\text { N/A }
$$

Noise Generated at Peak Capacity (dB)

\section{Regulatory Authorities and Issues}

That May Impact the Siting Process

\begin{tabular}{|l|c|}
\hline Federal Authority \\
\hline Clean Air Act & $\mathrm{X}$ \\
\hline State Authority \\
\hline State Environmental Quality Act & \\
\hline Local Authority (County or City) & $\mathrm{X}$ \\
\hline Air Quality Management District & \\
\hline Planning Commission (zoning) & $\mathrm{X}$ \\
\hline Water & $\mathrm{X}$ \\
\hline Sewage & $\mathrm{X}$ \\
\hline Building and Electrical & $\mathrm{X}$ \\
\hline Occupancy & $\mathrm{X}$ \\
\hline Not In My Back Yard (NDMBY) & \\
\hline
\end{tabular}

Primary Technology Reference International Fuel Cells. (August 1986). The PC25 Fuel Cell Power Plant. International Fuel Cells Product Brochure, South Windsor, Connecticut. 


\section{DU Technology Environmental Form}

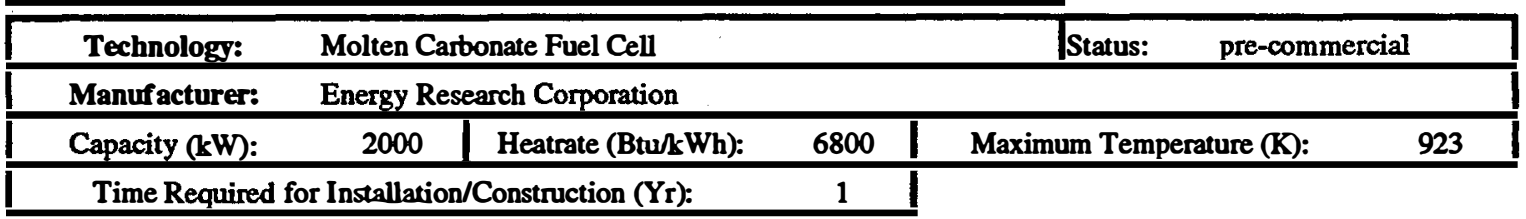

Physical Chara teristics of Plant

\begin{tabular}{|l|c|}
\hline Land Area Required (ha) & $\sim 0.06$ \\
\hline Structural FootPrint (m^2) & 418.1 \\
\hline Structural Height (m) & 3.7 \\
\hline Stack Height (m) & 5.5 \\
\hline Plant Lighting (Yes/No) & Y \\
\hline Security Fence (Yes/No) & Y \\
\hline Security Lighting (Yes/No) & Y \\
\hline
\end{tabular}

Emissions During Plant Operation

Combustion Emissions

\begin{tabular}{|c|c|c|}
\hline CO & Unknown & $(\mathrm{b} / \mathrm{mmBtu})$ \\
\hline CO2 & Unknown & $(\mathrm{b} / \mathrm{mmBtu})$ \\
\hline NOx & 0.0027 & $(\mathrm{~b} / \mathrm{mmBtu})$ \\
\hline SO2 & 0.0204 & $(\mathrm{~b} / \mathrm{mmBtu})$ \\
\hline HC & Unknown & $(\mathrm{b} / \mathrm{mmBtu})$ \\
\hline PM & Unknown & (b/mmBtu $)$ \\
\hline Control Technology & None \\
\hline
\end{tabular}

FuelChemi al Requirements:

\begin{tabular}{|l|c|}
\hline Primary Fuel & Natural Gas \\
\hline Fuel Transportation Method & Pipeline \\
\hline Primary Chemical & Water (416 L/hr) \\
\hline Chemical Transportation Method & Pipeline \\
\hline Fuel/Chemical Storage (Yes/No) & No \\
\hline Fuel/Chemical Storage Characteristics: & N/A \\
\hline
\end{tabular}

Significant Liquid Emissions

\section{N/A}

Significant Solid Emissions

N/A

Noise Generated at Peak Capacity (dB)

0

\section{Regulatory Authorities and Issues}

That May Impact the Siting Process

\begin{tabular}{|l|c|}
\hline Federal Authority & X \\
\hline Clean Air Act & \\
\hline State Authority & X \\
\hline State Environmental Quality Act & \\
\hline Local Authority (County or City) & X \\
\hline Air Quality Management District & X \\
\hline Planning Commission (zoning) & X \\
\hline Water & X \\
\hline Sewage & X \\
\hline Building and Electrical & X \\
\hline Occupancy & X \\
\hline Not In My Back Yard (NMB Y) & \\
\hline
\end{tabular}

Primary Technology Reference

El-Gasseir, M.M. (May 1992). Molten Carbonate Fuel Cells as Distributed-Generation Resources: Case Studies for the Los Angeles Department of Water and Power. EPRI/R-100686. Palo Alto, California: Electric Power Research Institute. Work Performed by M.M. El-Gasseir, Private Contractor, Lafayette, California. 


\section{DU Technology Environmental Form}

\begin{tabular}{|c|c|c|c|}
\hline Technology: & Dish-Stirling Free Piston Electric & Status: \\
\hline Manufacturer: & Cummins Power Generation, Inc. & pre-commercial \\
\hline Capacity (kWp): & 7.5 & Conversion Efficiency 20\% & Maximum Temperature (K): \\
\hline Time Required for Installation/Construction (Yr): & 1 & \\
\hline
\end{tabular}

Physical Characteristi s of Piant

\begin{tabular}{|l|c|}
\hline Land Area Reguired (ba) & $\sim 0.02$ \\
\hline Dish FootPrint (m^2) & 83.6 \\
\hline Structural Height (m) & 9.1 \\
\hline Stack Height (m) & N/A \\
\hline Plant Lighting (Yes/No) & N \\
\hline Security Fence (Yes/No) & Y \\
\hline Security Lighting (Yes/No) & Y \\
\hline
\end{tabular}

\section{Emissions During Plant Operation}

Combustion Emissions

\begin{tabular}{|c|c|c|}
\hline CO & N/A & $($ b/mmBtu $)$ \\
\hline CO2 & N/A & $($ b/mmBtu $)$ \\
\hline NOx & N/A & $($ b/mmBtu $)$ \\
\hline SO2 & N/A & $($ b/mmBtu $)$ \\
\hline HC & N/A & $($ b/mmBtu $)$ \\
\hline PM & N/A & $(\mathrm{b} / \mathrm{mmBtu})$ \\
\hline Control Technology & N/A \\
\hline
\end{tabular}

\section{Fuel/Chemical Requirements:}

\begin{tabular}{|l|l|}
\hline Primary Fuel & N/A \\
\hline Fuel Transportation Method & N/A \\
\hline Primary Chemical & N/A \\
\hline Chemical Transportation Method & N/A \\
\hline Fuel/Chemical Storage (Yes/No) & N/A \\
\hline Fuel/Chemical Storage Characteristics: & N/A \\
\end{tabular}

\section{Significant Liquid Emissions}

Water (w/detergent) used to wash dust from reflective dishes.

Water(w/herbicides) used for weed control.

\section{Significant Solid Emissions}

Solid/liquid sodium metal is present in the stirling heat engine.

The sodium would be released to the environment only under extreme

failure conditions.

Noise Generated at Peak Capacity (dB)

\section{Regulatory Authorities and Issues}

That May Impact the Siting Pro ess

\section{Federal Authority}

\begin{tabular}{|}
\hline Clean Air Act \\
\begin{tabular}{|l|c|}
\hline State Authority \\
\hline State Environmental Quality Act & X \\
\hline Local Authority (County or City) & \\
\hline Air Quality Management District & \\
\hline Planning Commission (zoning) & X \\
\hline Water & X \\
\hline Sewage & X \\
\hline Building and Electrical & X \\
\hline Occupancy & \\
\hline Not In My Back Yard (NDMBY) & X \\
\hline
\end{tabular} \\
\hline
\end{tabular}

Brimary Technology Reference

Bean, J.R. and Diver, R.B. (1993). "Performance of the CPG 7.5-KWe Dish-Stiding System." IEC Paper No. IEC054. 


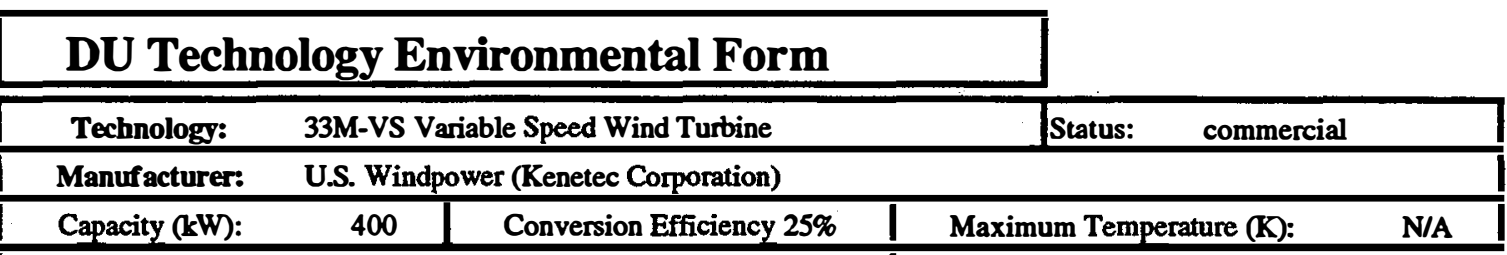

Time Required for Installation/Construction (Yr):

0.5

Physical Chara teristi s of Plant
\begin{tabular}{|l|c|}
\hline Land Area Reguired (ha)(b) & 5.4 \\
\hline Structural FootPrint (m^2) & 855 \\
\hline Structural Height (m) & 46.3 \\
\hline Stack Height (m) & N/A \\
\hline Plant Lighting (Yes/No) & N \\
\hline Security Fence (Yes/No) & Y \\
\hline Security Lighting (Yes/No) & Y \\
\hline
\end{tabular}

Fuel/Chemical Requirements:

\begin{tabular}{|l|l|}
\hline Primary Fuel & N/A \\
\hline Fuel Transportation Method & N/A \\
\hline Primary Chemical & N/A \\
\hline Chemical Transportation Method & N/A \\
\hline Fuel/Chemical Storage (Yes/No) & N/A \\
\hline Fuel/Chemical Storage Characteristics: & N/A \\
& \\
\hline
\end{tabular}

Emissions During Piant Operation

Combustion Emissions

\begin{tabular}{|c|c|c|}
\hline CO & N/A & $(\mathrm{b} / \mathrm{mmBtu})$ \\
\hline $\mathrm{CO} 2$ & N/A & $(\mathrm{b} / \mathrm{mmBtu})$ \\
\hline NOx & N/A & $(\mathrm{b} / \mathrm{mmBtu})$ \\
\hline SO2 & N/A & $(\mathrm{b} / \mathrm{mmBtu})$ \\
\hline HC & N/A & $(\mathrm{b} / \mathrm{mmBtu})$ \\
\hline PM & N/A & $(\mathrm{b} / \mathrm{mmBtu})$ \\
\hline Control Technology & N/A \\
\hline
\end{tabular}

Significant Liquid Emissions

$$
\text { N/A }
$$

Significant Solid Emissions

N/A

Noise Generated at Peak Capacity (dB)(b) Audible threshhold

\section{Regulatory Authorities and Issues}

That May Impact the Siting Process

Federal Authority

\begin{tabular}{|l|l|}
\hline \multicolumn{2}{|l|}{$\mid$} \\
\hline Clean Air Act & \\
\hline State Authority & X \\
\hline State Environmental Quality Act & \\
\hline Local Authority (County or City) & \\
\hline Air Quality Management District & \\
\hline Planning Commission (zoning) & X \\
\hline Water & \\
\hline Sewage & \\
\hline Building and Electrical & \\
\hline Occupancy & \\
\hline Not In My Back Yard (NMMBY) & X \\
\hline
\end{tabular}

Brimary Technology Reference

Johannson, T.B., et al, eds. (1993). "Renewable Energy:

Sources for Fuels and Electricity." Washington, D.C.:

Island Press.

Secondary References

(a) Miller, A. (14 June 1994). Personal Communication. National Renewable Energy Laboratory.

(b) Hubbard, H.H. and Shapherd, K.P. (June 1991).

"Aeroacoustics of Large Wind Turbines." Joumal of the

Acoutical Society of America (89:6); pp.2495-2508. 


\section{REPORT DOCUMENTATION PAGE}

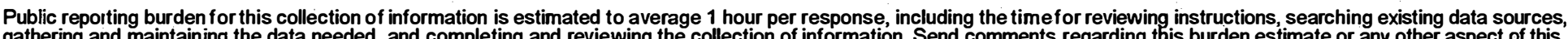

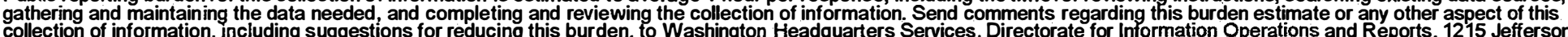

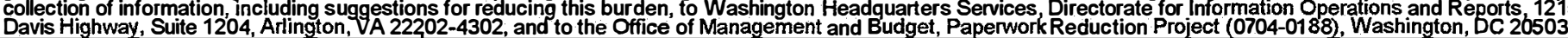
1. AGENCY USE ONLY (Leave blank)
2. REPORT
DATE.
3. REPORT TYPE AND DATES COVERED
technical report

June 1995

4. TITLE AND SUBTITLE

Distributed Utility Technology Cost, Performance, and Environmental Characteristics

5. FUNDING NUMBERS

AS819405

6. AUTHOR(S)

Y. Wan and S. Adelman

7. PERFORMING ORGANIZATION NAME(S) AND ADDRESS(ES)

National Renewable Energy Laboratory

1617 Cole Boulevard

Golden, Colorado 80401-3393

8. PERFORMING ORGANIZATION

REPORT NUMBER

TP-463-7844

U.S. Department of Energy

1000 Independence Ave., SW

10. SPONSORING/MONITORING AGENCY REPORT NUMBER

Washington, DC 20585

11. SUPPLEMENTARY NOTES

12a. DISTRIBUTION/AVAILABILITY STATEMENT

National Technical Information Service

U.S. Department of Commerce

5285 Port Royal Road

Springfield, VA 22161 12b. DISTRIBUTION CODE

UC 1320

13. ABSTRACT (Maximum 200 words)

The distributed utility (DU) is an emerging concept in which modular generation and storage technologies sited near customer loads in distribution systems and specifically targeted demand-side management programs are used to supplement conventional central station generation plants to meet customer energy service needs. Research has shown that implementation of the DU concept could provide substantial benefits to utilities. This report, funded by the U.S. Department of Energy, summarizes the cost, performance, and environmental and siting characteristics of existing and emerging modular generation and storage technologies that apply to the DU concept. It is a practical reference guide for utility planners and engineers seeking information on DU technology options.

\begin{tabular}{l|l|l}
\hline 14. SUBJECT TERMS & 15. NUMBER OF PAGES
\end{tabular} distributed utility; modular generation; energy storage; demand-side management

88

16. PRICE CODE

17. SECURITY CLASSIFICATION OF REPORT

unclassified
18. SECURITY CLASSIFICATION OF THIS PAGE unclassified
19. SECURITY CLASSIFICATION OF ABSTRACT unclassified
20. LIMITATION OF ABSTRACT

UL

NSN 7540-01-280-5500

Standard Form 298 (Rev. 2-89) Prescribed by ANSI Std. Z39-18 